\title{
Cultural Resources Survey of the DPS Outdoor Bomb and Gun Range Project, Dallas Fort Worth International Airport, Tarrant County, Texas
}

Anne Gibson

Karen Stone

Follow this and additional works at: https://scholarworks.sfasu.edu/ita

Part of the American Material Culture Commons, Archaeological Anthropology Commons, Environmental Studies Commons, Other American Studies Commons, Other Arts and Humanities Commons, Other History of Art, Architecture, and Archaeology Commons, and the United States History Commons

Tell us how this article helped you.

This Article is brought to you for free and open access by the Center for Regional Heritage Research at SFA ScholarWorks. It has been accepted for inclusion in Index of Texas Archaeology: Open Access Gray Literature from the Lone Star State by an authorized editor of SFA ScholarWorks. For more information, please contact cdsscholarworks@sfasu.edu. 


\section{Cultural Resources Survey of the DPS Outdoor Bomb and Gun Range Project, Dallas Fort Worth International Airport, Tarrant County, Texas}

\section{Creative Commons License}

\section{(c) (1) \&}

This work is licensed under a Creative Commons Attribution-NonCommercial 4.0 International License 


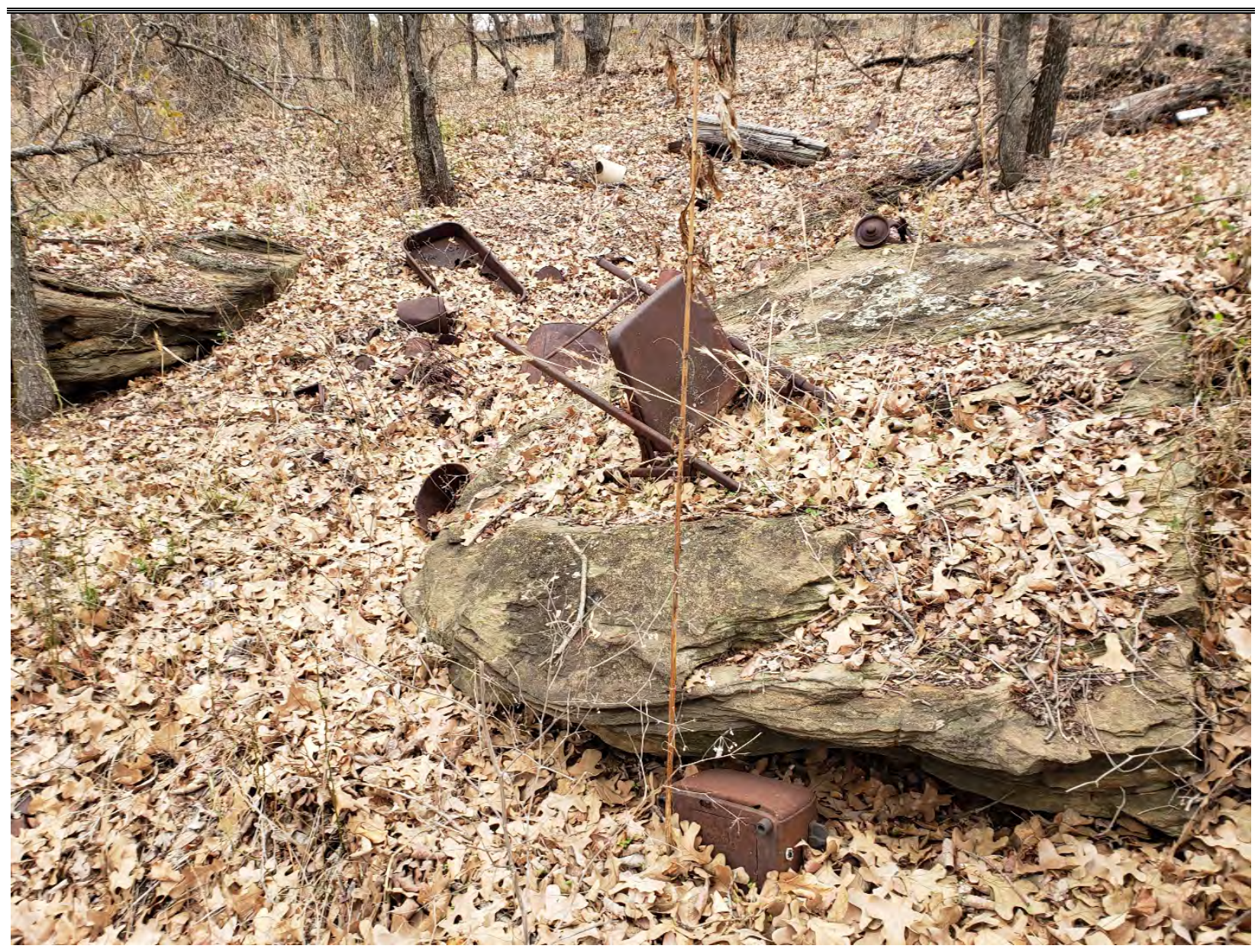

Cultural Resources Survey of the DPS Outdoor Bomb and Gun Range Project, Dallas Fort Worth International Airport, Tarrant County, Texas

Prepared for:

Texas Historical Commission

Texas Antiquities Permit \# 9161

On Behalf of:

Dallas Fort Worth International Airport

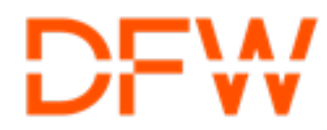

April 2020 
This page intentionally left blank 


\title{
Cultural Resources Survey of the DPS Outdoor Bomb and Gun Range Project, Dallas Fort Worth International Airport, Tarrant County, Texas
}

\author{
by \\ Anne Gibson, MA, RPA \\ Project Archeologist \\ $\&$ \\ Kevin Stone, MA, RPA \\ Principal Investigator \\ Vice President - Cultural Resources Director
}

Submitted to:

Texas Historical Commission

1511 Colorado Street

Austin, Texas 78701

Prepared by:

Integrated Environmental Solutions, LLC

610 Elm Street, Suite \#300

McKinney, Texas 75069

Cultural Resources Report

April 2020 
This page intentionally left blank 


\begin{abstract}
This report documents the substantive findings and management recommendations of a cultural resources survey conducted by Integrated Environmental Solutions, LLC (IES) for the DPS Outdoor Bomb and Gun Range project located within the Dallas Fort Worth International Airport (DFW) property in Tarrant County, Texas. The proposed project pertains to improvements of the current facility within approximately 71.8 acres located between Texas State Highway (SH) 360 and West Airfield Drive. Approval from the Federal Aviation Administration (FAA) will be required to modify the Airport Layout Plan (ALP) to reflect the permanent alterations on the DFW property. Since the ALP is considered a federal action, the project will require compliance with the National Environmental Policy Act (NEPA) and Section 106 of the National Historic Preservation Act (NHPA). Additionally, as the DFW is a political subdivision of the State of Texas, the project will be subjected to the provisions of the Antiquities Code of Texas (ACT).

The goal of the survey was to locate, identify, and assess any cultural resources that could be adversely affected by the proposed development, and to evaluate such resources for their potential eligibility for listing as a State Antiquities Landmark (SAL) and eligibility for listing in the National Register of Historic Places (NRHP).

The cultural resources inventory survey was conducted on 16 December 2019 and 08 January 2020 by Project Archeologists Anne Gibson and Thomas Chapman, and Staff Archeologist Josh McCormick. All work conformed to 13 Texas Administrative Code 26, which outlines the regulations for implementing the ACT, and was conducted under Texas Antiquities Permit No. 9161. During the survey, one previously recorded historic-age archeological site (41TR87) was revisited within the APE. Based on the lack of association with historically important individuals or events, absence of significant architectural features, the degree of prior disturbance, and lack of contextual integrity, site 41TR87 is recommended to remain not eligible for listing in the NRHP or designation as a SAL. Although multi-component site 41TR18 was partially located within the APE, the site was not evaluated during the survey. However, the results from a previous IES investigation in 2015 indicate the site should remain ineligible for NRHP listing. Project records will be permanently curated at the Center for Archeological Research (CAR) at The University of Texas at San Antonio (UTSA).

It is the recommendation of IES that the DPS Outdoor Bomb and Gun Range Project be permitted to continue without the need for further cultural resources investigations. However, if any cultural resources, other than those discussed in this report, are encountered during construction, the operators should stop construction activities in the vicinity of the inadvertent discovery, and immediately contact the project cultural resources representative to initiate coordination with the Texas Historical Commission (THC) prior to resuming construction activities.
\end{abstract}


This page intentionally left blank

DPS Outdoor Bomb and Gun Range Project Cultural Resources Survey Report
IES Project No. 03.006.081

Page ii 


\section{TABLE OF CONTENTS}

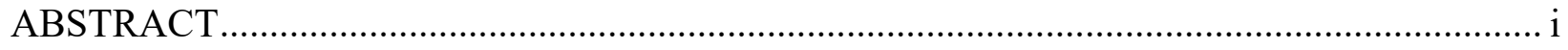

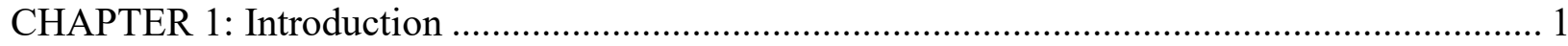

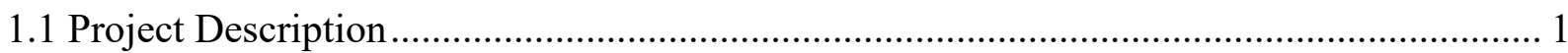

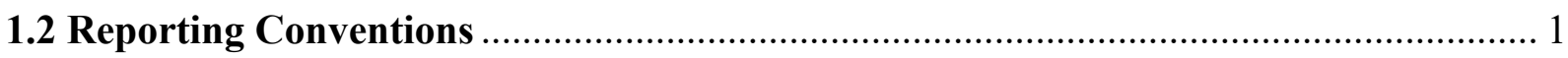

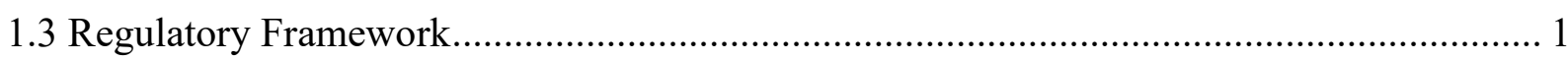

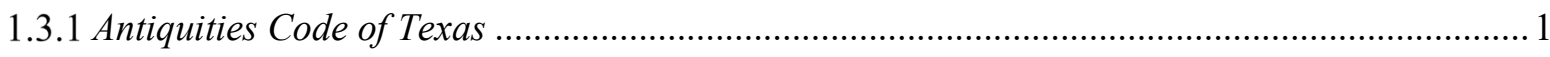

1.3.2 Section 106 of the National Historic Preservation Act ................................................................ 4

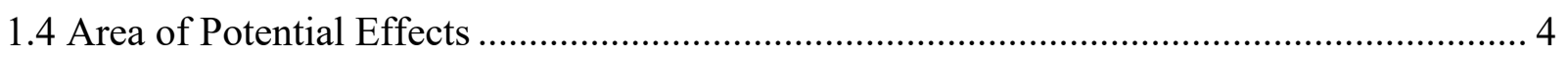

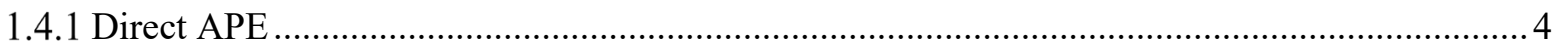

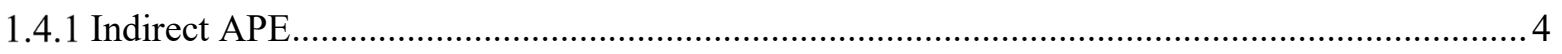

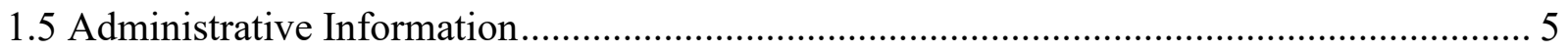

CHAPTER 2: ENVIRONMENTAL BACKGROUND ………............................................. 7

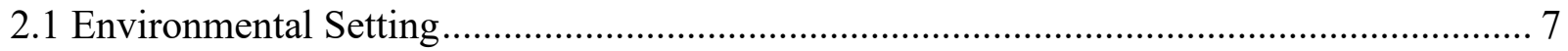

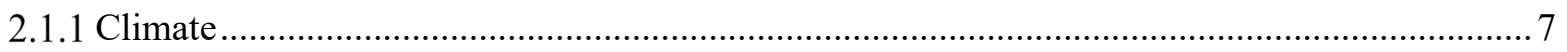

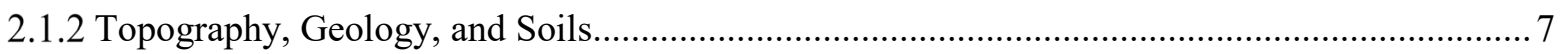

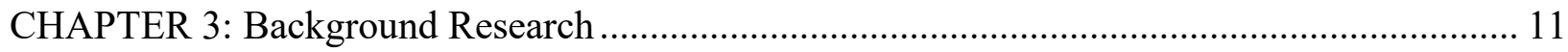

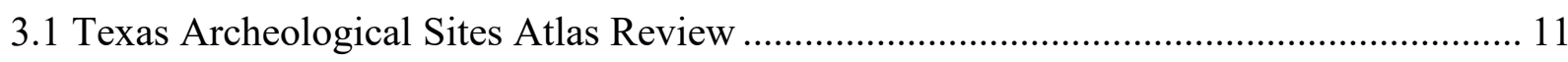

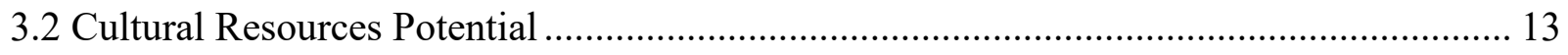

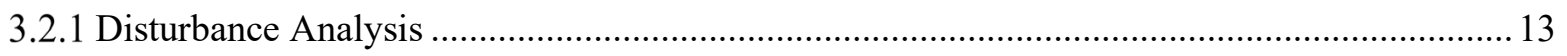

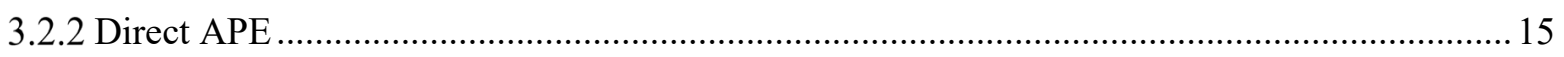

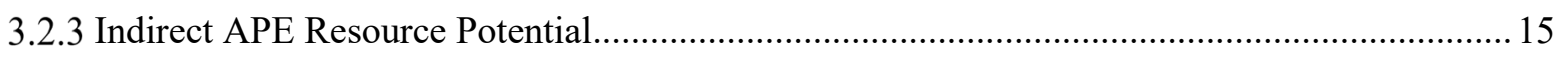

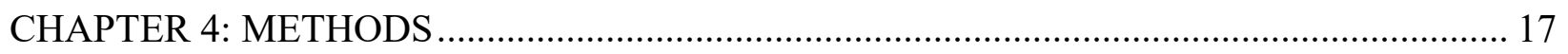

4.1 Archeological Survey Methods ..................................................................................... 17

4.1.1 Pedestrian Survey …………………………………………………………………... 17

4.1.2 Intensive Survey …………………………………………………………………. 17

4.1.3 Site Recording …………………………………………………………………..... 17

4.2 National Register Evaluation Criteria …………….................................................. 18

4.2.1 National Register Integrity Requirements...................................................................... 18

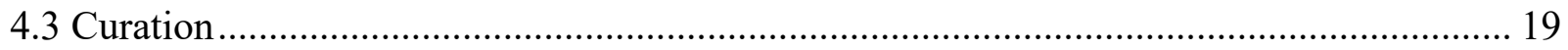

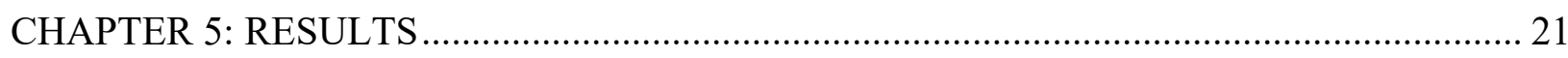

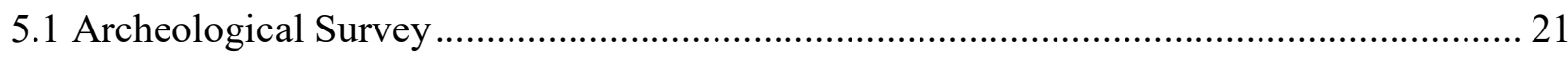

5.1.1 General Survey Observations..................................................................................... 21

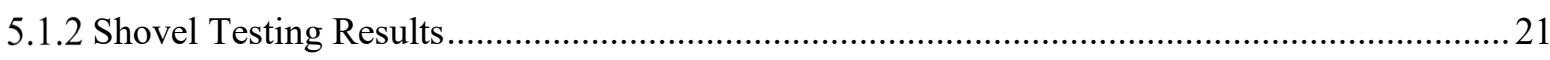




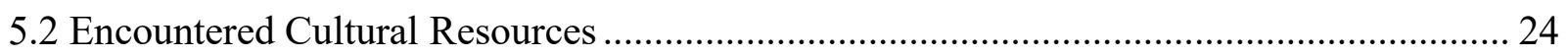

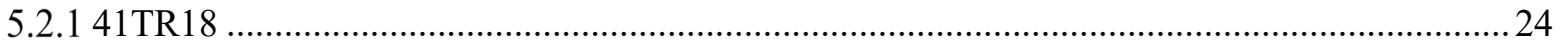

5.2.2 41TR87 …………………………………………………………………………… 24

CHAPTER 6: SUMMARY AND RECOMMENDATIONS ……………………………......... 31

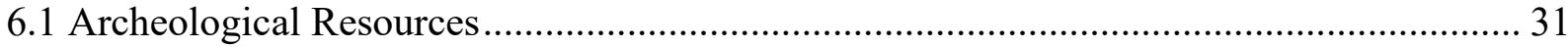

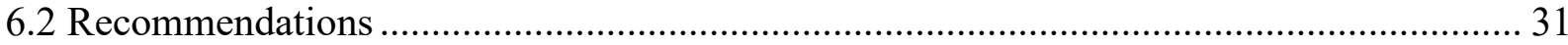

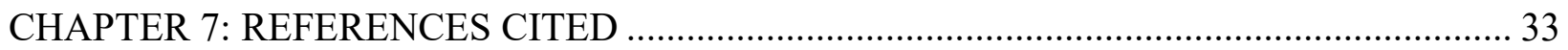

\section{LIST OF FIGURES}

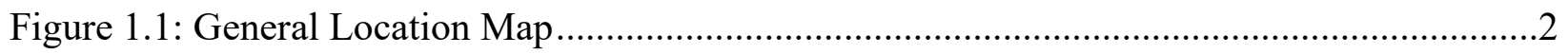

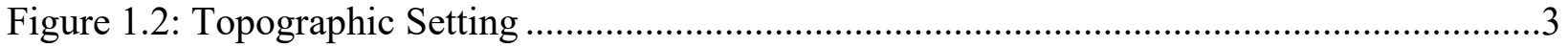

Figure 2.1: Geological Setting ...........................................................................................

Figure 2.2: Soils Located within and adjacent to the APE ……............................................... 10

Figure 3.1: Previous Investigations within 1 Mile of the APE ........................................................12

Figure 3.2: Archeological Environmental Zone Map …………................................................. 16

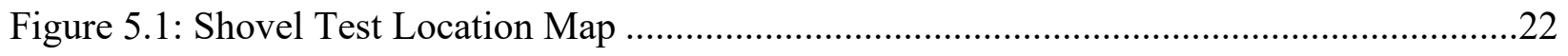

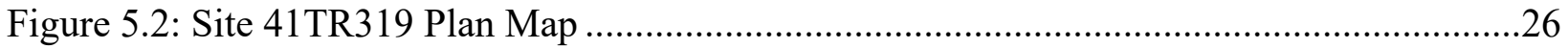

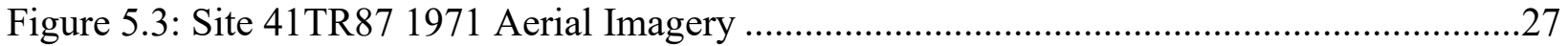

Figure 5.4: Site 41TR87 Plan Map 1973 Aerial Imagery ..........................................................28

\section{LIST OF TABLES}

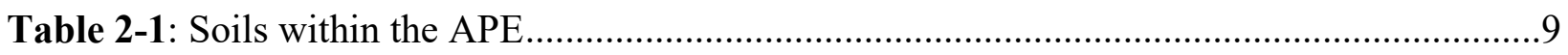

Table 3-1: Previously Conducted Archeological Surveys within the APE ..................................11

Table 3-2: Previously Recorded Archeological Sites within 1 Mile of the APE...........................11

Table 3-3: Previously Conducted Archeological Surveys within 1 Mile of the APE....................13

Table 3-4: Previously Recorded Archeological Sites within 1 Mile of the APE...........................14

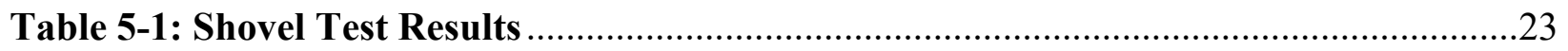

Table 6-1: Summary of NRHP/SAL Eligibility Recommendations .............................................. 31

\section{APPENDICES}

Appendix A - General Photograph Location Map and Photographs

Appendix B - Previous Agency Coordination

Appendix C - Archeological Site Location Map (Restricted Information) 


\section{CHAPTER 1: INTRODUCTION}

This report presents the results of a cultural resources survey conducted by Integrated Environmental Solutions, LLC (IES), under contract to the Dallas Fort Worth International Airport (DFW). The purpose of these investigations was to conduct an inventory of cultural resources (as defined by Code of Federal Regulations, Title 36, Section 800.4 [36 CFR 800.4]) present within the project area or Area of Potential Effects (APE). The goal of this survey was to locate, identify, and assess archeological sites, buildings, structures, or other cultural resources within the project area that may be eligible for inclusion in the National Register of Historic Places (NRHP) or designation as a State Antiquities Landmark (SAL). This investigation was conducted in accordance with 36 CFR 60.4 and Texas Administrative Code, Title 13, Chapter 26 [13 TAC 26]), which outline the regulations for implementing Section 106 of the National Historic Preservation Act of 1966 (NHPA), as amended, and the Antiquities Code of Texas (ACT), respectively. Additionally, the project aimed to evaluate identified resources for their eligibility for inclusion in the NRHP, as per Section 106 (36 CFR 800) of the NHPA or for designation as SAL under the ACT (Texas Natural Resources Code, Title 9, Chapter 191 [9 TNRC 191]) and associated state regulations (13 TAC 26). Prepared in accordance with the Council of Texas Archeologists (CTA 2002) guidelines, this report satisfies the NHPA Section 106 and the ACT requirements of the project.

A description of the proposed project area or Area of Potential Effects (APE), environmental and historical contexts, field and analytical methods, results of the investigations, and recommendations regarding the identified cultural resources are provided in this document.

\section{$\underline{1.1}$ Project Description}

As the project cultural resources consultant for the DFW, IES performed an intensive cultural resources survey for the Texas Department of Public Safety (DPS) Outdoor Bomb and Gun Range Project. The 71.8acre (ac) proposed project pertains to improvements of the existing bomb and gun range facility in the southwest quadrant of the DFW property in Tarrant County, Texas (Figures 1.1 and 1.2).

\subsection{Reporting Conventions}

Standards for archeological methods require that measurements be recorded in metric units. For this reason, while general distances and engineering specifications are described in imperial units (e.g., inch [in], foot [ft], mile [mi], ac) within this report, archeological measurements and observations are listed in metric units (e.g., centimeter $[\mathrm{cm}]$, meter $[\mathrm{m}]$, kilometer $[\mathrm{km}]$, hectare [ha]), unless historic-period artifact or architectural elements are more appropriately recorded in imperial units.

\section{$\underline{1.3} \underline{\text { Regulatory Framework }}$}

\subsubsection{Antiquities Code of Texas}

As the DFW is a political subdivision of the State of Texas, it is required to comply with the ACT. The ACT was passed in 1969 and requires that Texas Historical Commission (THC) staff review actions that have the potential to disturb historic and archeological sites on public land. Actions that require review under the ACT include any project that includes ground-disturbing activities greater than $5 \mathrm{ac}$ or involving 5,000 cubic yards of ground disturbance on land owned or controlled by a political subdivision of the state and include easements on private property. However, if the activity occurs inside a designated historic district, affects a recorded archeological site, or requires on-site investigations, the project review by the $\mathrm{THC}$ is required regardless of project size. Each cultural resource encountered was assessed for designation as a SAL under the ACT, as per 13 TAC 26. This survey was conducted under Texas Antiquities Permit No. 9161. 


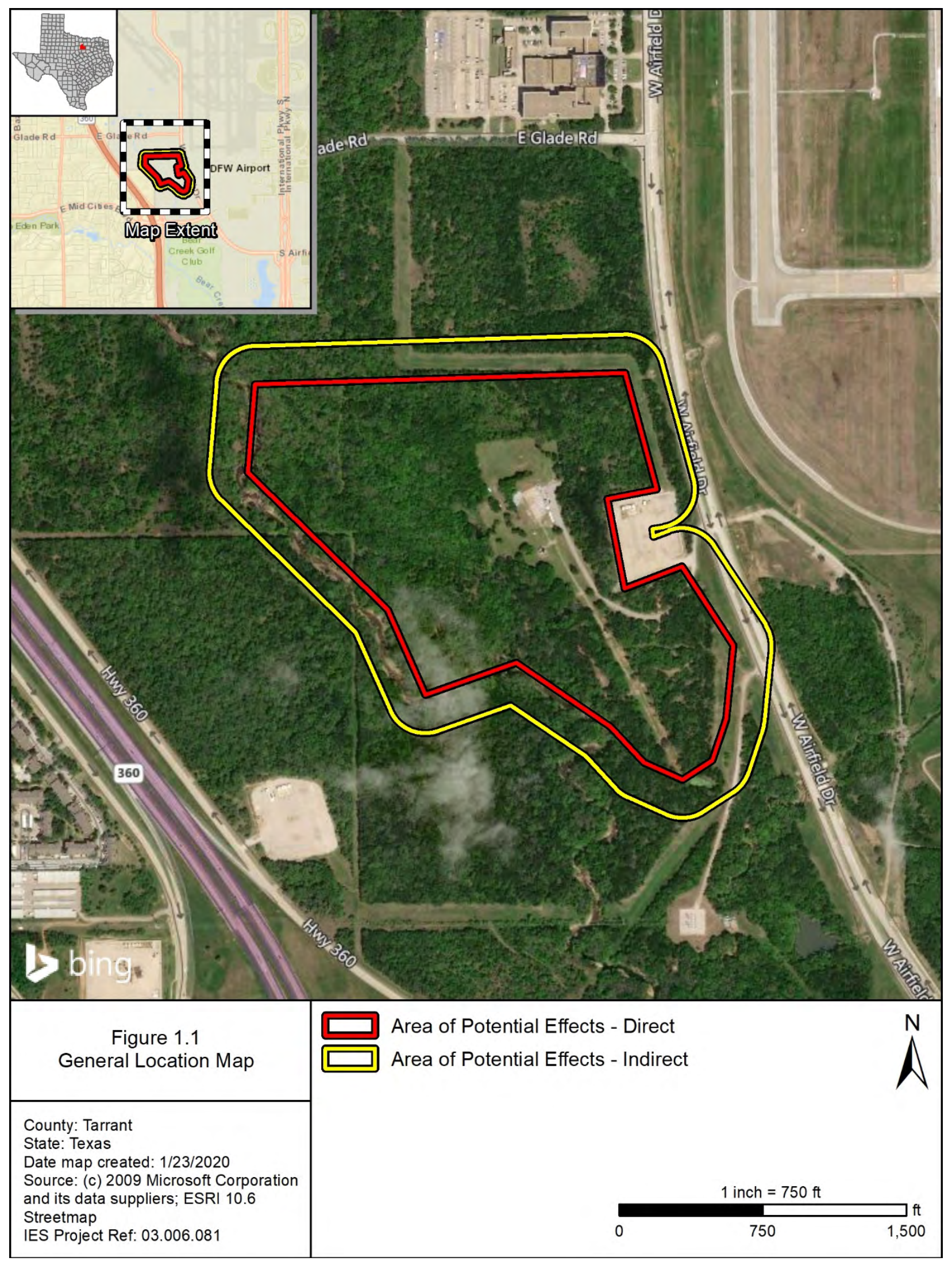




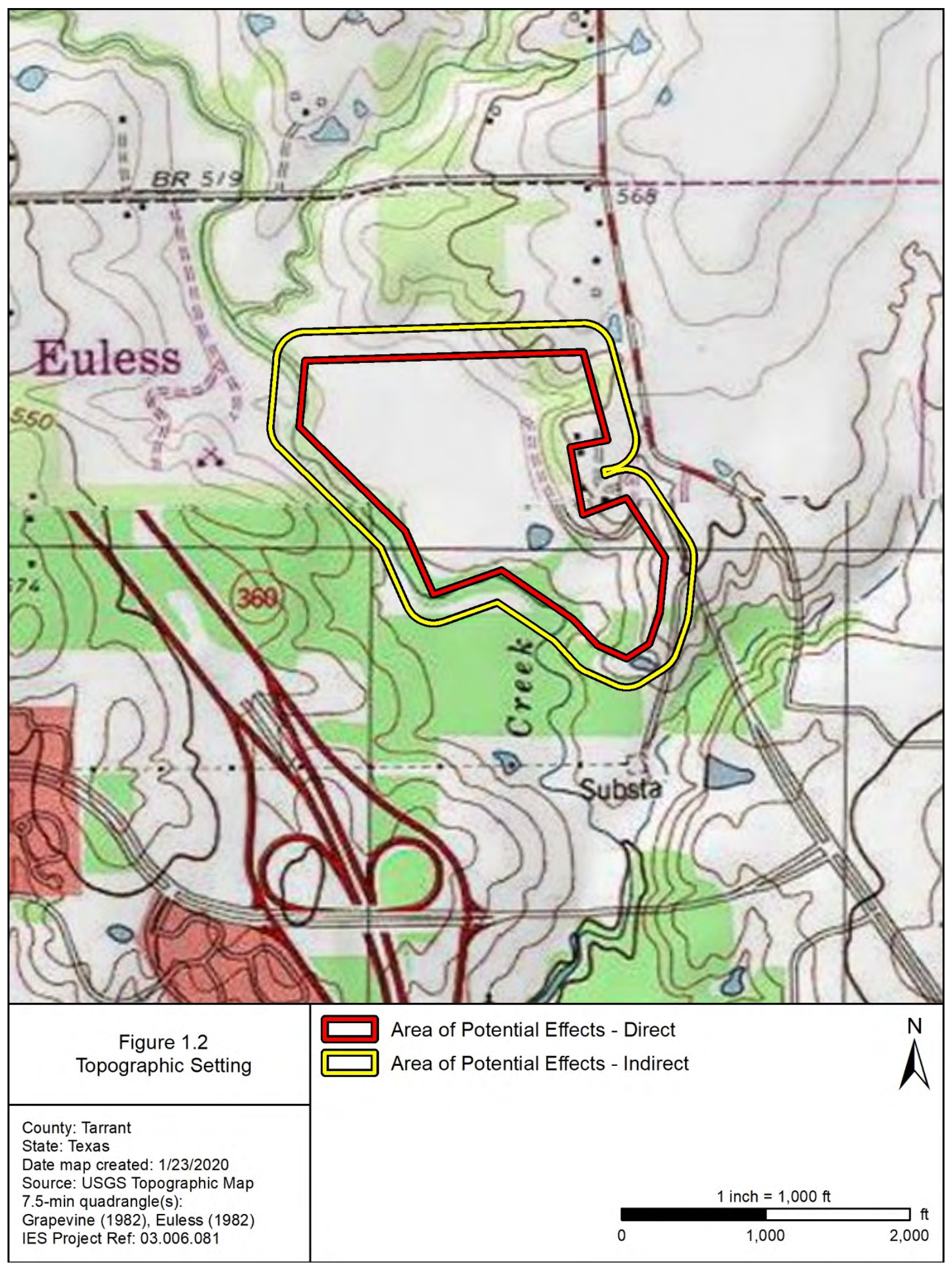

DPS Outdoor Bomb and Gun Range Project 


\subsubsection{Section 106 of the National Historic Preservation Act}

The NHPA (54 U.S. Code [USC] 306101), specifically Section 106 of the NHPA (54 USC 306108), requires the State Historic Preservation Officer (SHPO), an official appointed in each State or territory, to administer and coordinate historic preservation activities, and to review and comment on all actions licensed by the federal government that will have an effect on properties listed in the NRHP, or eligible for such listing. Federal actions include, but are not limited to, construction, rehabilitation, repair projects, demolition, licenses, permits, loans, loan guarantees, grants, and federal property transfers. Approval will be required from the Federal Aviation Administration (FAA) to modify the Airport Layout Plan (ALP) that will reflect the permanent alterations to the DFW property. Since this is considered a federal action, the project will consequently require compliance with the National Environmental Policy Act (NEPA) and Section 106 of the NHPA.

Identification, documentation, and evaluation of archeological sites shall be completed in accordance with the provisions of the Secretary of the Interior's Standards. Archeological investigations shall be performed and documented at sufficient levels to satisfy Texas SHPO and THC requirements for determining the presence of archeologically significant properties within the APE in accordance with 13 TAC 26, which outlines the regulations for implementing the ACT. The goal of the survey will be to locate, identify, and assess any cultural resources that could be adversely affected by development, and to evaluate such resources for their potential eligibility for listing as a SAL or eligibility for listing in the NRHP.

\section{$\underline{1.4}$ Area of Potential Effects}

\subsubsection{Direct APE}

The direct APE for the project encompasses approximately 71.8 ac and is located along Range Road west of West Airfield Drive. Although final project designs for the APE are not available at this time, preliminary plans call for improvements of the existing gun range. Ground disturbances associated with this development will include tree removal, general land clearing, grading, and erosion control. Depths of impacts associated with the proposed project will generally be within several $\mathrm{ft}$ of the current ground surface. However, field investigations assessed to the depth of soils capable of containing archeological deposits.

\subsubsection{Indirect $A P E$}

As the project will require approval from the FAA, an assessment of indirect effects is required to comply with the NHPA. For this project, it is anticipated that the sole indirect effect of the undertaking will be related to the visual effects of above-ground project elements, associated with the proposed improvements. To account for these above-ground elements, the indirect effects assessment area will encompass a $200-\mathrm{ft}$ buffer surrounding the APE. 


\section{$\underline{1.5}$ Administrative Information}

Sponsor: DFW

Review Agency: THC

Principal Investigator: Kevin Stone, MA, RPA

IES Project Number: 03.006.081

Days of Field Work: 16 December 2019 and 08 January 2020

Area Surveyed: 71.8 ac

Resources Recommended Eligible for NRHP Under 36 CFR 60.4: None

Resources Recommended Not Eligible for NRHP Under 36 CFR 60.4: 41TR18 and 41TR87

Resources Recommended Eligible for SAL Under 13 TAC 26: None

Resources Recommended Not Eligible for SAL Under 13 TAC 26: 41 TR18 and 41TR87

Curation Facility: No artifacts were collected. Field notes and project records will be temporarily stored at the IES office in McKinney and permanently curated at the Center for Archeological Research (CAR) at The University of Texas at San Antonio (UTSA). 
This page intentionally left blank

DPS Outdoor Bomb and Gun Range Project Cultural Resources Survey Report
IES Project No. 03.006.081

Page 6 


\section{CHAPTER 2: ENVIRONMENTAL BACKGROUND}

\subsection{Environmental Setting}

\subsubsection{Climate}

Tarrant County is located in the north-central portion of the State of Texas. This region has a humid subtropical climate and an average annual precipitation ranging from approximately 35 to 40 in (89 to 102 $\mathrm{cm}$ ). About half of the precipitation usually falls as rain between April and May, with July and August being the two driest months of the year. The subtropical region tends to have a relatively mild year-round temperature with the occasional exceedingly hot and cold snaps (Estaville and Earl 2008).

\subsubsection{Topography, Geology, and Soils}

Overall, the majority of the DFW is located within a gently rolling upland setting that is irregularly dissected by the headwaters of unnamed tributaries of surrounding streams. The periphery of the DFW property contains more dramatic topography with incised drainages and named waterways, particularly along the western, southern, and eastern limits. The transition of the gently sloping upland ridges to the low-lying Big Bear Creek valley floor correlates to a transition from the more stable, clay-rich Blackland Prairie soils to the more erosive, sandy soils of the Cross Timbers ecological region. The APE is located within the floodplain of Big Bear Creek and on the margins of an upland ridge (see Figure 1.2). Big Bear Creek forms the western boundary of the APE. Elevations within the APE range from 502 to $560 \mathrm{ft}$ (153 to $171 \mathrm{~m}$ ) above modern sea level (amsl).

The DFW property is located within an environmental interface, known as an ecotone, between the Northern Blackland Prairie and Eastern Cross Timbers ecoregions (McGowen et al. 1987). Variation among each ecoregion is a direct result of the underlying regional geology (Diggs et al. 1999). The natural divide between these two ecoregions is east of Big Bear Creek, which extends from the northwest to the southeast through the western portion of the DFW property.

The Northern Blackland Prairie is distinguished from surrounding regions by gently rolling hills and black, fine-textured soils that primarily support prairie vegetation (Griffith et al. 2007). Historical vegetation included little bluestem, big bluestem, yellow Indiangrass, and tall dropseed. Most of the native prairie has been converted to cropland, non-native pasture, and expanding urban uses around Dallas, Waco, Austin, and San Antonio. Vertisols dominate the Blackland Prairie ecoregion and consist of high clay content soils with significant shrink and swell potential (Ressel 1981).

The Eastern Cross Timbers region was historically characterized by a narrow strip of timbered, low hills that are orientated along a north-to-south axis from Tishomingo, Oklahoma to Waco, Texas (Ferring 1994; McGowan et al. 1987; TPWD 2019). This region contains numerous hills that were once heavily wooded with oak, walnut, and hickory supported by deep sandy soils (Hill 1901). Early pioneers referred to the region as the Monte Grande (Grand Forest) and later the Lower Timbers. However, due to urban expansion, agricultural development, and other modern activities, the natural vegetation has become highly fragmented, and only a few large tracts of undisturbed woodlands remain today (Griffith et al. 2007).

The APE is underlain by the Woodbine (Kwb) and Quaternary-age alluvium (Qal) geological formations (Figure 2.1; McGowen et al. 1987, USGS 2019). The Cretaceous-age Woodbine Formation is primarily sandstone and contains a small percentage of siltstone, mudstone, and clay. Weathering of the Woodbine Formation has resulted in the formation of soils with a sandy epipedon within the Cross Timbers ecoregion. The Quaternary-age alluvium deposits are comprised of clay, sand, and gravel deposited in alluvial floodplains. 


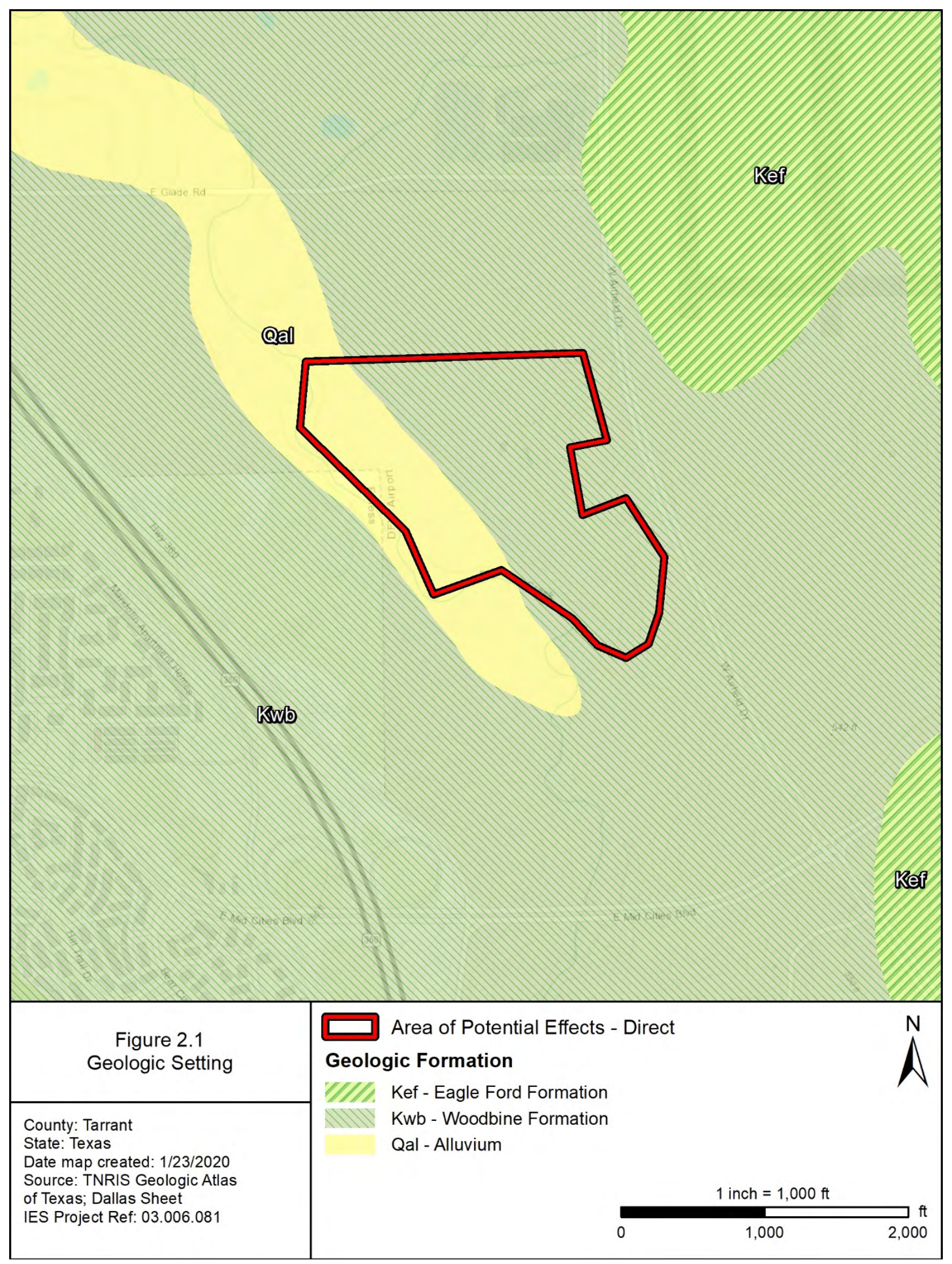

DPS Outdoor Bomb and Gun Range Project Cultural Resources Survey Report

IES Project No. 03.006.081

Page 8 
There are four mapped soil units within the APE (Figure 2.2; Table 2.1, Ressel 1981). Approximately 32.5 percent of the soils within the APE are typical of in situ development in upland settings within the Eastern Cross Timbers and Northern Blackland Prairie ecotone. The remaining 67.5 percent of the APE contains soils derived from alluvial sediment deposits along Big Bear Creek. Soil data was viewed from the U.S. Department of Agriculture (USDA) Natural Resources Conservation Service (NRCS) Web Soil Survey (USDA 2019).

Table 2-1: Soils within the APE

\begin{tabular}{|l|c||}
\hline \multicolumn{1}{|c||}{ Soil Map Unit Description } & $\begin{array}{c}\text { Percentage } \\
\text { of the APE }\end{array}$ \\
\hline \hline $\begin{array}{l}\mathbf{1 2} \text { - Birome-Aubrey-Rayex, } \mathbf{5} \text { to } \mathbf{1 5} \text { percent slopes - This component is described as gravelly fine sandy loam located on } \\
\text { ridges. Depth to a root restrictive layer or bedrock is } 20 \text { to } 40 \text { in. The natural drainage class is well drained. Typical subsoil } \\
\text { depth is } 8 \text { to } 27 \text { in }(20 \text { to } 68 \mathrm{~cm})\end{array}$ & 12.5 \\
\hline $\begin{array}{l}\mathbf{2 2} \text { - Crosstell fine sandy loam, } \mathbf{3} \text { to } \mathbf{6} \text { percent slopes - This component is described as fine sandy loam located on ridges. } \\
\text { Depth to a root restrictive layer or bedrock is } 40 \text { to } 60 \text { in. The natural drainage class is moderately well drained. Typical Bt } \\
\text { subsoil depth is } 5 \text { to } 41 \text { in }(12 \text { to } 104 \mathrm{~cm}) \text {. }\end{array}$ & 17.5 \\
\hline $\begin{array}{l}\mathbf{5 0} \text { - Navo clay loam, } \mathbf{1} \text { to } 3 \text { percent slopes - This component is described as clay loam located on ridges. Depth to a root } \\
\text { restrictive layer or bedrock is greater than } 80 \text { in. The natural drainage class is moderately well drained. Typical subsoil depth } \\
\text { is } 6 \text { to } 72 \text { in }(15 \text { to } 182 \mathrm{~cm})\end{array}$ & 2.4 \\
\hline $\begin{array}{l}\mathbf{8 3} \text { - Whitesboro loam, frequently flooded - This component is described as a loam located within floodplains. Depth to a } \\
\text { root restrictive layer or bedrock is more than } 80 \text { in. The natural drainage class is moderately well drained. Typical subsoil } \\
\text { depth is } 6 \text { to } 80 \text { in }(15 \text { to } 203 \mathrm{~cm})\end{array}$ & 67.5 \\
\hline \hline
\end{tabular}




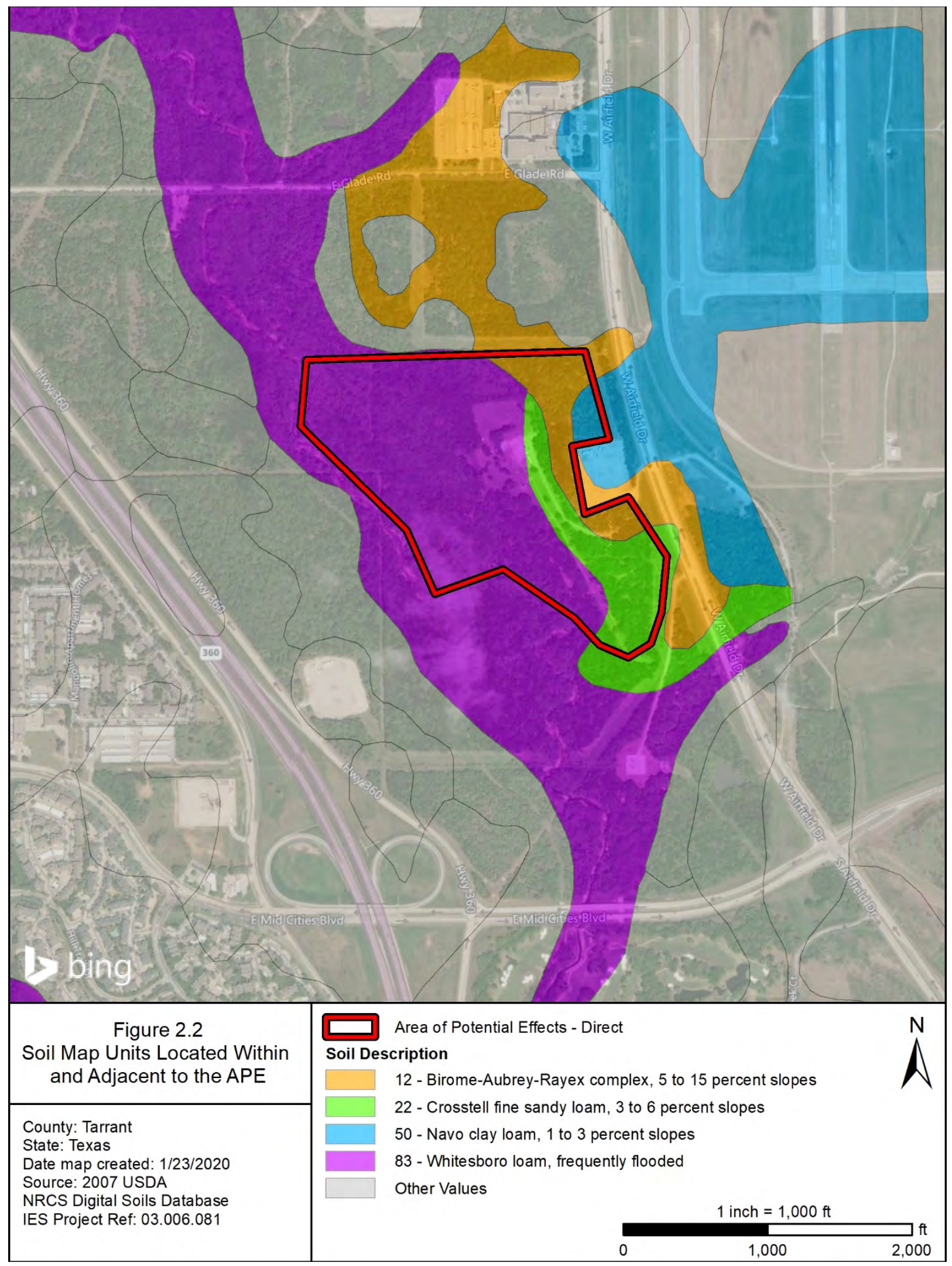

DPS Outdoor Bomb and Gun Range Project 


\section{CHAPTER 3: BACKGROUND RESEARCH}

\subsection{Texas Archeological Sites Atlas Review}

A file search within the Texas Archeological Sites Atlas (TASA) and the Texas Historic Sites Atlas (THSA) electronic databases, maintained by the THC, identified no National Register properties or districts, historical markers, or cemeteries located within the proposed APE (TASA 2019; THSA 2019). The TASA database depicted three previously conducted archeological surveys and two previously recorded archeological sites (41TR18 and 41TR87) located within the APE (Tables 3.1 and 3.2; Figure 3.1).

Table 3-1: Previously Conducted Archeological Surveys within the APE

\begin{tabular}{||c|c|c|c|c|c||}
\hline Agency & $\begin{array}{c}\text { ACT Permit } \\
\text { No. }\end{array}$ & Firm/Institution & Date & $\begin{array}{c}\text { Survey } \\
\text { Type }\end{array}$ & Location (Approximate) \\
\hline \hline $\begin{array}{c}\text { Environmental Protection Agency } \\
\text { (EPA) }\end{array}$ & No data & $\begin{array}{c}\text { Texas Department of Water } \\
\text { Resources (TDWR) }\end{array}$ & 1979 & Linear & Overlaps western portion of APE \\
\hline FAA & 4491 & ARC & 2007 & Area & Partially located in eastern APE \\
\hline DFW & 7373 & IES & 2015 & Area & Overlaps eastern portion of APE \\
\hline
\end{tabular}

Table 3-2: Previously Recorded Archeological Sites within 1 Mile of the APE

\begin{tabular}{|c|c|c|c|c|c|c|c|}
\hline $\begin{array}{c}\text { Site } \\
\text { Trinomial } \\
\end{array}$ & $\begin{array}{l}\text { Time } \\
\text { Period } \\
\end{array}$ & Site Type & Site Size & $\begin{array}{l}\text { Depth } \\
\text { Extent } \\
\text { (cm) }\end{array}$ & Cultural Materials & $\begin{array}{l}\text { Topographic } \\
\text { Setting }\end{array}$ & Reference \\
\hline 41TR18 & $\begin{array}{l}\text { Prehistoric/ } \\
\text { Historic }\end{array}$ & Lithic scatter & $120 \times 340 \mathrm{~m}$ & Unknown & $\begin{array}{c}\text { Lithic debitage; graffiti in sandstone } \\
\text { outcrop }\end{array}$ & Stream terrace & Whitsett 1979 \\
\hline 41TR87 & No data & No data & No data & No data & No data & Stream terrace & No data \\
\hline
\end{tabular}

Site 41TR18 was originally recorded in 1979 as a prehistoric quarry site atop a hill and a low-density scatter on a sandstone outcrop above Big Bear Creek. This sandstone outcrop was engraved with historic-period graffiti consisting of names and dates. The oldest legible date was 1897. In 2008, a survey was conducted under Texas Antiquities Permit No. 7373 by AR Consultants, Inc. (ARC) for a proposed Chesapeake gas pipeline that revisited the site's location. During ARC's site revisit, archeologists did not observe any lithic artifacts and noted that the prehistoric component of the site may have been destroyed by past road construction (Shelton et al. 2008). A sandstone boulder was identified on the bank of Big Bear Creek, but the face of the boulder had broken off into the creek. In the fall 2015, IES investigated part of the southeast portion of the APE as part of the Property Inventory Project - Tranche 4 under Texas Antiquities Permit No. 7373. During this survey, site 41TR18 was revisited to assess its NRHP eligibility status. IES archeologists did not encounter any of the artifacts or features that were recorded in the earlier survey (Stone et al. 2018). As a result, 41TR1 8 was determined to be ineligible for NRHP listing.

Site 41TR87 was first recorded during the Bear Creek survey conducted in 1982 (Prikryl 1990). The prehistoric component of the site was located on a terrace of Big Bear Creek and had been damaged by historic occupation. The site was revisited in 2008 by ARC as part of the survey for Chesapeake Energy. During the survey, ARC archeologists encountered a prehistoric lithic scatter and four historic-age concrete house foundations on a ridge (Shelton et al. 2008). Of the 12 shovel tests excavated within 41TR87, five were positive for cultural materials. These shovel tests contained quartzite flakes and chips observed at surface and up to $100 \mathrm{~cm}$ below surface $(\mathrm{cmbs})$. No diagnostic prehistoric artifacts were encountered. The four historic-aged concrete house foundations were mapped during the survey. Site 41TR87 was determined to be ineligible for listing on the NRHP.

The TASA records further indicated that an additional 16 archeological surveys have been previously conducted within 1 mile (mi) of the APE (Table 3.3). As a result of those previous surveys, 18 archeological sites have been documented within $1 \mathrm{mi}$ of the APE (Table 3.4). 


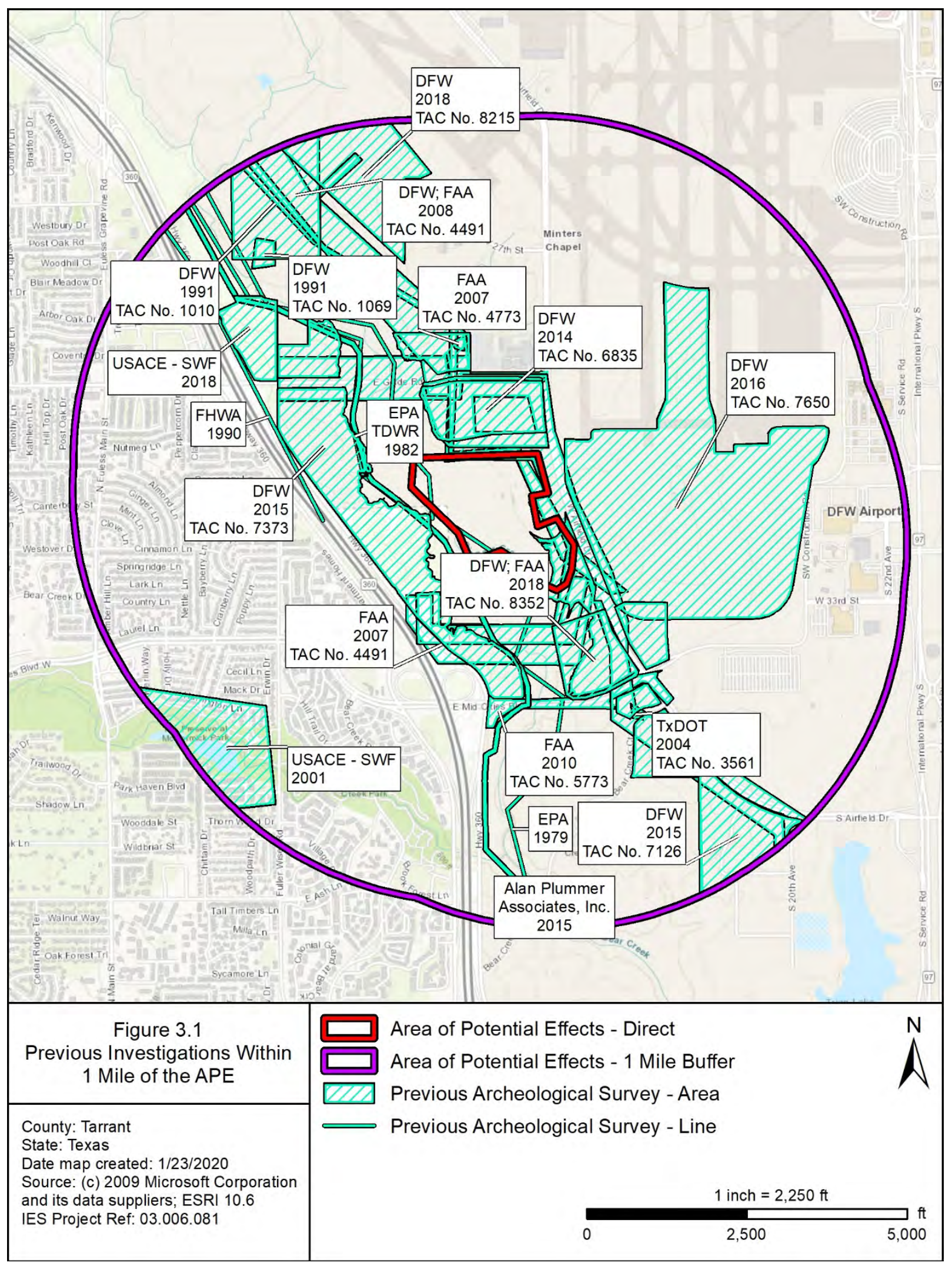

DPS Outdoor Bomb and Gun Range Project Cultural Resources Survey Report 
Table 3-3: Previously Conducted Archeological Surveys within 1 Mile of the APE

\begin{tabular}{|c|c|c|c|c|c|}
\hline Agency & $\begin{array}{c}\text { ACT Permit } \\
\text { No. } \\
\end{array}$ & Firm/Institution & Date & $\begin{array}{c}\text { Survey } \\
\text { Type }\end{array}$ & Location (Approximate) \\
\hline EPA & No data & 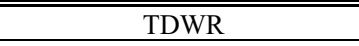 & 1982 & Linear & 0.05 mi west of APE \\
\hline FHWA & No data & $\begin{array}{l}\text { State Department of Highways } \\
\text { and Public Transportation } \\
\text { (SDHPT) }\end{array}$ & 1990 & Linear & $0.29 \mathrm{mi}$ west of APE \\
\hline DFW & 1010 & Greiner, Inc. & 1991 & Area & $0.7 \mathrm{mi}$ northwest of APE \\
\hline DFW & 1069 & Greiner, Inc. & 1991 & Testing & $0.69 \mathrm{mi}$ northwest of APE \\
\hline USACE - SWF & No data & No data & 2001 & Area & $0.75 \mathrm{mi}$ south of APE \\
\hline $\begin{array}{c}\text { Texas Department of Transportation } \\
\text { (TxDOT) }\end{array}$ & 3561 & Geo-Marine, Inc. & 2004 & Area & $\begin{array}{l}0.23 \mathrm{mi} \text { north and } 0.40 \mathrm{mi} \text { southeast } \\
\text { of APE }\end{array}$ \\
\hline FAA & 4773 & ARC & 2007 & Testing & $0.32 \mathrm{mi}$ north of APE \\
\hline FAA & 5773 & Hicks and Company & 2010 & Area & $0.32 \mathrm{mi}$ south of APE \\
\hline DFW & 6835 & IES & 2014 & Area & $0.02 \mathrm{mi}$ north of APE \\
\hline USACE & $\mathrm{n} / \mathrm{a}$ & ARC & 2015 & Area & $0.02 \mathrm{mi}$ west of APE \\
\hline DFW & 7126 & IES & 2015 & Area & $0.65 \mathrm{mi}$ southeast of APE \\
\hline DFW & 7650 & IES & 2016 & Area & 0.07 mi east of APE \\
\hline DFW & 8215 & IES & 2018 & Area & $0.58 \mathrm{mi}$ north of APE \\
\hline DFW & 8352 & IES & 2018 & Area & $0.09 \mathrm{mi}$ south of APE \\
\hline USACE - SWF & Unknown & ARC & 2018 & Area & $0.46 \mathrm{mi}$ northwest of APE \\
\hline DFW & 8777 & IES & 2019 & Area & $0.14 \mathrm{mi}$ north of $\mathrm{APE}$ \\
\hline
\end{tabular}

\subsection{Cultural Resources Potential}

In 2007 and 2008, ARC conducted intensive pedestrian surveys of 1,210 ac on the DFW property under Texas Antiquities Permit No. 4491 and published their results in the report An Archaeological Survey for Chesapeake Energy Corporation at DFW International Airport Dallas and Tarrant Counties, Texas (Shelton et al. 2008). Through this study, three environmental zones were identified within the airport that contain varying probabilities for the presence of cultural resources.

The current APE extends across the Eastern Cross Timbers (Zone 2) and Bear Creek Floodplain (Zone 3; Figure 3.2). Approximately 30 percent of the APE is situated within Zone 2. This zone is typified by a wide array of well-drained soil types ranging from those with high clay content to sandy loams located on uplands, ridges, terraces, tributary streams, and valleys. Accordingly, these soils supported a wide range of vegetation and dense stands of old growth trees during the prehistoric period. These upland soils are moderately well suited for cropland, pastureland, or urban development and the area has been well utilized for agricultural purposes since early historic settlement. As such, Zone 2 is considered to have a high potential for containing both prehistoric and historic-age archeological sites (Shelton et al. 2008).

The remaining approximate 70 percent of the APE is within the Bear Creek Floodplain (Zone 3). Zone 3 is a narrow band of alluvial floodplain adjacent to Little Bear Creek, Big Bear Creek, and Bear Creek. Because the loamy soils in this zone are frequently flooded, the land is mostly used as pasture. Cultural resources are low to nonexistent in the floodplain due to heavy modification of topsoils by agriculture over the past century and the lack of previously recorded deeply buried prehistoric sites in the Bear Creek floodplain (Shelton et al. 2008).

\subsubsection{Disturbance Analysis}

During the background review, it was determined that ground-disturbing activities have transpired within the APE related to past land use and road improvements. Historical aerial photographs indicate that the properties within and adjacent to the APE were primarily used for agricultural or ranching purposes as early as 1942 , and presumably since the late $19^{\text {th }}$ and early $20^{\text {th }}$ centuries. The majority of the APE has been cleared of woody vegetation at various points through the $20^{\text {th }}$ century, which has gradually become covered by secondary growth. 
Table 3-4: Previously Recorded Archeological Sites within 1 Mile of the APE

\begin{tabular}{|c|c|c|c|c|c|c|c|c|}
\hline $\begin{array}{c}\text { Site } \\
\text { Trinomial } \\
\end{array}$ & $\begin{array}{l}\text { Time } \\
\text { Period } \\
\end{array}$ & Site Type & $\begin{array}{l}\text { Site } \\
\text { Size } \\
\end{array}$ & $\begin{array}{c}\text { Depth } \\
\text { Extent } \\
\text { (cm) } \\
\end{array}$ & Cultural Materials & $\begin{array}{l}\text { Topographic } \\
\text { Setting }\end{array}$ & $\begin{array}{c}\text { NRHP } \\
\text { Eligibility }\end{array}$ & Reference \\
\hline $41 \mathrm{TR} 16$ & Prehistoric & Lithic scatter & $\begin{array}{l}200 \mathrm{x} \\
500 \mathrm{~m}\end{array}$ & $10-50$ & $\begin{array}{l}\text { Biface fragment, exhausted } \\
\text { core, burned rock; a mass of } \\
1920-1940 \text { refuse }\end{array}$ & Creek bank & No data & $\begin{array}{l}\text { Whitsett \& } \\
\text { Fox } 1979\end{array}$ \\
\hline $41 \mathrm{TR} 17$ & Prehistoric & Lithic scatter & $\begin{array}{r}150 \mathrm{x} \\
400 \mathrm{~m} \\
\end{array}$ & $0-20$ & Lithic debitage & Sandstone bluff & $\begin{array}{c}\text { Ineligible } \\
\text { within ROW }\end{array}$ & $\begin{array}{l}\text { Whitsett \& } \\
\text { Fox } 1979\end{array}$ \\
\hline $41 \mathrm{TR} 19$ & $\begin{array}{l}\text { Prehistoric/ } \\
\text { Historic }\end{array}$ & $\begin{array}{l}\text { Lithic scatter } \\
\text { / House site }\end{array}$ & $\begin{array}{c}400 \times 75 \\
\mathrm{~m}\end{array}$ & $0-10$ & $\begin{array}{c}\text { Lithic debitage, burned rock, } \\
\text { brick, cistern, and domestic } \\
\text { trash }\end{array}$ & Upland terrace & Ineligible & $\begin{array}{l}\text { Whitsett } \\
\text { \&Fox } 1979\end{array}$ \\
\hline 41TR20 & Prehistoric & Lithic scatter & $\begin{array}{c}200 \times 75 \\
\mathrm{~m}\end{array}$ & 20 & $\begin{array}{c}\text { Lithic debitage, thinned } \\
\text { biface fragment }\end{array}$ & Low hill & Undetermined & $\begin{array}{l}\text { Whitsett \& } \\
\text { Fox } 1979\end{array}$ \\
\hline $41 \mathrm{TR} 21$ & $\begin{array}{l}\text { Prehistoric/ } \\
\text { Historic }\end{array}$ & Lithic scatter & $100 \mathrm{~m}$ & 50 & $\begin{array}{l}\text { Bifacial cores }(n=4) \text {, stem } \\
\text { dart points }(n=3) \text {, thinned } \\
\text { biface, ironstone sherd }\end{array}$ & Stream terrace & No data & $\begin{array}{l}\text { Whitsett } \\
1979\end{array}$ \\
\hline 41TR63 & Prehistoric & $\begin{array}{l}\text { Quarry and } \\
\text { chipping } \\
\text { station } \\
\end{array}$ & $\begin{array}{l}210 \mathrm{x} \\
110 \mathrm{~m}\end{array}$ & No data & No data & Upland terrace & No data & $\begin{array}{c}\text { Lorrain } \\
1973\end{array}$ \\
\hline $41 \mathrm{TR} 79$ & $\begin{array}{l}\text { Prehistoric/ } \\
\text { Historic }\end{array}$ & $\begin{array}{c}\text { Open } \\
\text { campsite/ } \\
\text { Historic } \\
\text { residence }\end{array}$ & $\begin{array}{l}200 \mathrm{x} \\
170 \mathrm{~m}\end{array}$ & 10 & $\begin{array}{l}\text { Lithic chipping debris and } \\
\text { cores, glass, crockery, } \\
\text { whiteware }\end{array}$ & Upland knoll & No data & $\begin{array}{c}\text { Prikryl } \\
1982\end{array}$ \\
\hline $41 \mathrm{TR} 80$ & No data & No data & No data & No data & No data & No data & No data & No data \\
\hline $41 \mathrm{TR} 82$ & $\begin{array}{c}\text { Prehistoric/ } \\
\text { Historic }\end{array}$ & $\begin{array}{l}\text { Artifact } \\
\text { scatter }\end{array}$ & $\begin{array}{c}165 \times 75 \\
\mathrm{~m}\end{array}$ & $0-10$ & $\begin{array}{c}\text { burned rock, debitage, } \\
\text { whiteware ceramics, glass }\end{array}$ & Upland terrace & Ineligible & $\begin{array}{c}\text { Prikryl } \\
1982\end{array}$ \\
\hline $41 \mathrm{TR} 83$ & No data & No data & No data & No data & No data & Stream terrace & No data & No data \\
\hline $41 \mathrm{TR} 127$ & Historic & Farmstead & $76 \times 8 \mathrm{~m}$ & Surface & $\begin{array}{c}\text { Lithic debitage, cobbles and } \\
\text { fire cracked rock }\end{array}$ & Upland terrace & Ineligible & $\begin{array}{c}\text { Eastman } \\
1991 \\
\end{array}$ \\
\hline $41 \mathrm{TR} 218$ & Historic & $\begin{array}{l}\text { Artifact } \\
\text { Scatter }\end{array}$ & $\begin{array}{c}30 \times 50 \\
\mathrm{~m}\end{array}$ & 25 & $\begin{array}{l}\text { Nails, bolts, glass, and other } \\
\text { 20th century debris }\end{array}$ & Upland terrace & Ineligible & $\begin{array}{c}\text { Shelton } \\
2008\end{array}$ \\
\hline $41 \mathrm{TR} 219$ & Prehistoric & Lithic scatter & $\begin{array}{c}120 \times 60 \\
\mathrm{~m}\end{array}$ & $20-30$ & Lithic debitage & Upland terrace & Ineligible & $\begin{array}{c}\text { Shelton } \\
2007\end{array}$ \\
\hline $41 \mathrm{TR} 273$ & $\begin{array}{l}\text { Prehistoric, } \\
\text { Historic }\end{array}$ & $\begin{array}{l}\text { Lithic scatter, } \\
\text { trash midden }\end{array}$ & $\begin{array}{l}165 \mathrm{x} \\
175 \mathrm{~m}\end{array}$ & $0-20$ & $\begin{array}{l}\text { Glass bottles, jars, } \\
\text { corrugated tin, rubber, } \\
\text { milled lumber, tires, church- } \\
\text { key opened cans, hog fence, } \\
\text { scrap metal; bifaces }(n=2), \\
\text { tested cobbles }(n=6), \text { chunks } \\
(n=10) \text {, and debitage }(n=26)\end{array}$ & Upland & Ineligible & $\begin{array}{l}\text { Stone \& } \\
\text { Hamilton } \\
2015\end{array}$ \\
\hline $41 \mathrm{TR} 294$ & Historic & $\begin{array}{l}\text { Surface } \\
\text { scatter }\end{array}$ & $\begin{array}{c}15 \times 23 \\
\mathrm{~m}\end{array}$ & Surface & $\begin{array}{l}\text { Glass bottles, cans, ceramic } \\
\text { sherds, building materials }\end{array}$ & Upland & Ineligible & $\begin{array}{c}\text { Gibson } \\
2015 \\
\end{array}$ \\
\hline $41 \mathrm{TR} 295$ & Historic & $\begin{array}{l}\text { Historic } \\
\text { scatter }\end{array}$ & $\begin{array}{l}60 \mathrm{x} \\
50 \mathrm{ft} \\
\end{array}$ & Surface & Building materials & Upland & Ineligible & $\begin{array}{c}\text { Gibson } \\
2015 \\
\end{array}$ \\
\hline $41 \mathrm{TR} 311$ & Historic & $\begin{array}{l}\text { Historic } \\
\text { scatter }\end{array}$ & $\begin{array}{l}280 \mathrm{x} \\
30 \mathrm{~m}\end{array}$ & $0-20$ & $\begin{array}{c}\text { Ceramic, glass, utensils, } \\
\text { oyster shells }\end{array}$ & Upland & Ineligible & $\begin{array}{c}\text { Goodmaste } \\
\text { r \& Gibson } \\
2018\end{array}$ \\
\hline $41 \mathrm{TR} 312$ & Historic & Farmstead & $\begin{array}{l}75 \mathrm{x} \\
77 \mathrm{~m}\end{array}$ & $0-30$ & $\begin{array}{l}\text { Bricks, concrete chunks, } \\
\text { nail, ceramic, glass, bone } \\
\text { fragment }\end{array}$ & Upland & Ineligible & $\begin{array}{c}\text { Gibson \& } \\
\text { Chapman } \\
2018\end{array}$ \\
\hline
\end{tabular}

In the 1950s, four buildings and an associated road were constructed within or adjacent to the direct APE. During the late 1960s and early 1970s, land was purchased by the cities of Dallas and Fort Worth for the construction of DFW. Between 1970 and 1979, all existing buildings and structures within the APE were demolished. By 1979, the DPS outdoor firing range and Range Road had been constructed off of the newly

built West Airfield Drive. A subsurface pipeline was installed through the western half of the APE in the 1980s. In 2008, a pad site and natural gas pipeline were installed directly adjacent to the eastern APE boundary. 


\subsubsection{Direct $A P E$}

\subsubsection{Prehistoric Archeological Potential}

The Texas Department of Transportation (TxDOT) Potential Archeological Liability Map (PALM) for Tarrant County indicates that the majority of the APE along Big Bear Creek contains a high potential for containing shallow and deeply buried cultural resources within a reasonable context. The remaining portion of the APE features a moderate to low potential for containing shallow and deeply buried cultural resources. These portions of the APE are located in the western half of the APE outside of the Bear Creek valley. However, through data provided from past archeological studies and an assessment of historical land use within the APE, it can be assumed the majority of the APE has been exposed to shallow subsurface disturbances. For these reasons, the portion of the APE near Big Bear Creek was considered as having a moderate potential and the remainder of the APE a low to negligible potential for containing shallowly buried prehistoric cultural resources.

In 1997, an archeological survey was conducted by Geoarch Consultants, Inc. for a proposed Trinity River Authority (TRA) pipeline along Bear Creek. As part of the survey, 26 backhoe trenches were excavated to assess for impacts to deeply buried archeological sites along Bear Creek. Through these investigations and subsequent surveys, no deeply buried archeological sites have been encountered. Subsequently, it appears that there is a low probability for deeply buried sites within the Bear Creek floodplain.

Although the PALM presents the ridge in the western APE as having a low potential for intact deeply buried prehistoric resources, previous archeological investigations indicate a subsurface scatter of lithic debitage was present on the ridge as part of site 41TR87. Archeologists encountered lithic debitage at depths of up to $100 \mathrm{cmbs}$. However, the majority of the site was destroyed by the construction of a pad site. In consideration of this, the ridge contains a low probability for containing intact deeply buried cultural deposits.

\subsubsection{Historic Period Archeological Potential}

Historic-period resources within North-Central Texas are primarily related to farmsteads, houses, and associated outbuildings and structures that date from the mid- $19^{\text {th }}$ to the mid- $20^{\text {th }}$ centuries. Typically, these types of resources are located along old roadways, but also can be located along railroads, streams, and open pastures. Although determining the presence of the earliest buildings and structures is problematic, maps depicting these features are available post- 1895 .

A 1956 aerial photograph depicts a house, one of four houses west of West Airfield Drive, within the APE. This house appears to have been constructed between 1953 and 1956 in the northernmost lot of a small housing division. After properties were bought for the DFW in the late 1960s or early 1970s, all standing structures within and surrounding the APE were demolished between 1970 and 1979. In 2008, ARC recorded the foundation of the northern house, Feature D, within site 41TR87. Recent aerial photographs indicate the area of Feature D was not directly impacted by the installation of a pad site and subsurface pipeline. As such, there is a moderate potential for encountering the historic-age component of site 41TR87 within the APE. No other buildings or structures were depicted in historical maps or aerial photographs.

\subsubsection{Indirect APE Resource Potential}

Based on a review of historic maps and aerial photographs, no historic-age standing structures or architectural resources are present within the indirect APE. 


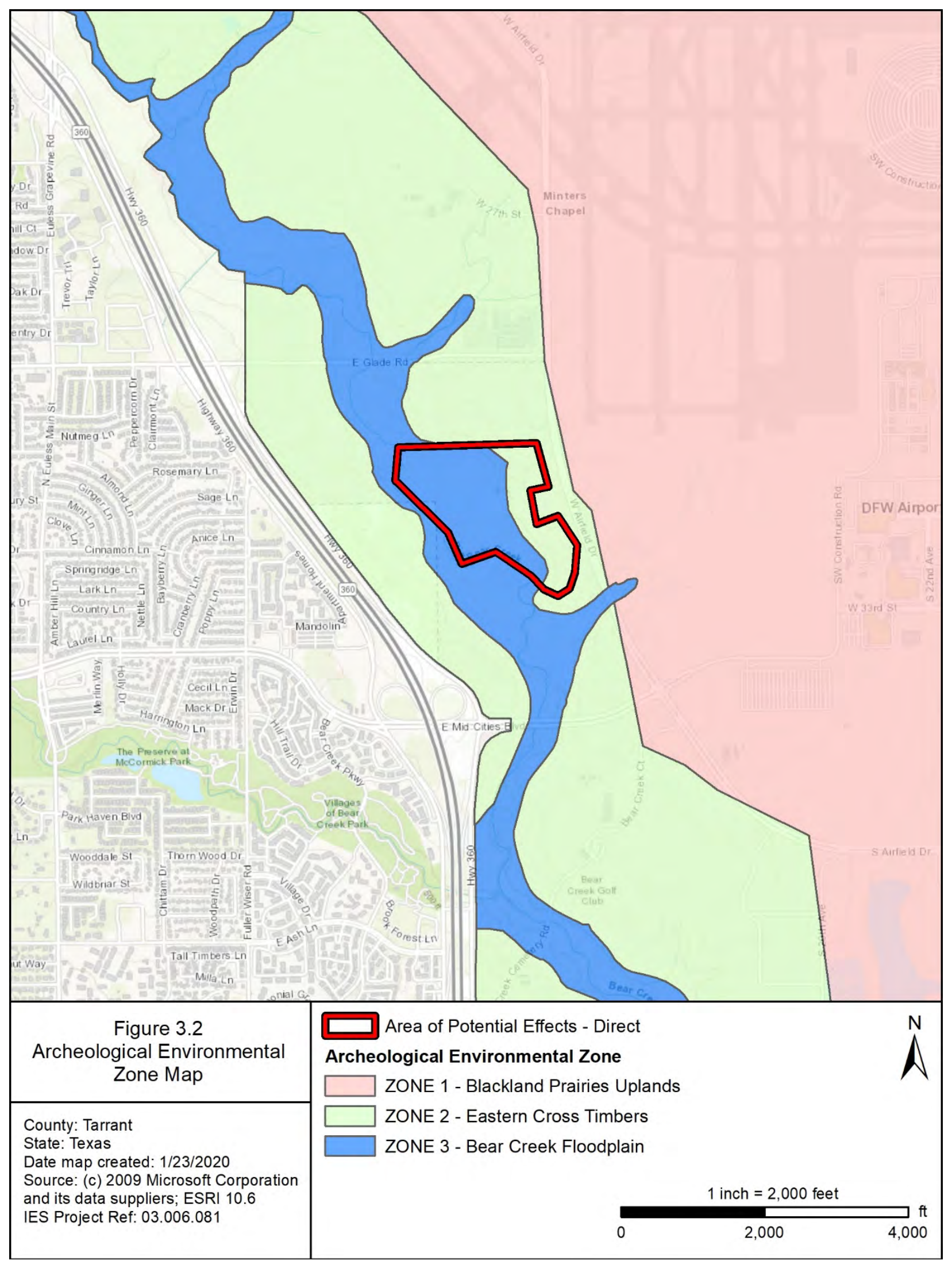

DPS Outdoor Bomb and Gun Range Project 


\section{CHAPTER 4: METHODS}

The methods utilized during this survey satisfy the archeological survey standards for field investigations recommended by the CTA (CTA 2002), as approved by the THC. Components of the survey included background research, pedestrian reconnaissance survey, and intensive survey. Prior to fieldwork, the IES staff conducted historical and archeological records reviews to determine the locations of previously recorded resources within the APE and within a 1-mi (1.6- km) radius of the direct APE (see Section 3.1). IES staff also reviewed ecological, geologic, and soils data, historical and modern topographic maps, and aerial photographs of the APE.

\subsection{Archeological Survey Methods}

\subsubsection{Pedestrian Survey}

This cultural resources survey consisted of a pedestrian survey augmented by the excavation of systematically-placed shovel tests. The pedestrian reconnaissance survey consisted of visual examination of the ground surface and existing subsurface exposures for evidence of archeological sites within the APE. The pedestrian survey consisted of a multiple transect scheme, which was implemented across the APE with a focus on areas determined during the background review to contain a high probability for the occurrence of cultural resources. Transects were spaced in 30-m intervals orientated in a generally east-towest orientation. Areas displaying high levels of disturbance were photographed to document the lack of potential for intact archeological deposits. Other documentation methods included narrative notes, maps, and shovel test records.

\subsubsection{Intensive Survey}

In previously unsurveyed and undisturbed portions of the APE with the potential for preserving archeological materials, shovel tests were excavated to $80 \mathrm{cmbs}$ or to the top of culturally sterile deposits, typically to the argillic (Bt) or calcic (Bk) subsoil horizon. Shovel tests were at least $30 \mathrm{~cm}$ in diameter and were hand-excavated in levels not exceeding $20 \mathrm{~cm}$ in thickness. Excavated soil was screened using 0.25in hardware cloth to facilitate the recovery of buried cultural materials. When high clay content soils were encountered and could not be efficiently screened, material was manually troweled and inspected for cultural deposits. The physical properties of each natural soil stratum were recorded, and investigators documented the results of each test on standardized shovel test forms. All shovel test locations were recorded and plotted using Garmin or Trimble GeoXT handheld Global Positioning System (GPS) units.

\subsubsection{Site Recording}

An archeological site is typically considered to be a spatially discrete area containing cultural resources. The recognition of a "site" is therefore contingent on content and extent. Content may refer to artifacts or cultural features encountered in surface or subsurface contexts, architectural elements, or other manifestations of past human activity. The extent of a site is based on the vertical and horizontal spatial arrangement of these cultural remains. For surficial materials, a site is defined as five or more artifacts of at least two different materials or functional classes located within the same vicinity (typically a $400 \mathrm{~m}^{2}$; $[0.1-\mathrm{ac}]$ area) or at least one cultural feature. The extent of the surface artifacts and cultural features are then defined as the site boundary. When artifacts or features are encountered in buried contexts, a site is defined within the extent of the culturally positive excavations. In cases where an excavated survey sampling location (i.e., shovel test) yields cultural materials, additional delineation excavations are conducted to define the boundary of the site. The spatial extent of the site is defined within the extent of positive excavations and surface artifacts or features when both are present. In addition, archival research can also be used to define the limits of some historic-period archeological sites.

Cultural remains, meeting these criteria, are designated as a site, recorded on a Texas Archeological Site Data Form, and submitted to the Texas Archeological Research Laboratory (TARL) to be included in the 
TASA database. Conversely, discovery of cultural materials that do not meet these criteria are considered isolated occurrences of past human activity and are simply documented by location and content. Modern materials and features (i.e., less than 50 years old) are not considered sites, with only location and content noted during the survey. Depending on depositional integrity and cultural content, archeological sites can be eligible for inclusion in the NRHP or for designation as SALs. Cultural isolates and modern features are not eligible for inclusion in the NRHP or for designation as SALs because of their failure to meet the site definition and their inability to contribute important information to the understanding of history or prehistory.

\subsection{National Register Evaluation Criteria}

The assessment of significance of a cultural resource is based on federal regulations and guidelines. The regulatory criteria for evaluating resources for inclusion in the National Register are codified under the authority of the NHPA of 1966, as amended (36 CFR 60.4 [a-d]), and the Advisory Council on Historic Preservation (ACHP) has also set forth guidelines to use in determining site eligibility. Federal regulations indicate that " $\mathrm{t}] \mathrm{h}$ he term 'eligible for inclusion in the National Register' includes both properties formally determined as such by the Secretary of the Interior and all other properties that meet National Register listing criteria" (36 CFR 800.2[e]). Based on ACHP guidelines, any cultural resource that is included in or eligible for inclusion in the National Register is a historic property.

Subsequent to the identification of relevant historical themes and related research questions, four criteria for eligibility are applied. The regulations provide that the quality of significance in American history, architecture, archeology, engineering, and culture is present in districts, sites, buildings, structures, and objects that possess integrity of location, design, setting, material, workmanship, feeling, and association and:

Criterion A: that are associated with events that have made a significant contribution to the broad patterns of our history; or

Criterion B: that are association with the lives of persons significant in our past; or

Criterion C: that embody the distinctive characteristics of a type, period, or method of construction, or that represent the work of a master, or that possess high artistic values, or that represent a significant and distinguishable entity whose components may lack individual distinction; or

Criterion D: that have yielded, or may be likely to yield, information important in prehistory or history [36 CFR $60.4(\mathrm{a}-\mathrm{d})]$.

The principal objective is to determine whether a cultural resource possesses the potential to contribute to one or more of the above-defined criteria. Adequate information regarding site function, context, and chronological placement from both archeological and, if appropriate, historical perspectives is essential for cultural resources investigations. Because research questions vary as a result of geography, temporal period, and project design, determination of site context and chronological placement of cultural resources is a particularly important objective during the inventory and evaluation processes. Criterion $\mathrm{D}$ is generally associated with prehistoric, but also historic-era, archeological sites. Criteria A, B, and C typically reflect association with historic-era resources, rarely with prehistoric sites. The objective of the current project was to locate and define both the horizontal and vertical extents of any cultural resources, document and describe those resources, and then, when adequate data were present, evaluate each for NRHP eligibility.

\subsubsection{National Register Integrity Requirements}

Overall, the property must also retain the defining features and characteristics that were present during the property's period of significance to be considered eligible for NRHP listing. The NRHP defines seven aspects of integrity as: location, setting, design, materials, workmanship, feeling, and association. 
Resources that may be considered eligible under Criteria A and B are those associated with events or broad patterns in history or persons affiliated with those activities. Although it is necessary to consider the architectural and physical integrity for resources evaluated under Criteria A or B, attributes of historical integrity will be more highly valued for these criteria. Thus, the most important aspects of integrity for evaluating resources under these criteria are location, feeling, and association.

Properties eligible for the NRHP under Criterion $\mathrm{C}$ derive significance from the physical qualities of their design, construction, and/or craftsmanship, which includes elements like engineering or architecture. A property significant under Criterion $\mathrm{C}$ is one that clearly represents a noteworthy example of a defined property type, dates from a period of significance of one or more historic context(s) and exhibits the character-defining features of its property type. Therefore, a property must retain a high degree of physical integrity, as well as having relation to the historic context.

For a cultural resource to be eligible under Criterion D, the property must have the potential to answer questions, in part or full, about human history that can only be answered by the actual physical material of the resource and the information to be obtained must also be important to understanding the past. The most common cultural resource that are listed under this criterion are archeological sites; however, nonarcheological resources can also be eligible under Criterion D.

\section{$\underline{4.3}$ Curation}

No artifacts were collected during the survey. Representative samples and diagnostic artifacts were photographed. Records, correspondence, field notes, forms, and other documentation will be included in the curation package. These documents and photographs will be organized and catalogued according to CAR curation standards and submitted for curation. All field-generated documents will be temporarily stored at the IES office and permanently curated at UTSA CAR. 
This page intentionally left blank

DPS Outdoor Bomb and Gun Range Project Cultural Resources Survey Report
IES Project No. 03.006.081

Page 20 


\section{CHAPTER 5: RESULTS}

During this survey, the direct APE was subjected to reconnaissance survey transects and a systematic intensive survey. Pedestrian reconnaissance survey was conducted across the entire APE to determine the extent of prior ground disturbances and assess the likelihood of encountering cultural resources. Ground surface visibility was highly variable and irregular across the APE, ranging from 0 percent in undisturbed areas and heavily wooded areas to 100 percent in areas of vegetation removal. Intensive survey with systematic shovel test sampling was also conducted within previously undisturbed portions of the APE during this survey. During this survey, one previously recorded archeological site (41TR87) was revisited.

\subsection{Archeological Survey}

\subsubsection{General Survey Observations}

The APE generally featured wooded growth with an open understory and occasional dense undergrowth near roads, bodies of water, and fence lines (Appendix A, Photographs 1 through 22). The ridge in the eastern half of the APE contained thin, wooded growth of oak and cedar with ground cover of short grass species and leaf litter (see Appendix A, Photographs 7 through 9). Exposed bedrock was observed at lower elevations of the ridge slope (Appendix A, Photograph 23). A deeply incised tributary was encountered north of the ridge in the northeast quadrant of the APE (see Appendix A, Photographs 10 through 13).

The most significant disturbance observed within the APE was the central gun range facility, which included multiple buildings, interior roads, a paved pavilion area, a parking lot, and areas for training with firearms and explosives (Appendix A, Photographs 25 through 35). A large earthen mound was situated between the northern training range and the southern portion of the facility (see Appendix A, Photographs $\mathbf{2 8 , 3 1}$, and 35). In the northwest corner of the range, IES archeologists encountered multiple recently excavated holes (Appendix A, Photograph 36). No cultural materials were identified in these holes.

The eastern half of the APE contained an obstacle course, which consisted of multiple dirt trails, trail markers, and obstacle stations containing wooden pole or lumber structures (Appendix A, Photographs 37 through 42). This area also featured a well pad site north of Range Road (Appendix A, Photographs 43 and 44). Within the APE, an earthen berm was observed around the pad site and erosion control measures (rock rip-rap, silt screen) near the southwest corner (Appendix A, Photographs 45 and 46). Fill from initial construction of the pad site was identified near the rock rip-rap (Appendix A, Photograph 47). These areas were determined to contain a negligible potential for subsurface cultural deposits. Individual shovel tests within these sections were offset to maximize the potential for sampling within less disturbed areas. Subsequently, more extensively disturbed areas were visually assessed and photographed during the pedestrian survey.

\subsubsection{Shovel Testing Results}

During this survey, 42 shovel tests were excavated within the 71.8 ac APE (Figure 5.1). Shovel test sampling was conducted within portions of the APE not previously surveyed by IES and with the potential to contain buried archeological deposits. In addition to the 42 excavated shovel tests for the current project, six previously excavated shovel tests were located within the southeast quadrant of the APE and were excavated by IES during prior DFW-sponsored projects. Subsequently shovel testing densities for the project exceeded CTA and THC standards of one shovel test per 2 ac. Previously disturbed areas were visually assessed and photographed during the pedestrian transect survey. No subsurface artifacts were observed within shovel tests. 


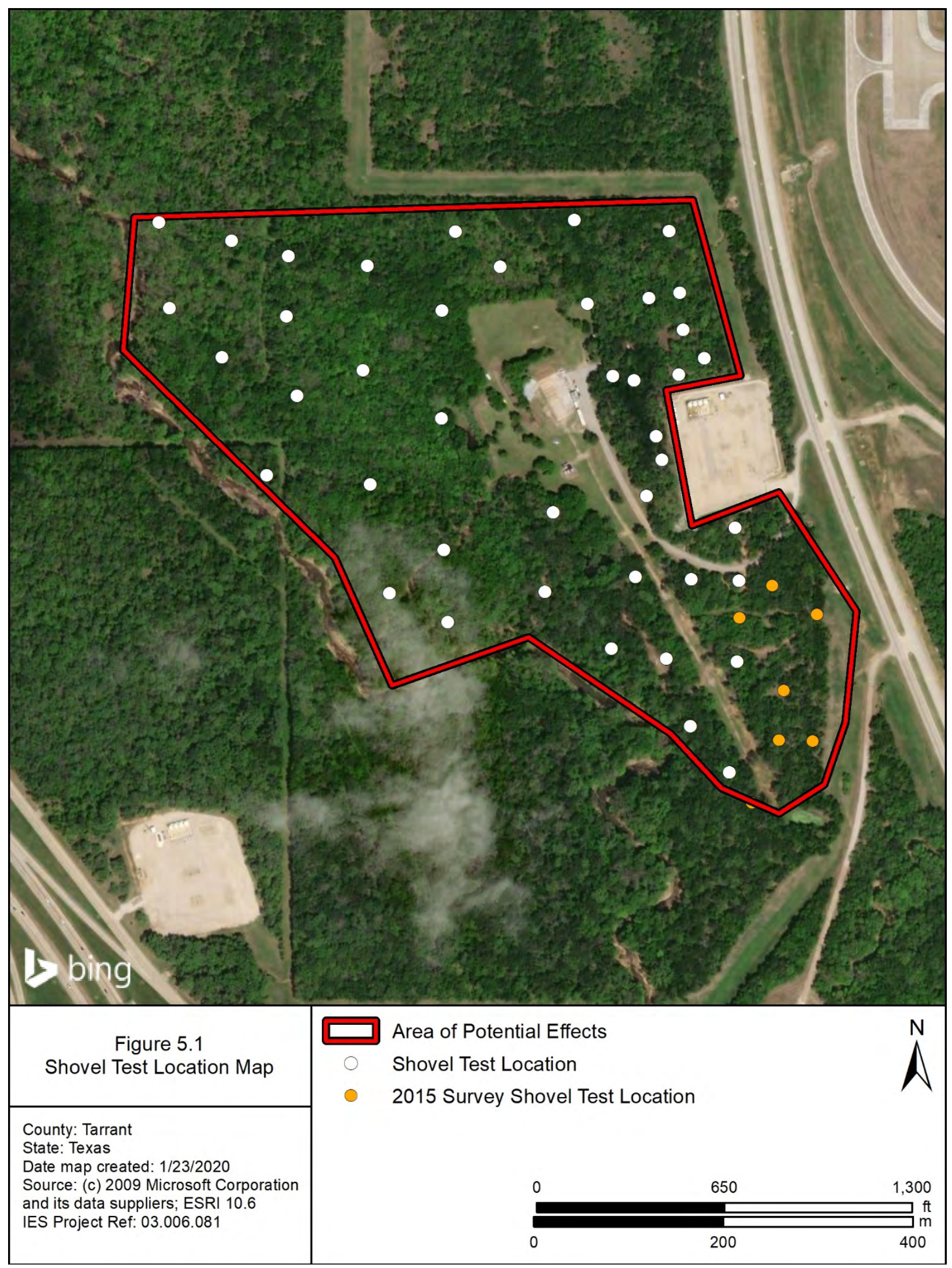

DPS Outdoor Bomb and Gun Range Project 
Soils exposed within shovel tests across the APE revealed a profile that transitioned from very dark grayish brown (10YR 3/2 or 3/3) to dark yellowish brown (10YR 4/3 or 4/4) to depths of approximately 10 to 20 $\mathrm{cmbs}$ in the eastern portion of the APE and 50 to $60 \mathrm{cmbs}$ in the western portion near Big Bear Creek (Table 5.1). Soil textures were generally characterized as clay loam or sandy clay loam. Below the upper stratum, soils ranged from a strong brown to yellowish brown (7.5YR 4/6 or 10YR 5/6) sandy clay to a dark brown or dark yellowish brown (10YR 3/3 or 4/4) clay loam subsoil horizon. Portions of the APE contained a deeper stratum consisting of a yellowish brown (10YR 5/8) clay loam. The maximum depth of the shovel tests was approximately $80 \mathrm{cmbs}$ with most terminating between 30 to $60 \mathrm{cmbs}$ due to encountering the culturally sterile subsoil horizon or bedrock. In addition to shovel testing, subsurface exposures including animal burrows, disturbed patches, and the exposed cut banks of Big Bear Creek and its associated tributary were examined.

Table 5-1: Shovel Test Results

\begin{tabular}{|c|c|c|c|c|}
\hline $\begin{array}{c}\text { Shovel } \\
\text { Test }\end{array}$ & Stratum 1 & Stratum 2 & Stratum 3 & Reason for Termination \\
\hline AG1 & 0 - 35 cmbs: 10 YR $3 / 3$ clay & 35 - 42 cmbs 10 YR $4 / 4$ clay & - & Sterile Subsoil at $42 \mathrm{cmbs}$ \\
\hline AG2 & $\begin{array}{l}0-12 \text { cmbs: } 7.5 \text { YR } 4 / 4 \text { clay } \\
\text { loam }\end{array}$ & $\begin{array}{l}12 \text { - } 30 \text { cmbs: } 7.5 \text { YR } 5 / 8 \text { clay } \\
\text { loam }\end{array}$ & - & Sterile Subsoil at $30 \mathrm{cmbs}$ \\
\hline AG3 & $\begin{array}{l}0 \text { - } 10 \text { cmbs: } 10 \text { YR } 4 / 4 \\
\text { loam }\end{array}$ & 10 - 20 cmbs: 7.5 YR $4 / 6$ clay & - & Sterile Subsoil at $20 \mathrm{cmbs}$ \\
\hline AG4 & $\begin{array}{l}0-5 \text { cmbs: } 10 \text { YR } 3 / 4 \text { sandy } \\
\text { loam }\end{array}$ & $\begin{array}{l}5 \text { - } 24 \text { cmbs: } 10 \text { YR } 4 / 4 \text { sandy } \\
\text { clay }\end{array}$ & - & Sterile Subsoil at $24 \mathrm{cmbs}$ \\
\hline AG5 & $0-5$ cmbs: 10 YR $3 / 6$ loam & 5 - 27 cmbs: 10 YR $5 / 6$ clay & - & Sterile Subsoil at $27 \mathrm{cmbs}$ \\
\hline AG6 & $\begin{array}{l}0 \text { - } 10 \text { cmbs: } 10 Y R 3 / 4 \\
\text { loam }\end{array}$ & 10 - 25 cmbs: 5YR 4/6 clay & - & Sterile Subsoil at $25 \mathrm{cmbs}$ \\
\hline AG7 & $\begin{array}{l}0 \text { - } 10 \text { cmbs: } 10 \text { YR } 3 / 4 \\
\text { loam }\end{array}$ & $\begin{array}{l}10-35 \text { cmbs: } 10 \text { YR } 4 / 6 \\
\text { sandy clay }\end{array}$ & $\begin{array}{l}35 \text { - } 40 \text { cmbs: } 10 \text { YR } 5 / 8 \\
\text { clay }\end{array}$ & Sterile Subsoil at $40 \mathrm{cmbs}$ \\
\hline AG8 & $\begin{array}{l}0 \text { - } 20 \text { cmbs: } 10 \text { YR } 3 / 4 \\
\text { loam }\end{array}$ & $\begin{array}{l}20 \text { - } 30 \text { cmbs: } 10 \text { YR } 4 / 6 \\
\text { sandy clay }\end{array}$ & - & Sterile Subsoil at $30 \mathrm{cmbs}$ \\
\hline AG9 & $\begin{array}{l}0-50 \text { cmbs: } 10 \text { YR } 3 / 4 \text { clay } \\
\text { loam }\end{array}$ & - & - & Large Roots at $50 \mathrm{cmbs}$ \\
\hline AG10 & $\begin{array}{l}0 \text { - } 10 \text { cmbs: } 10 \text { YR } 3 / 4 \\
\text { loam }\end{array}$ & $\begin{array}{l}10 \text { - } 40 \text { cmbs: } 10 \text { YR } 4 / 6 \\
\text { sandy loam }\end{array}$ & - & Large Roots at $40 \mathrm{cmbs}$ \\
\hline AG11 & $\begin{array}{l}0 \text { - } 40 \text { cmbs: } 10 \text { YR } 4 / 1 \text { clay } \\
\text { loam }\end{array}$ & - & - & Water Table at $40 \mathrm{cmbs}$ \\
\hline AG12 & $\begin{array}{l}0 \text { - } 45 \text { cmbs: } 10 \text { YR } 3 / 2 \text { clay } \\
\text { loam }\end{array}$ & 45 - 50 cmbs: 10 YR $3 / 1$ clay & - & Sterile Subsoil at $50 \mathrm{cmbs}$ \\
\hline AG13 & $\begin{array}{l}0-10 \text { cmbs: } 10 \text { YR } 3 / 2 \\
\text { loam }\end{array}$ & $\begin{array}{l}10 \text { - } 60 \text { cmbs: } 10 \text { YR } 4 / 4 \\
\text { sandy clay loam }\end{array}$ & $\begin{array}{l}60 \text { - } 65 \text { cmbs: } 10 \text { YR } 5 / 8 \\
\text { sandy clay loam }\end{array}$ & Sterile Subsoil at $65 \mathrm{cmbs}$ \\
\hline AG14 & 0 - 5 cmbs: 10 YR $3 / 2$ loam & $\begin{array}{l}5-80 \mathrm{cmbs}: 10 \mathrm{YR} 4 / 4 \text { sandy } \\
\text { clay loam }\end{array}$ & - & Depth at $80 \mathrm{cmbs}$ \\
\hline AG15 & $0-15$ cmbs 10 YR $3 / 2$ loam & $\begin{array}{l}15 \text { - } 40 \text { cmbs: } 10 \text { YR } 5 / 8 \\
\text { sandy clay loam }\end{array}$ & $\begin{array}{l}40-50 \text { cmbs: } 7.5 \text { YR } 5 / 8 \\
\text { sandy clay }\end{array}$ & Sterile Subsoil at $50 \mathrm{cmbs}$ \\
\hline AG16 & $\begin{array}{l}0 \text { - } 10 \text { cmbs: } 10 \text { YR } 4 / 4 \\
\text { sandy clay loam }\end{array}$ & $\begin{array}{l}10-35 \text { cmbs: } 7.5 \text { YR } 3 / 2 \\
\text { sandy clay loam }\end{array}$ & - & Regolith/Bedrock at $35 \mathrm{cmbs}$ \\
\hline AG17 & $\begin{array}{l}0 \text { - } 20 \text { cmbs: } 10 Y R \quad 4 / 2 \\
\text { sandy loam }\end{array}$ & $\begin{array}{l}20 \text { - } 30 \text { cmbs: } 5 \text { YR } 4 / 4 \text { sandy } \\
\text { clay loam }\end{array}$ & - & Regolith/Bedrock at $30 \mathrm{cmbs}$ \\
\hline JRM1 & $\begin{array}{l}0 \text { - } 20 \text { cmbs: } 10 \mathrm{YR} 4 / 4 \\
\text { sandy clay }\end{array}$ & $\begin{array}{l}20 \text { - } 35 \text { cmbs: } 7.5 \text { YR } 4 / 6 \\
\text { sandy clay }\end{array}$ & - & Sterile Subsoil at $35 \mathrm{cmbs}$ \\
\hline JRM2 & $\begin{array}{l}0 \text { - } 45 \text { cmbs: } 7.5 \text { YR } 4 / 4 \text { clay } \\
\text { loam }\end{array}$ & $\begin{array}{l}45 \text { - } 55 \text { cmbs: } 10 \text { YR } 3 / 2 \\
\text { sandy loamy clay }\end{array}$ & - & Sterile Subsoil at $55 \mathrm{cmbs}$ \\
\hline JRM3 & $\begin{array}{l}0 \text { - } 50 \text { cmbs: } 10 Y R \quad 4 / 4 \\
\text { loamy clay }\end{array}$ & $\begin{array}{l}50 \text { - } 60 \text { cmbs: } 10 \text { YR } 3 / 2 \\
\text { sandy clay }\end{array}$ & - & Sterile Subsoil at $60 \mathrm{cmbs}$ \\
\hline JRM4 & $\begin{array}{l}0 \text { - } 55 \text { cmbs: } 10 Y R \quad 4 / 4 \\
\text { loamy clay }\end{array}$ & $\begin{array}{l}55 \text { - } 65 \text { cmbs: } 10 \text { YR } 3 / 2 \\
\text { sandy clay }\end{array}$ & - & Sterile Subsoil at $65 \mathrm{cmbs}$ \\
\hline JRM5 & $\begin{array}{l}0 \text { - } 40 \text { cmbs: } 10 Y R \quad 4 / 6 \\
\text { sandy loam }\end{array}$ & $\begin{array}{l}40 \text { - } 50 \text { cmbs: } 10 \text { YR } 6 / 6 \\
\text { sandy loamy clay }\end{array}$ & - & Sterile Subsoil at $50 \mathrm{cmbs}$ \\
\hline JRM6 & $\begin{array}{l}0 \text { - } 45 \text { cmbs: } 10 \text { YR } 3 / 3 \\
\text { sandy clay loam }\end{array}$ & $\begin{array}{l}45-55 \text { cmbs: } 10 \text { YR } 5 / 6 \\
\text { sandy clay }\end{array}$ & - & Sterile Subsoil at $55 \mathrm{cmbs}$ \\
\hline JRM7 & $\begin{array}{l}0 \text { - } 50 \text { cmbs: } 10 \text { YR } 3 / 3 \\
\text { sandy clay loam }\end{array}$ & $\begin{array}{l}50-60 \text { cmbs: } 10 \text { YR } 5 / 6 \\
\text { sandy loamy clay }\end{array}$ & - & Sterile Subsoil at $60 \mathrm{cmbs}$ \\
\hline JRM8 & $\begin{array}{l}0 \text { - } 55 \text { cmbs: } 10 \mathrm{YR} 3 / 3 \\
\text { sandy loamy clay }\end{array}$ & $\begin{array}{l}55 \text { - } 65 \text { cmbs: } 10 \text { YR } 5 / 6 \\
\text { sandy clay }\end{array}$ & - & Sterile Subsoil at $65 \mathrm{cmbs}$ \\
\hline
\end{tabular}




\begin{tabular}{|c|c|c|c|c|}
\hline $\begin{array}{c}\text { Shovel } \\
\text { Test }\end{array}$ & Stratum 1 & Stratum 2 & Stratum 3 & Reason for Termination \\
\hline JRM9 & $\begin{array}{l}0 \text { - } 25 \text { cmbs: } 7.5 \text { YR } 3 / 4 \\
\text { sandy loam }\end{array}$ & $\begin{array}{l}25 \text { - } 35 \text { cmbs: } 5 \text { YR 5/8 sandy } \\
\text { clay }\end{array}$ & - & Sterile Subsoil at $35 \mathrm{cmbs}$ \\
\hline JRM10 & $\begin{array}{l}0 \text { - } 25 \text { cmbs: } 7.5 \text { YR } 4 / 6 \\
\text { loamy sand }\end{array}$ & $\begin{array}{l}25 \text { - } 40 \text { cmbs: } 7.5 \text { YR } 7 / 8 \\
\text { sand }\end{array}$ & - & Regolith/Bedrock at $40 \mathrm{cmbs}$ \\
\hline JRM11 & $\begin{array}{l}0 \text { - } 35 \text { cmbs: } 7.5 \text { YR } 4 / 6 \\
\text { loamy sand }\end{array}$ & - & - & Regolith/Bedrock at $35 \mathrm{cmbs}$ \\
\hline JRM12 & $\begin{array}{l}0 \text { - } 10 \text { cmbs: } 10 \text { YR } 3 / 4 \\
\text { sandy loamy clay }\end{array}$ & 10 - 25 cmbs: 7.5 YR $6 / 8$ clay & - & Regolith/Bedrock at $25 \mathrm{cmbs}$ \\
\hline JRM13 & $\begin{array}{l}0 \text { - } 10 \text { cmbs: } 10 \text { YR } 3 / 3 \\
\text { sandy loam }\end{array}$ & $10-30 \mathrm{cmbs} 7.5$ YR $5 / 8$ clay & - & Sterile Subsoil at $30 \mathrm{cmbs}$ \\
\hline $\mathrm{TC} 1$ & $\begin{array}{l}0 \text { - } 10 \text { cmbs: } 10 \text { YR } 3 / 2 \\
\text { sandy loam }\end{array}$ & $\begin{array}{l}10 \text { - } 55 \text { cmbs: } 10 \text { YR } 4 / 4 \text { clay } \\
\text { loam }\end{array}$ & $\begin{array}{l}55 \text { - } 80 \text { cmbs: } 10 \text { YR } 5 / 8 \\
\text { clay loam }\end{array}$ & Depth at $80 \mathrm{cmbs}$ \\
\hline $\mathrm{TC} 2$ & $\begin{array}{l}0-15 \text { cmbs: } 10 Y R 3 / 2 \\
\text { loam }\end{array}$ & $\begin{array}{l}15 \text { - } 70 \text { cmbs: } 10 Y R \quad 4 / 3 \text { clay } \\
\text { loam }\end{array}$ & $\begin{array}{l}70-80 \text { cmbs: } 10 \text { YR } 5 / 8 \\
\text { clay loam }\end{array}$ & Depth at $80 \mathrm{cmbs}$ \\
\hline TC3 & $\begin{array}{l}0 \text { - } 20 \text { cmbs: } 10 \text { YR } 3 / 3 \text { clay } \\
\text { loam }\end{array}$ & $\begin{array}{l}20 \text { - } 70 \text { cmbs: } 10 \text { YR } 4 / 3 \\
\text { sandy loam }\end{array}$ & $\begin{array}{l}70-75 \text { cmbs: } 10 \text { YR } 5 / 6 \\
\text { clay loam }\end{array}$ & Sterile Subsoil at $75 \mathrm{cmbs}$ \\
\hline TC4 & $\begin{array}{l}0 \text { - } 60 \text { cmbs: } 10 \text { YR } 3 / 2 \\
\text { sandy loam }\end{array}$ & $\begin{array}{l}60 \text { - } 70 \text { cmbs: } 10 \text { YR } 4 / 4 \\
\text { sandy loam }\end{array}$ & - & Sterile Subsoil at $70 \mathrm{cmbs}$ \\
\hline TC5 & $\begin{array}{l}0-60 \text { cmbs: } 10 \text { YR } 3 / 2 \text { clay } \\
\text { loam }\end{array}$ & $\begin{array}{l}60 \text { - } 70 \text { cmbs: } 10 \text { YR } 3 / 3 \text { clay } \\
\text { loam }\end{array}$ & - & Sterile Subsoil at $70 \mathrm{cmbs}$ \\
\hline TC6 & $\begin{array}{l}0-25 \text { cmbs: } 10 Y R \quad 4 / 4 \\
\text { loam }\end{array}$ & $\begin{array}{l}25 \text { - } 65 \text { cmbs: } 10 \text { YR } 3 / 3 \text { clay } \\
\text { loam }\end{array}$ & $\begin{array}{l}65-75 \text { cmbs: } 10 \text { YR } 5 / 6 \\
\text { clay loam }\end{array}$ & Sterile Subsoil at $75 \mathrm{cmbs}$ \\
\hline $\mathrm{TC7}$ & $\begin{array}{l}0-65 \text { cmbs: } 10 Y R 3 / 2 \\
\text { loam }\end{array}$ & $\begin{array}{l}65-70 \text { cmbs: } 10 Y R 4 / 4 \text { clay } \\
\text { loam }\end{array}$ & - & Sterile Subsoil at $70 \mathrm{cmbs}$ \\
\hline TC8 & $\begin{array}{l}0 \text { - } 50 \text { cmbs: } 10 \text { YR } 4 / 2 \\
\text { loam }\end{array}$ & $\begin{array}{l}50 \text { - } 60 \text { cmbs: } 10 \text { YR } 4 / 4 \text { clay } \\
\text { loam }\end{array}$ & - & Sterile Subsoil at $60 \mathrm{cmbs}$ \\
\hline TC9 & $\begin{array}{l}0-50 \text { cmbs: 10YR 2/1 clay } \\
\text { loam }\end{array}$ & $\begin{array}{l}50 \text { - } 60 \text { cmbs: } 10 \text { YR } 4 / 4 \text { clay } \\
\text { loam }\end{array}$ & - & Sterile Subsoil at $60 \mathrm{cmbs}$ \\
\hline $\mathrm{TC} 10$ & $\begin{array}{l}0 \text { - } 45 \text { cmbs: } 10 \text { YR } 3 / 3 \text { clay } \\
\text { loam }\end{array}$ & $\begin{array}{l}45 \text { - } 60 \text { cmbs: } 10 Y R \quad 4 / 3 \\
\text { sandy loam }\end{array}$ & - & Sterile Subsoil at $60 \mathrm{cmbs}$ \\
\hline TC11 & $\begin{array}{l}0 \text { - } 60 \text { cmbs: } 10 \text { YR } 3 / 2 \\
\text { loam }\end{array}$ & $\begin{array}{l}60 \text { - } 70 \text { cmbs: } 10 \text { YR } 4 / 3 \\
\text { sandy loam }\end{array}$ & - & Sterile Subsoil at $70 \mathrm{cmbs}$ \\
\hline $\mathrm{TC} 12$ & $\begin{array}{l}0 \text { - } 60 \text { cmbs: } 10 Y R \text { R/3 } \\
\text { sandy loam }\end{array}$ & $\begin{array}{l}60-75 \text { cmbs: } 10 \text { YR } 4 / 2 \\
\text { sandy loam }\end{array}$ & - & Sterile Subsoil at $75 \mathrm{cmbs}$ \\
\hline
\end{tabular}

\section{$\underline{5.2}$ Encountered Cultural Resources}

\subsection{1 $41 T R 18$}

Although a portion of site 41TR18 was within the direct APE boundaries, this area was not investigated for the proposed DPS Outdoor Bomb and Gun Range project as it had been previously surveyed by IES in 2015. During the 2015 revisit of 41 TR18 (Stone et al. 2018), the features and artifacts originally recorded for the site were not encountered within the current boundaries depicted within the TASA database. Through prior coordination with the THC, the agency determined that 41TR18 was not eligible for NRHP listing (Appendix B).

\subsection{2 $41 T R 87$}

\subsubsection{Previous Investigations}

Site 41TR87 was originally recorded in 1982 by Daniel Prikryl during the Bear Creek cultural resources survey of the creek's drainage system (1990). At the time of its initial documentation, the site was described as containing a prehistoric component, which was damaged by historic occupation (Prikryl 1990). No shovel tests or other subsurface investigations were performed at that time due to dense vegetation.

The site was revisited during the 2008 ARC archeological survey for Chesapeake Energy. During the survey, ARC archeologists encountered a low-density scatter of prehistoric lithic debitage and historic-age house foundations at the top of a ridge (Shelton et al. 2008). Non-diagnostic quartzite flakes and chips were encountered on the surface and up to $100 \mathrm{cmbs}$ in positive shovel tests. Four concrete house foundations (Features A, B, C, and D) were recorded during the ARC survey. According to background research performed by ARC, the houses were constructed between 1953 and 1956. A scatter of modern 
trash was observed throughout the site. In 2008, site 41TR87 was determined by the THC to be ineligible for listing on the NRHP.

\subsubsection{Current Investigation}

During the IES survey, archeologists revisited 41TR87 to reassess the current condition of the site and to assess the potential for further testing and eligibility. The site was encountered on a ridge east of the DPS gun range facility and west of West Airfield Road (Figure 5.2). The site was documented within an area extending approximately $656 \mathrm{ft}(200 \mathrm{~m})$ north-to-south by $426 \mathrm{ft}(130 \mathrm{~m})$ east-to-west, encompassing approximately $5.36 \mathrm{ac}(2.17 \mathrm{ha})$, including a portion of the original site outside of the APE. As a result of field observations, the site boundaries were extended to the western slope of the ridge between Range Road and a tributary of Big Bear Creek (see Figure 5.2). The site was delineated based on the distribution of archeological features, surface artifacts, negative shovel tests, APE limits, and observed disturbances. Because of the nature of the site and a previous determination of ineligibility for NRHP listing, site 41TR87 was delineated by IES according to the THC's standard of a minimum six shovel tests for an archeological site delineation to reassess site limits and condition.

Eleven shovel tests were excavated within and surrounding the 5.36 ac site. Shovel tests contained a soil profile characterized by an upper stratum of dark yellowish brown (10YR 3/4) loam or strong brown (7.5YR 4/6) sandy loam. Below the upper stratum, soils ranged from a strong brown to yellowish brown (7.5YR $4 / 6$ or 10 YR $5 / 6$ ) sandy clay to a dark brown or dark yellowish brown (10YR 3/3 or 4/4) clay loam subsoil horizon. Shovel tests were generally terminated between 20 and $30 \mathrm{cmbs}$ due to culturally sterile subsoil or bedrock. No subsurface artifacts were encountered during the site revisit.

Ground surface visibility was limited throughout the site during the survey. Little of the ground surface was visible on the ridge due to dense leaf litter and moderate vegetation growth. Investigators observed sparse to moderate surface artifact scatters containing a variety of domestic artifacts, as well as the remnants of concrete foundation footers. The prehistoric component mentioned by Prikryl and documented during the 2008 ARC survey was not encountered during the IES site revisit. In addition, IES archeologists observed previously identified features $\mathrm{A}, \mathrm{B}$, and $\mathrm{C}$ had been destroyed by the installation of a pad site directly east of the APE (see Appendix A, Photographs 43 and 44).

\subsubsection{Features}

Feature D was a series of raised concrete foundations measuring approximately 50 by $32 \mathrm{ft}$ ( 15 by $10 \mathrm{~m}$; Appendix A, Photographs 48 through 55). This feature was located approximately $105 \mathrm{ft}(32 \mathrm{~m})$ north of the former location of Feature $\mathrm{C}$ and pertained to a residential house. The concrete foundations consisted of wall footings with anchor bolts extruding from the surface, cylindrical floor footings, and two sets of stairs. A small room with a small window at ground level was observed north of the western stair set (Appendix A, Photograph 56). IES investigators also identified a driveway at the north end of the foundations and a concrete-slab at the edge of the ridge top to the west (Appendix A, Photographs 57 and 58). The only artifacts observed were unmarked bricks scattered around the northern side of the former house (Appendix A, Photograph 59). A collapsed cistern and a concrete pad with a center pipe and associated modern trash mapped by ARC in 2008 were not encountered during the IES intensive survey; however, ground visibility was limited surrounding the feature due to a dense layer of leaf litter and young secondary tree growth. According to historical aerial photographs, the house associated with Feature D was demolished between 1971 and 1973 (Figures 5.3 and 5.4).

Feature E was a historic-age artifact scatter measuring approximately 34 by $83 \mathrm{ft}$ ( 10 by $25 \mathrm{~m}$; Appendix A, Photographs 60 and 61). The scatter was located on an eroded bedrock terrace approximately $86 \mathrm{ft}$ (26 $\mathrm{m})$ southwest of the former location of Feature B. The feature was composed of mostly metal artifacts including food cans, oil drum barrels, a folding chair, a toy wagon, a bowl, a toaster, and coiled wire 
This page has been removed intentionally to protect sensitive

\author{
cultural materials
}

Figure 5.2 
This page has been removed intentionally to protect sensitive

\author{
cultural materials
}

Figure 5.3 
This page has been removed intentionally to protect sensitive

\author{
cultural materials
}

Figure 5.4 
(Appendix A, Photographs 62 through 65). IES investigators also observed a fragmented stoneware crock, refined earthenware, and marked clear and brown glass bottles (Appendix A, Photographs 66 through 75). Based on maker's marks and design, glass bottles observed in Feature E generally dated to the mid-20 ${ }^{\text {th }}$ century (Lindsey 2020). A group of domesticated irises were observed growing at the eastern end of the scatter (Appendix A, Photograph 76). Based on the placement and setting, it was determined that this scatter was once associated with the house identified as Feature B.

Feature $\mathbf{F}$ was a section of fencing measuring approximately $15 \mathrm{ft}(5 \mathrm{~m})$ in a north-to-south orientation (Appendix A, Photograph 77). This feature most likely pertained to an animal pen originally associated with Feature C. The fence was constructed of wooden posts, wire mesh, and a board along the base of the wire mesh.

Feature $\mathbf{G}$ was a historic-age artifact scatter measuring approximately 18 by $36 \mathrm{ft}(5.4$ by $10.9 \mathrm{~m})$ near a maintenance and storage area for the current facility (Appendix A, Photographs $\mathbf{7 8}$ through 80). The feature was located approximately $159 \mathrm{ft}(48 \mathrm{~m})$ west of Feature D. The low-density scatter was mostly comprised of manufactured metal containers for domestic goods and clear glass bottles. One bottle featured a maker's mark for Brockway Glass Co. (1933-1980) and characteristics common to bottles dating from the mid to late 20 th century (Lindsey 2020; Appendix A, Photograph 81 and 82). A small group of domesticated irises were growing between the artifact scatter and maintenance road to the north (Appendix A, Photograph 83). Modern trash was observed north of the scatter near the maintenance area.

\subsubsection{Site Summary}

Site 41TR87 represents a historic-period residence occupied during the mid- $20^{\text {th }}$ century. The site is located in an area approximately $656 \mathrm{ft}(200 \mathrm{~m})$ north-to-south by $426 \mathrm{ft}(130 \mathrm{~m})$ east-to-west, encompassing approximately $5.36 \mathrm{ac}(2.17 \mathrm{ha})$ within and outside of the APE. Eleven shovel tests were excavated within or in proximity to the site during intensive survey and site delineation, none of which yielded cultural materials. During the IES survey, a previously recorded house foundation feature was revisited. In addition, three newly recorded features were identified on the western ridge slope. 
This page intentionally left blank

DPS Outdoor Bomb and Gun Range Project Cultural Resources Survey Report
IES Project No. 03.006.081

Page 30 


\section{CHAPTER 6: SUMMARY AND RECOMMENDATIONS}

\subsection{Archeological Resources}

During the intensive pedestrian survey, 42 shovel tests were excavated within the 71.8 -ac APE. Through the survey, one previously documented archeological site was revisited. Summaries of two archeological resources located within the APE and NRHP/SAL eligibility recommendations are provided within this chapter and within Table 6.1. IES considers 100 percent of the direct APE to be fully assessed for archeological resources at this time and recommends that no further work is warranted.

Table 6-1: Summary of NRHP/SAL Eligibility Recommendations

\begin{tabular}{|c|c|}
\hline Resource ID & NRHP/SAL Eligibility Recommendations \\
\hline \hline $41 \mathrm{TR} 18$ & Not Eligible \\
\hline $41 \mathrm{TR} 87$ & Not Eligible \\
\hline
\end{tabular}

41TR18 was not encountered within the APE and the NRHP-eligibility of the site was not formally assessed or evaluated during this effort. In a 2015 site revisit, IES did not encounter any traces of the prehistoric or historic-age components originally associated with the site. The site is therefore recommended to remain not eligible for inclusion in the NRHP.

41TR87 was a previously recorded archeological site representing a prehistoric lithic scatter and historicage residential area constructed between 1953 and 1956. The site comprised a $656 \mathrm{ft}(200 \mathrm{~m})$ north-tosouth by $426 \mathrm{ft}(130 \mathrm{~m})$ east-to-west area, encompassing approximately $5.36 \mathrm{ac}(2.17 \mathrm{ha})$. At the time of survey, the site contained a concrete house foundation, two artifact scatters, and a fence feature. The previously recorded prehistoric component was not encountered. Three of the four house foundation features recorded by ARC in 2008 have been completely removed from the site outside of the APE. Based on the lack of association with a significant historical event(s) or person(s), the absence of innovative or artistic design elements or architectural features, and the low potential to yield significant archeological data, site 41TR87 is recommended to remain not eligible for listing in the NRHP under Criteria A, B, C, or D nor considered for SAL designation. No further evaluation or mitigation efforts are recommended for this site.

\subsection{Recommendations}

It is the recommendation of IES that the DPS Outdoor Bomb and Gun Range project be permitted to continue without the need for further cultural resources investigations. However, if any cultural resources, other than those detailed within this report, are encountered during construction, other than those discussed within this report, the operators should immediately stop construction activities in those areas. The project cultural resources consultant should then be contacted to initiate further consultation with the THC prior to resuming construction activities in the area of the inadvertent discovery. In addition, if project designs change, and areas outside the APE detailed within this report are to be impacted, additional field investigations may be required. 
This page intentionally left blank

DPS Outdoor Bomb and Gun Range Project Cultural Resources Survey Report
IES Project No. 03.006.081

Page 32 


\section{CHAPTER 7: REFERENCES CITED}

Council of Texas Archeologists (CTA)

2002 Revised Archeological Survey Standards for Texas. CTA Newsletter 26(1).

Diggs, G.M. Jr, B.L. Lipscomb, R. J. O’Kennon

1999 Shinners and Mahler's Illustrated Flora of North Central Texas. SIDA, Botanical, Miscellany, No. 16. Botanical Research Institute of Texas. Ft. Worth, Texas.

Estaville, L., and R. Earl

2008 Texas Water Atlas. Texas A\&M University Press, College Station.

Ferring, C. R.

1994 Late Quaternary Geology of the Upper Trinity River Basin, Texas. Doctoral Dissertation. The University of Texas at Dallas.

Griffith, G., S. Bryce, J. Omernik, and A. Rogers

2007 Ecoregions of Texas. Texas Commission on Environmental Quality, Austin.

Hill, R. T.

1901 The Topography and Geology of the Cross Timbers and Surrounding Regions in North Texas. American Journal of Science 33(196): 291-303.

Lindsey, B.

2020 Historic Glass Bottle Identification \& Information website hosted by the Society for Historical Archaeology. https://sha.org/bottle/ (accessed February 2020).

McGowen, J. H., C. V. Proctor, W. T. Haenggi, D. F. Reaser, and V. E. Barnes

1987 Geological Atlas of Texas, Dallas Sheet. The University of Texas at Austin.

Prikryl, D. J.

1990 Lower Elm Fork Prehistory: A Redefinition of Cultural Concepts and Chronologies along the Trinity River, North-Central Texas. Texas Historical Commission, Office of the State Archeologist Report 37, Austin.

Ressel, D.

1981 Soil Survey of Tarrant County, Texas. United States Department of Agriculture, Soil Conservation Service, in cooperation with Texas Agricultural Experiment Station.

Shelton, R., C. S. Davis, and S. A. Skinner

2008 An Archaeological Survey for Chesapeake Energy Corporation at DFW International Airport Dallas and Tarrant Counties, Texas. AR Consultants, Inc., Dallas.

Stone, K., J. Hamilton, A. Gibson, and T. Chapman

2018 A 2,705-Acre Cultural Resources Survey for the Dallas/Fort Worth International Airport, Dallas and Tarrant Counties, Texas. Integrated Environmental Solutions, McKinney.

Texas Archeological Sites Atlas (TASA)

2019 Texas Archeological Sites Atlas. s.v. "Tarrant County" http://nueces.thc.state.tx.us/ (accessed October 2019).

Texas Historic Sites Atlas (THSA)

2019 Texas Archeological Sites Atlas. s.v. "Tarrant County" http://nueces.thc.state.tx.us/ (accessed October 2019). 
Texas Parks and Wildlife Department (TPWD)

2019 Cross Timbers and Prairies Ecological Region.

http://www.tpwd.state.tx.us/landwater/land/habitats/cross_timbers/ecoregions/cross_timbers.pht m. Online electronic document (accessed October 2019).

U.S. Department of Agriculture (USDA)

2019 Web Soil Survey - Natural Resource Conservation Service Website:

http://websoilsurvey.nrcs.usda.gov/app/WebSoilSurvey (accessed October 2019).

U.S. Geological Survey (USGS)

2019 U.S. Department of the Interior Mineral Resources On-Line Spatial Data Website. http://mrdata.usgs.gov/sgmc/tx.html (accessed September 2019). 
This page has been removed intentionally to protect sensitive

\author{
cultural materials
}

Appendix A

Photograph Location Map 

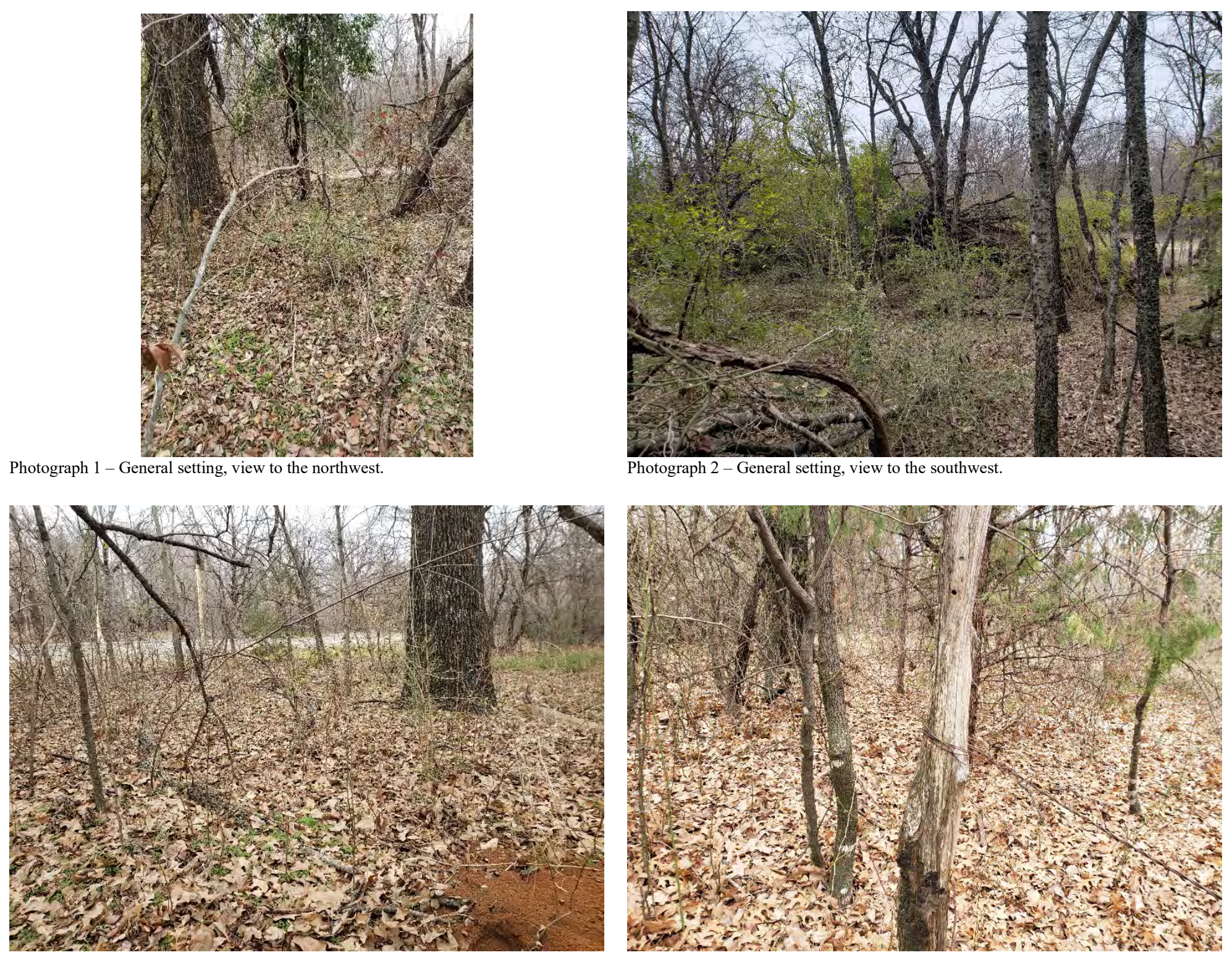

Photograph 3 - General setting, view to the north.
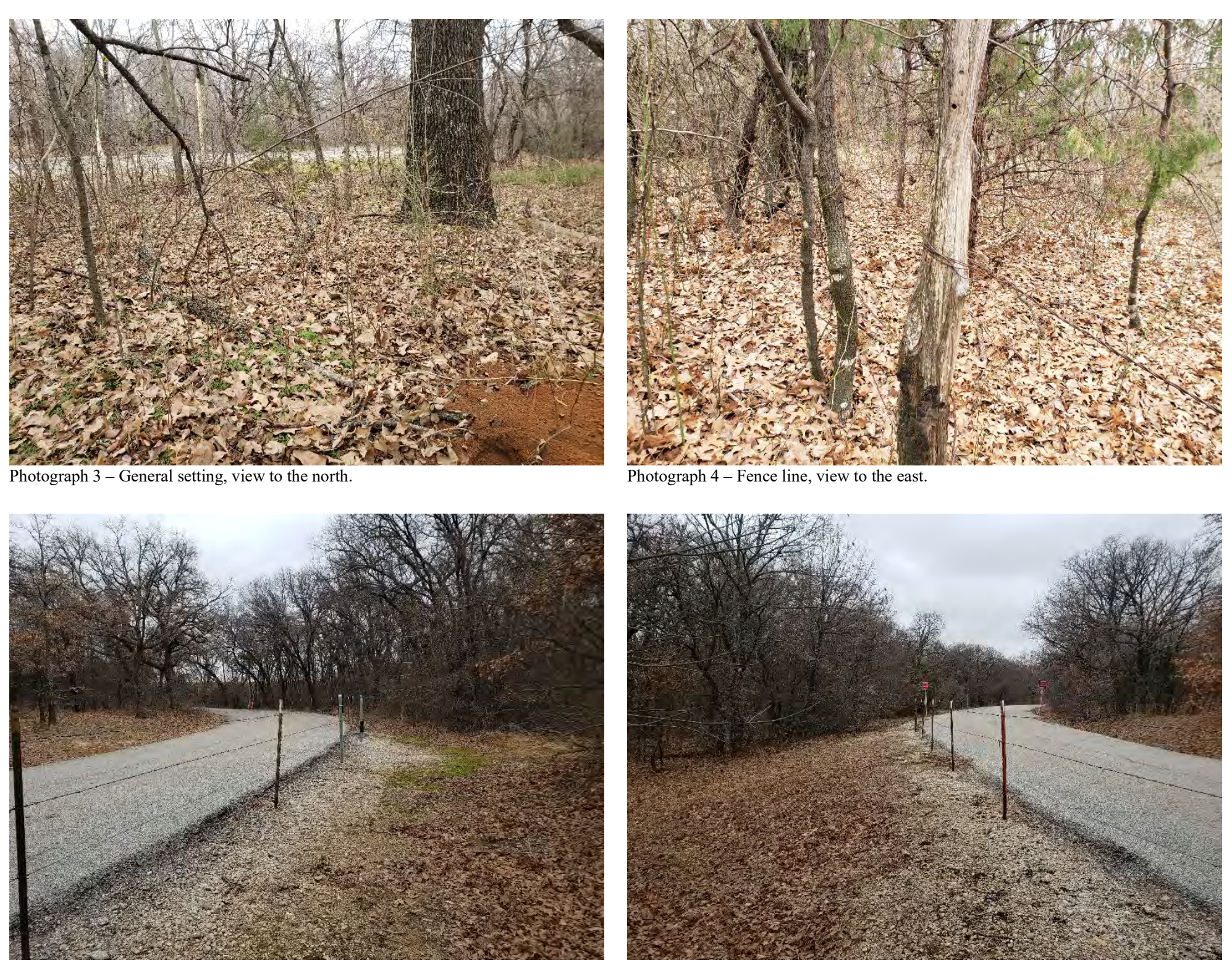

Photograph 5 - Range Road, view to the east.

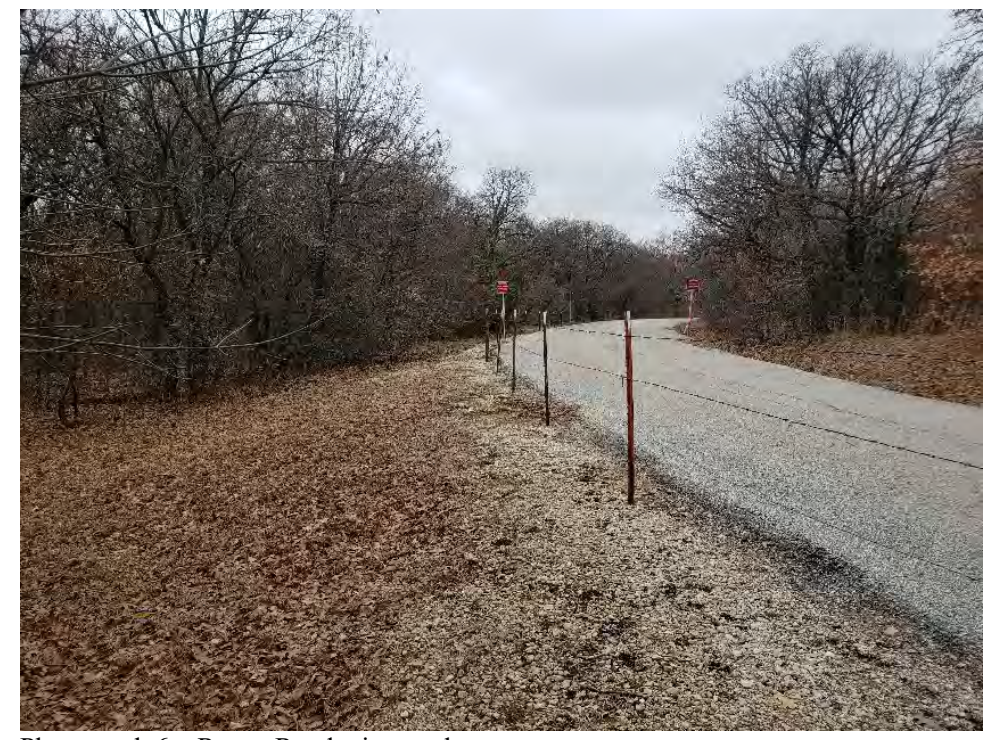

Photograph 6 - Range Road, view to the west. 


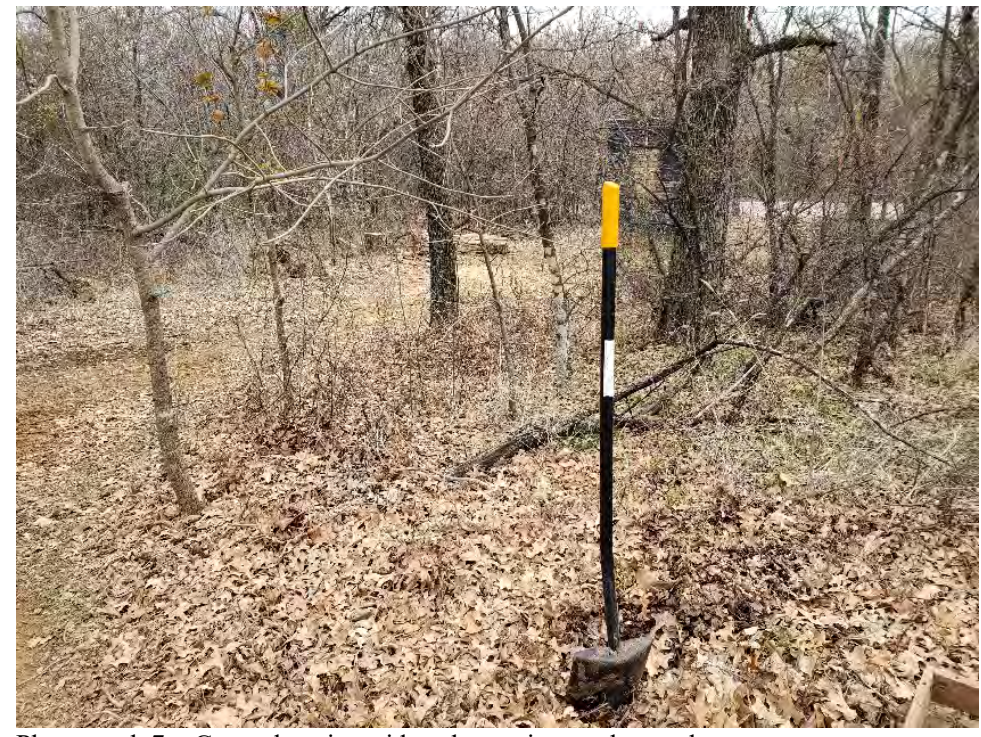
Photograph 7 - General setting, ridge slope, view to the south.

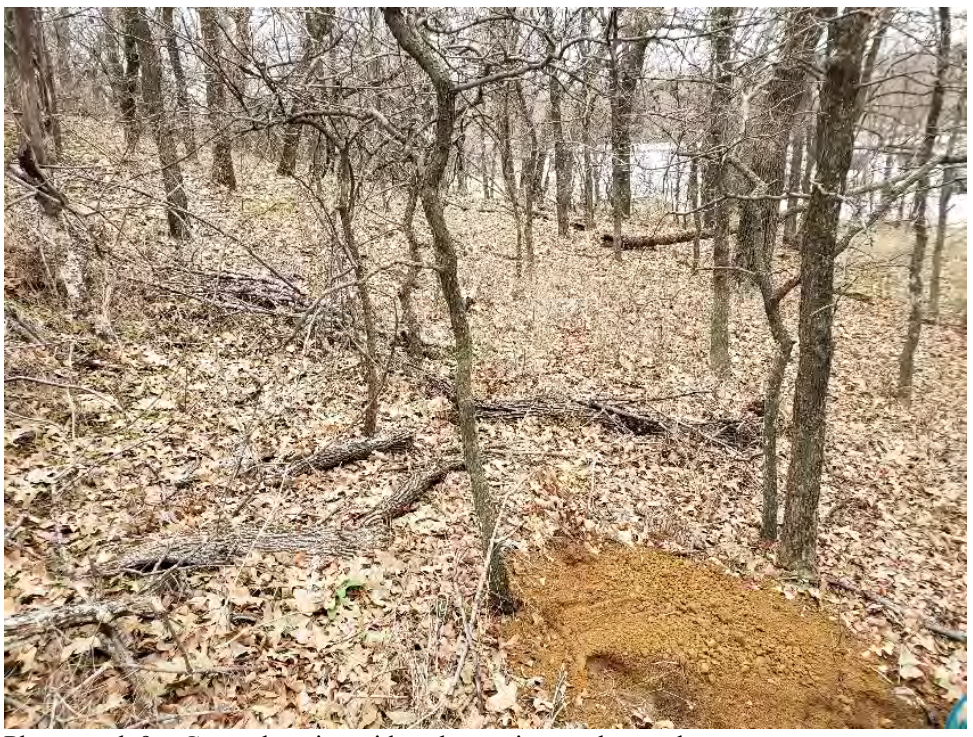

Photograph 9 - General setting, ridge slope, view to the southwest

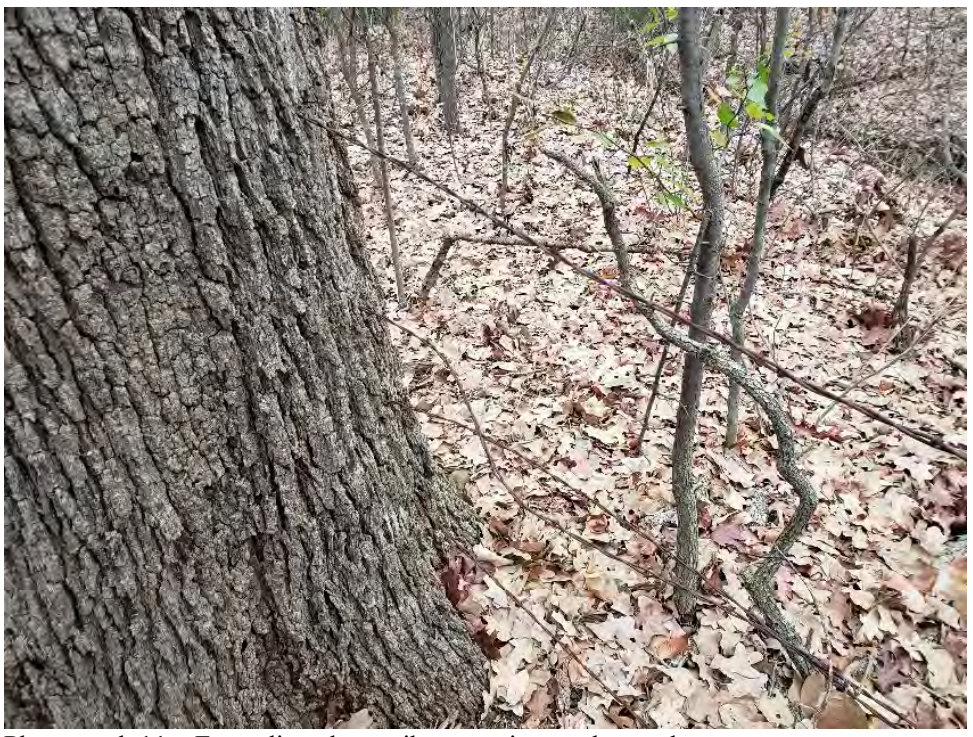

Photograph 11 - Fence line along tributary, view to the northwest.

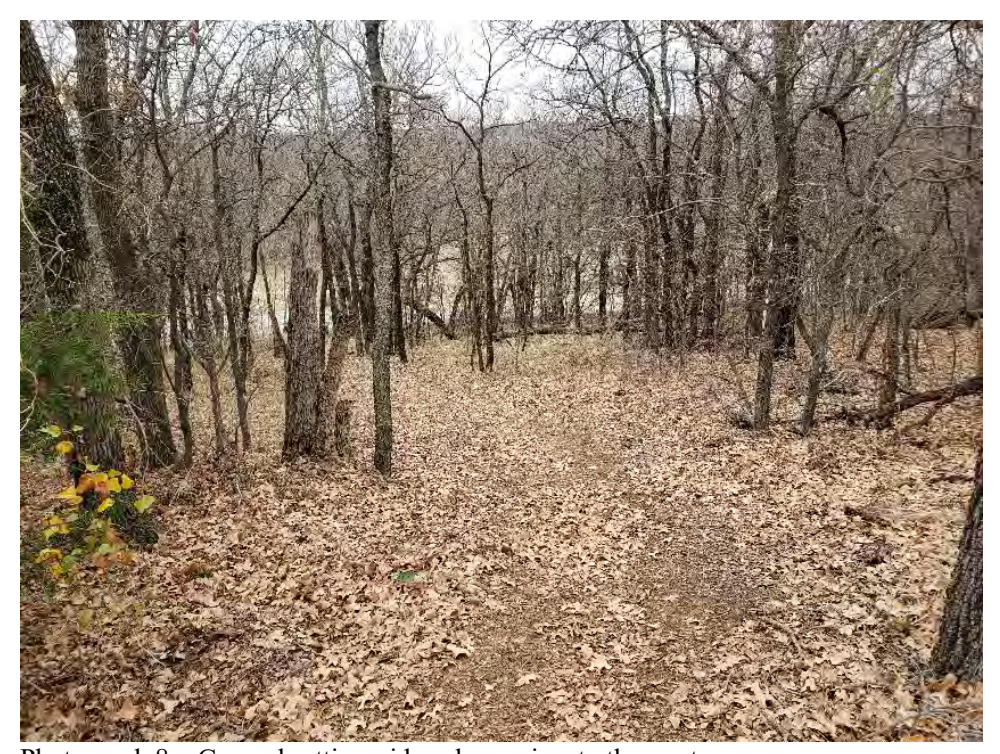

Photograph 8 - General setting, ridge slope, view to the west.

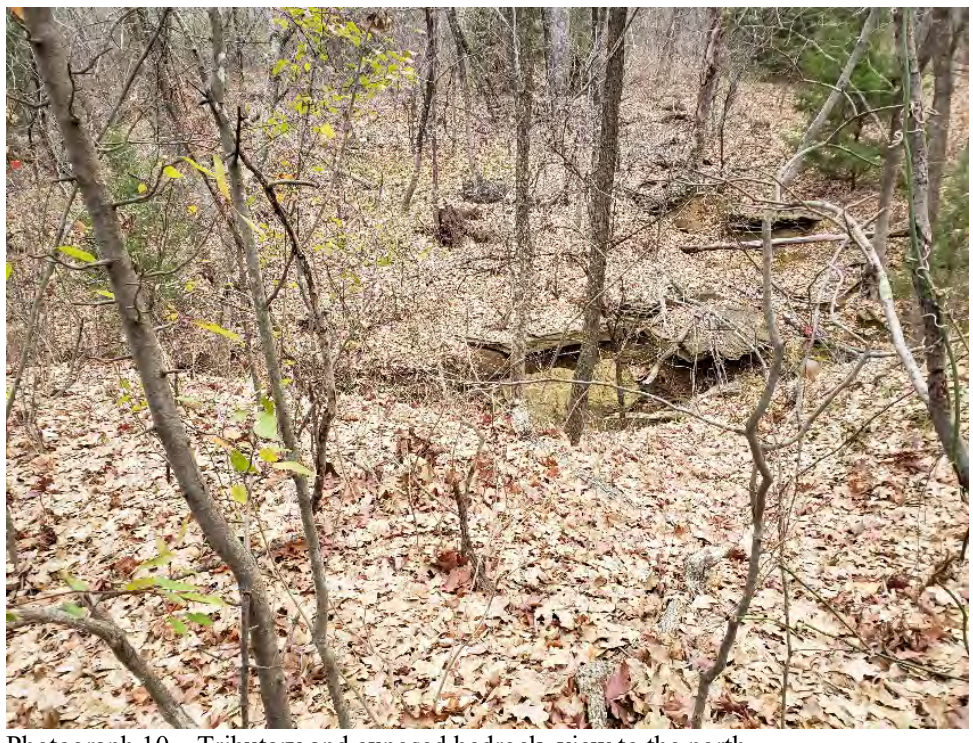

Photograph 10 - Tributary and exposed bedrock, view to the north.

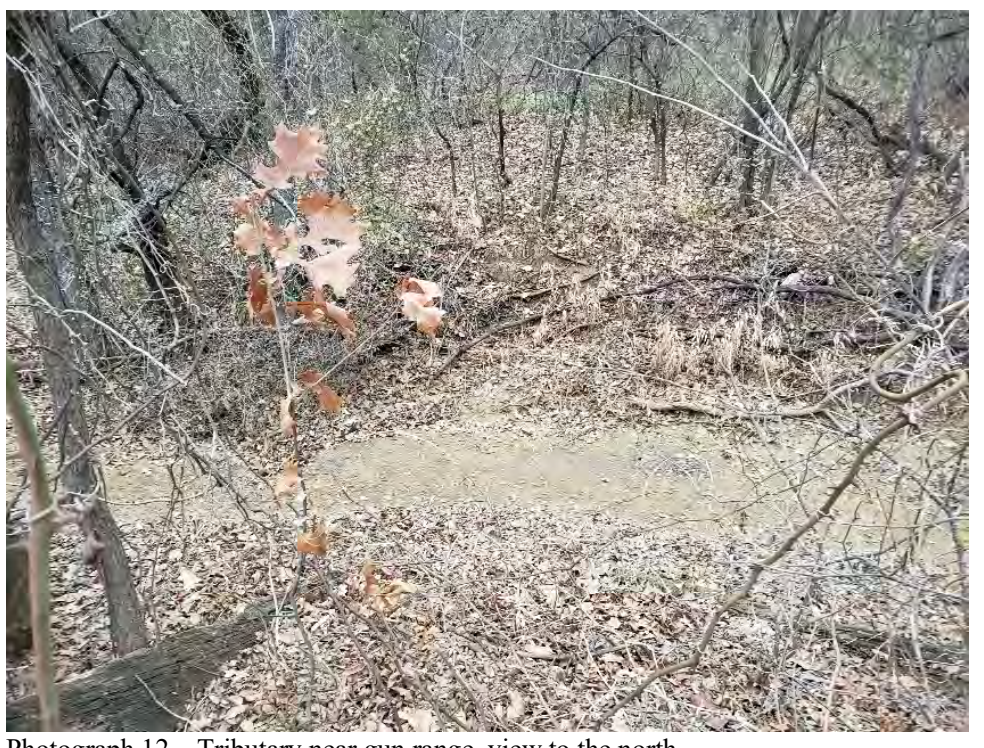

Photograph 12 - Tributary near gun range, view to the north. 


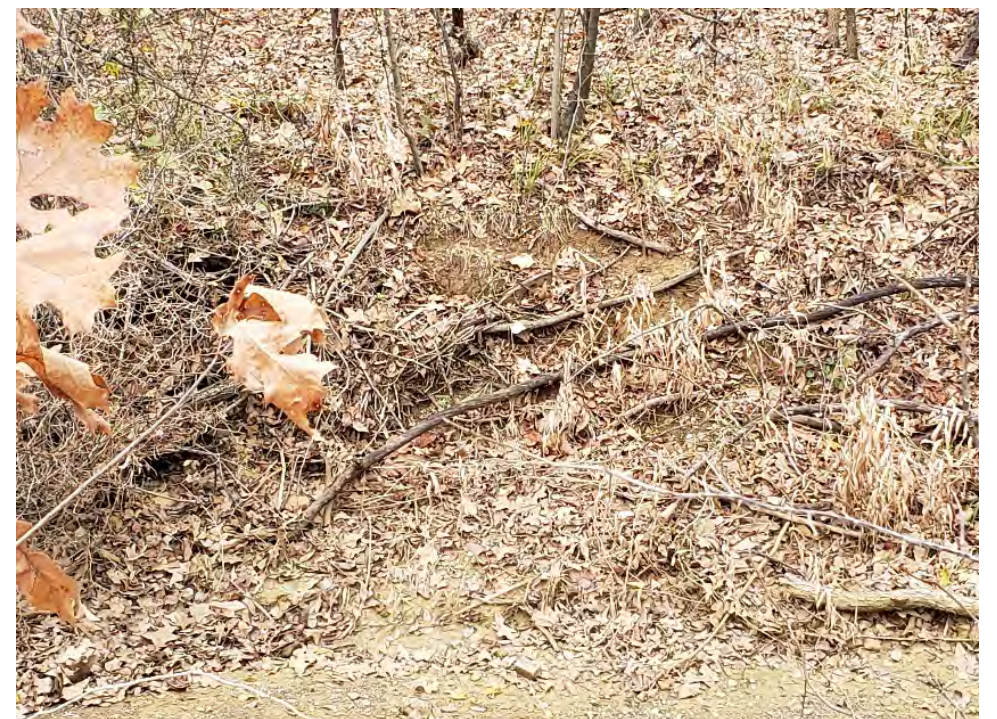

Photograph 13 - Cut bank, view to the north.

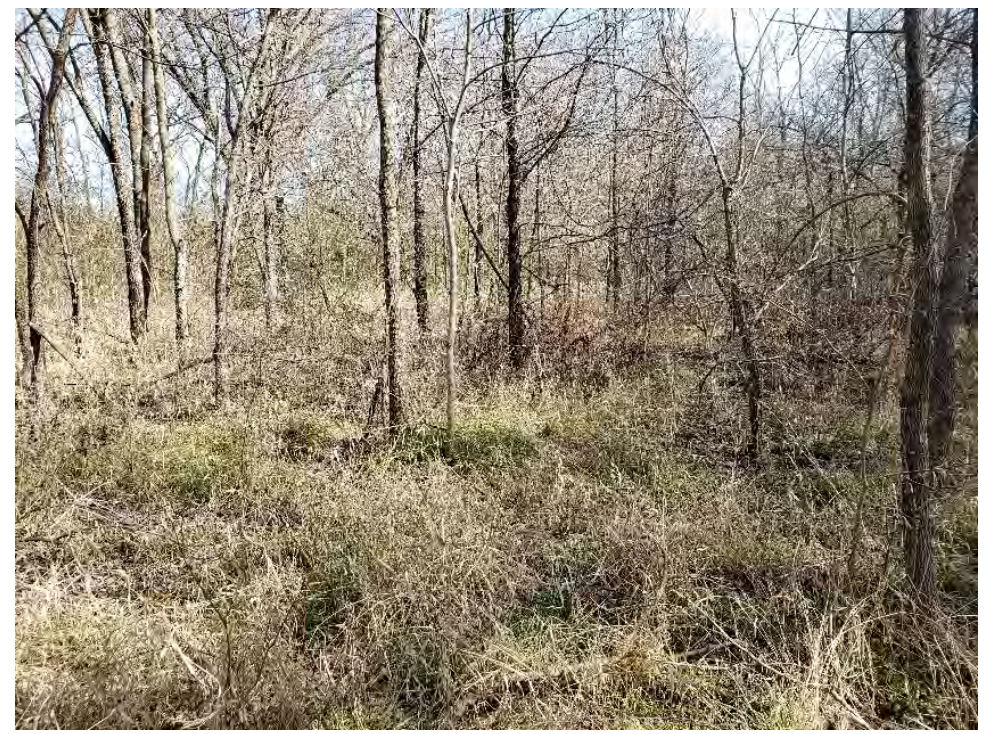

Photograph 15 - General setting, view to the south

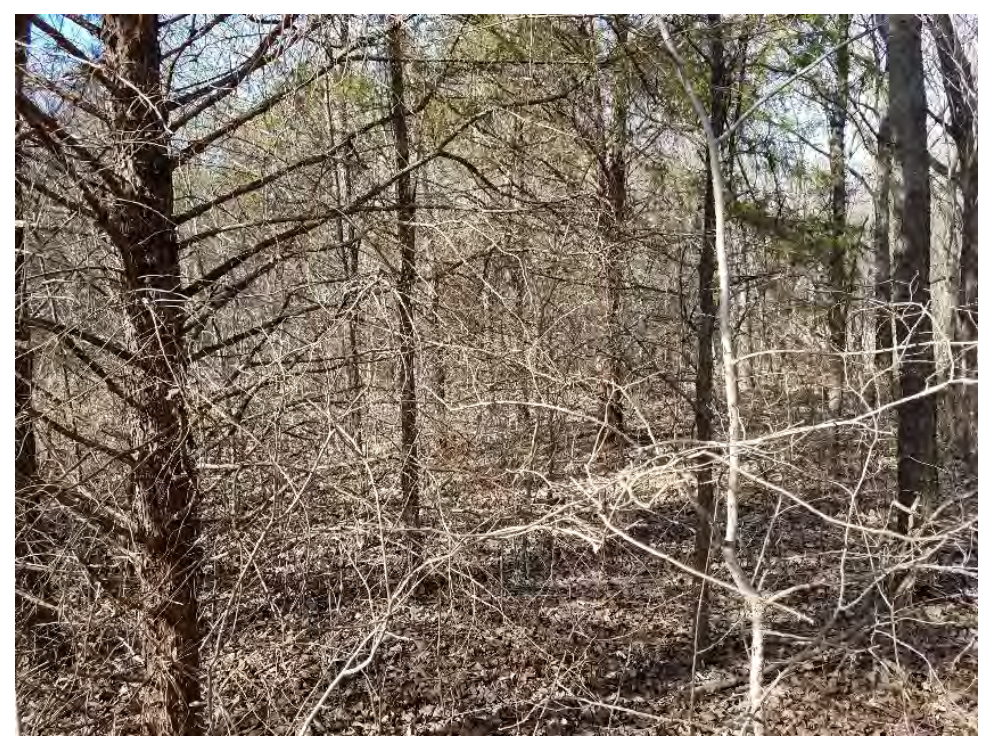

Photograph 17 - General setting, view to the north.

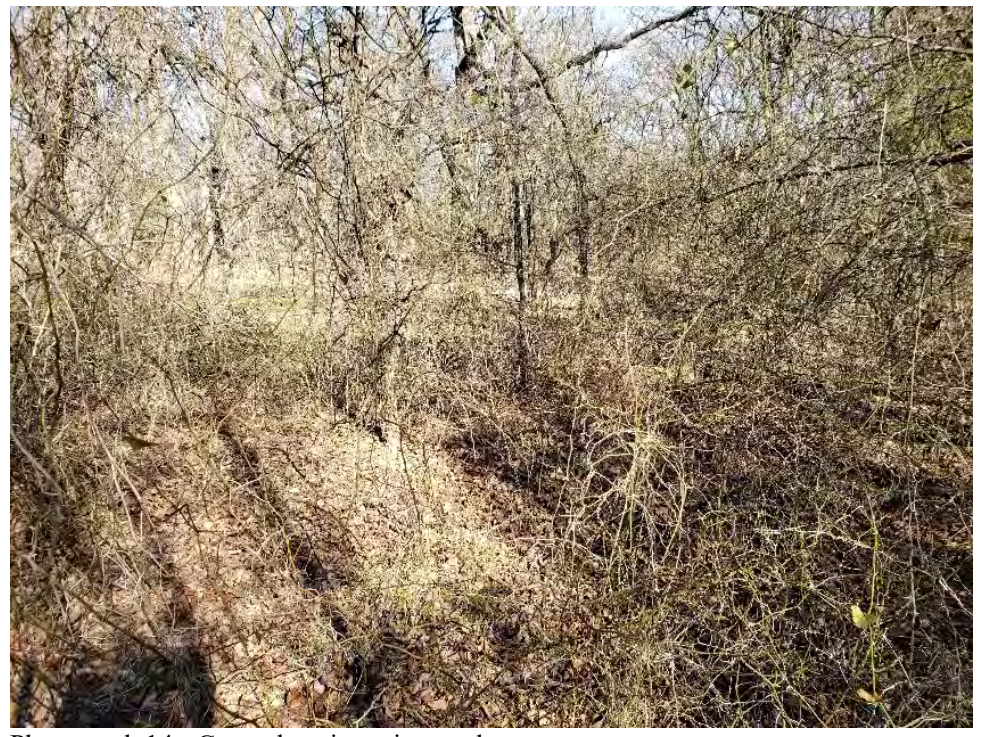

Photograph 14 - General setting, view to the east.

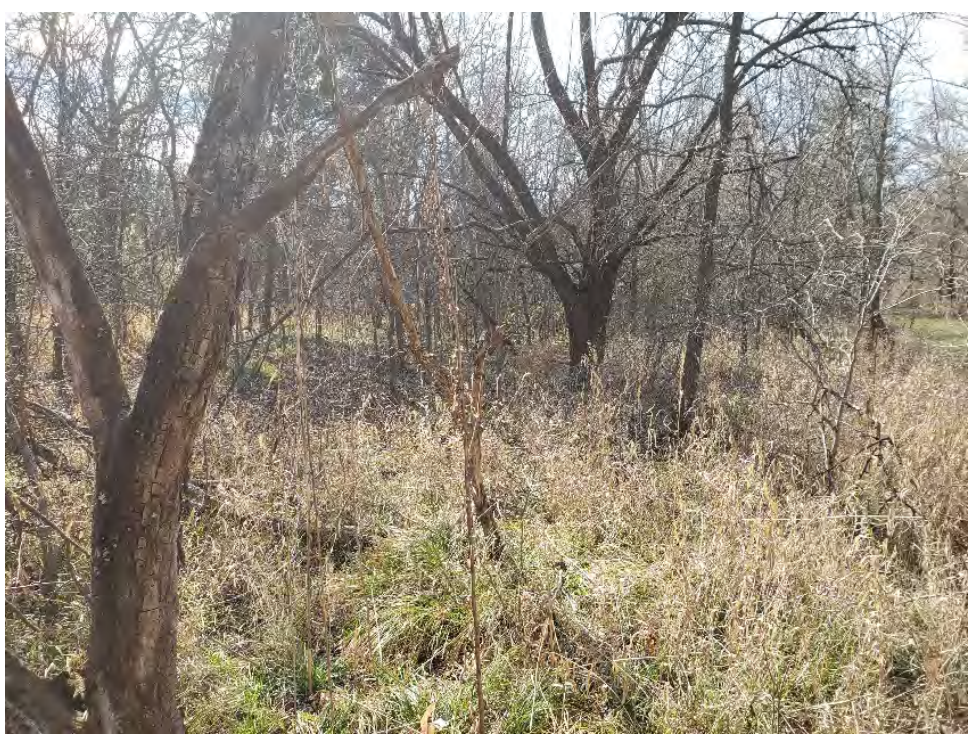

Photograph 16 - General setting, view to the west.

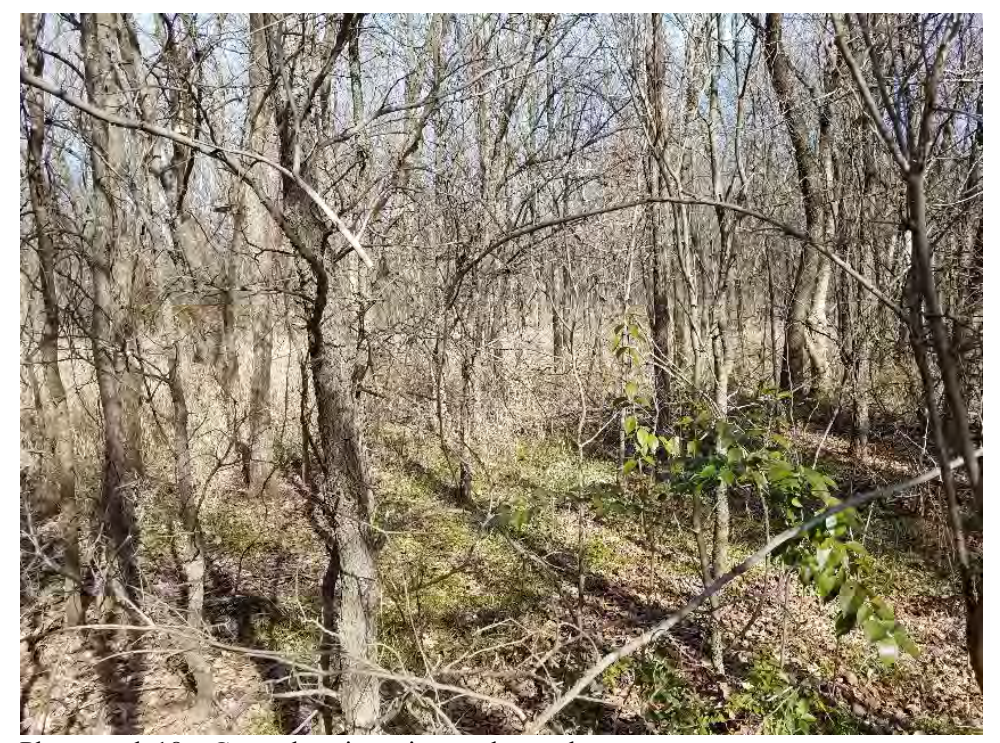

Photograph 18 - General setting, view to the northwest. 


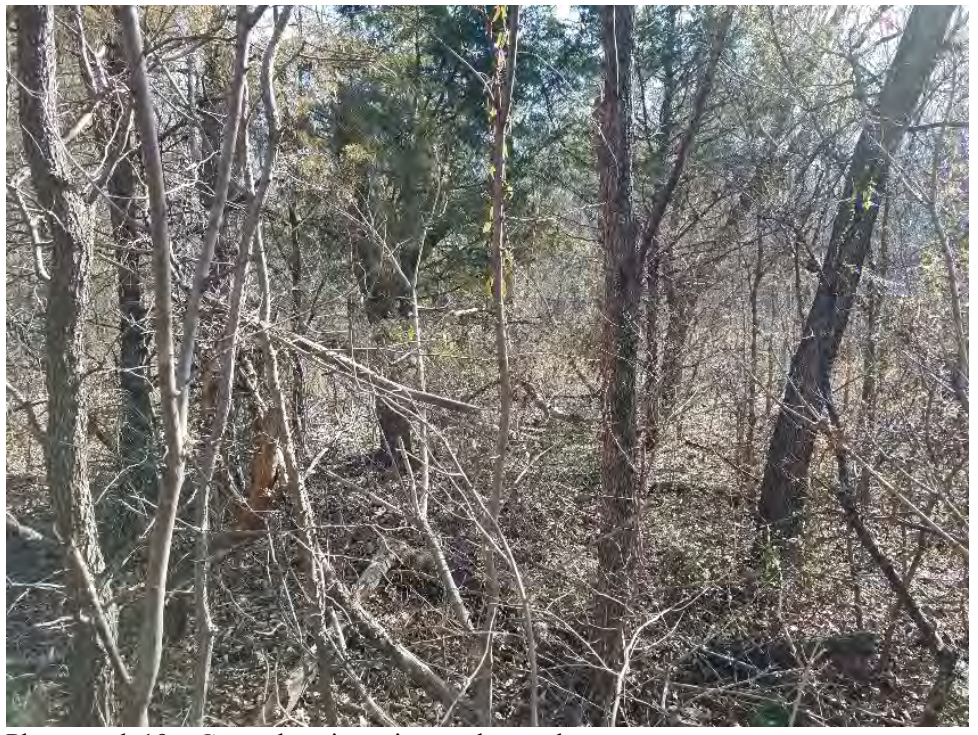

Photograph 19 - General setting, view to the southeast.

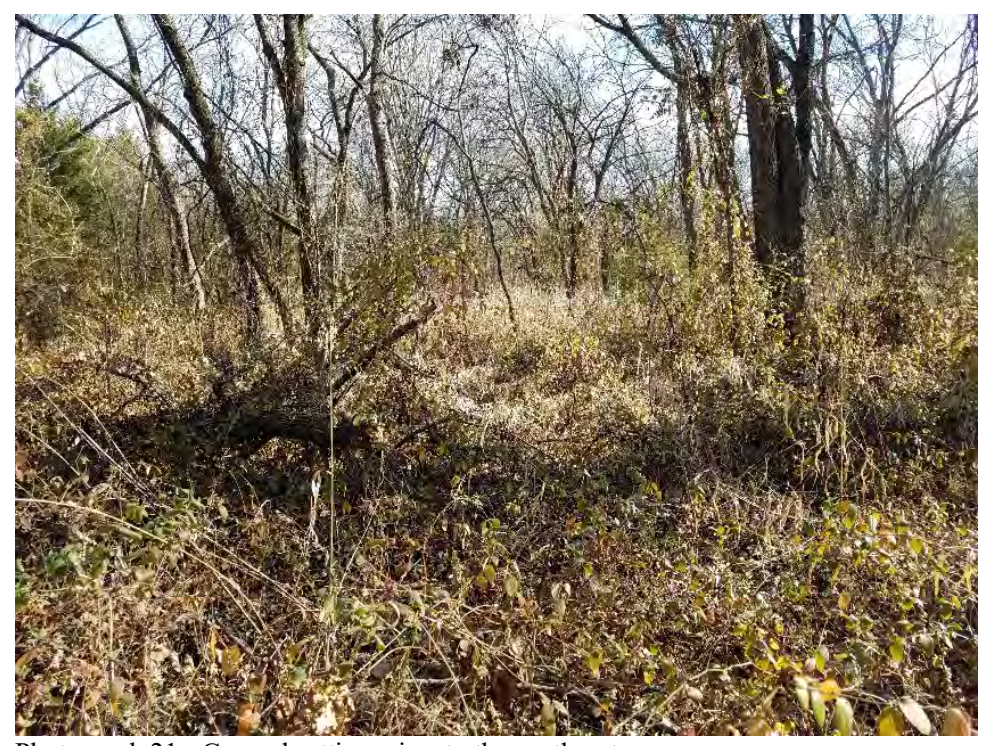

Photograph 21 - General setting, view to the southeast.

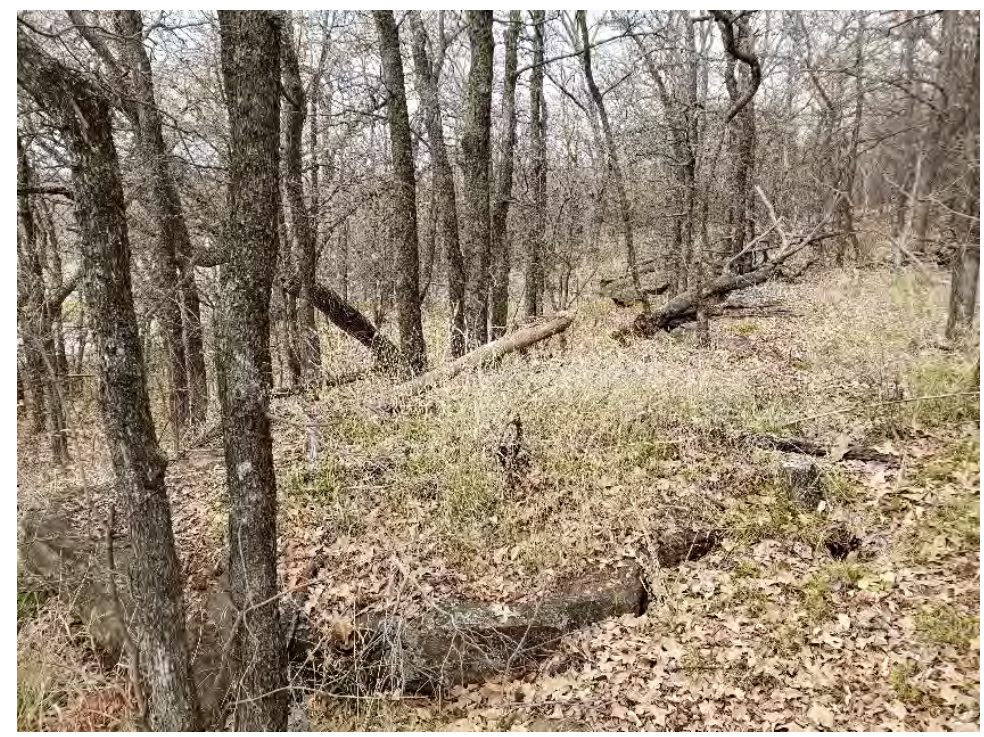

Photograph 23 - Exposed bedrock, view to the north.

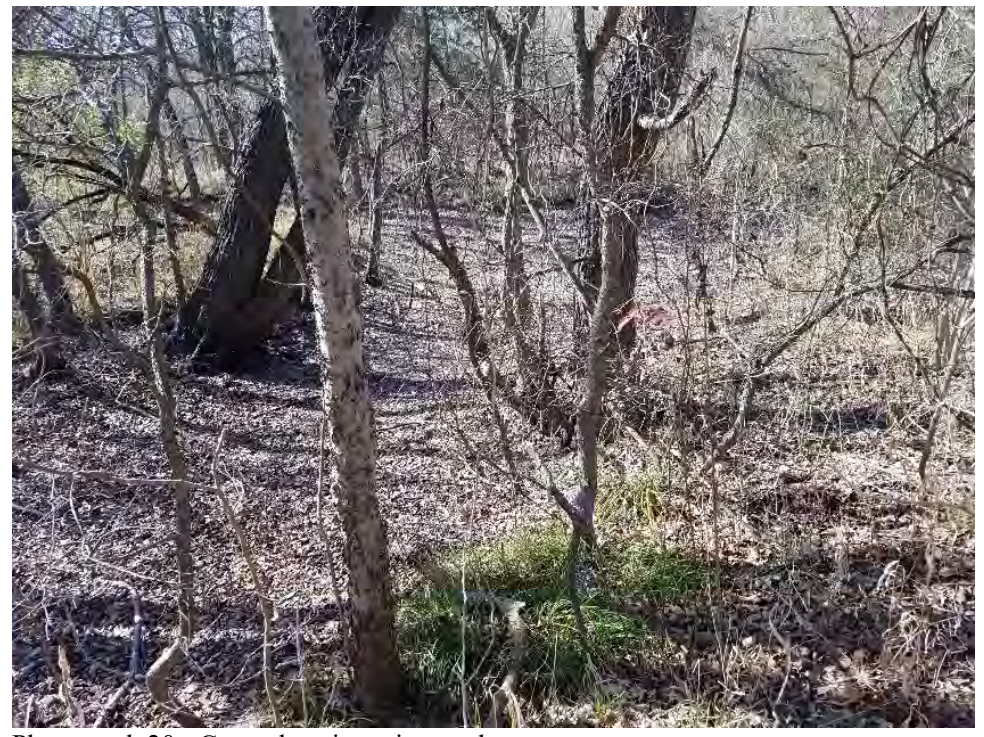

Photograph 20 - General setting, view to the west.

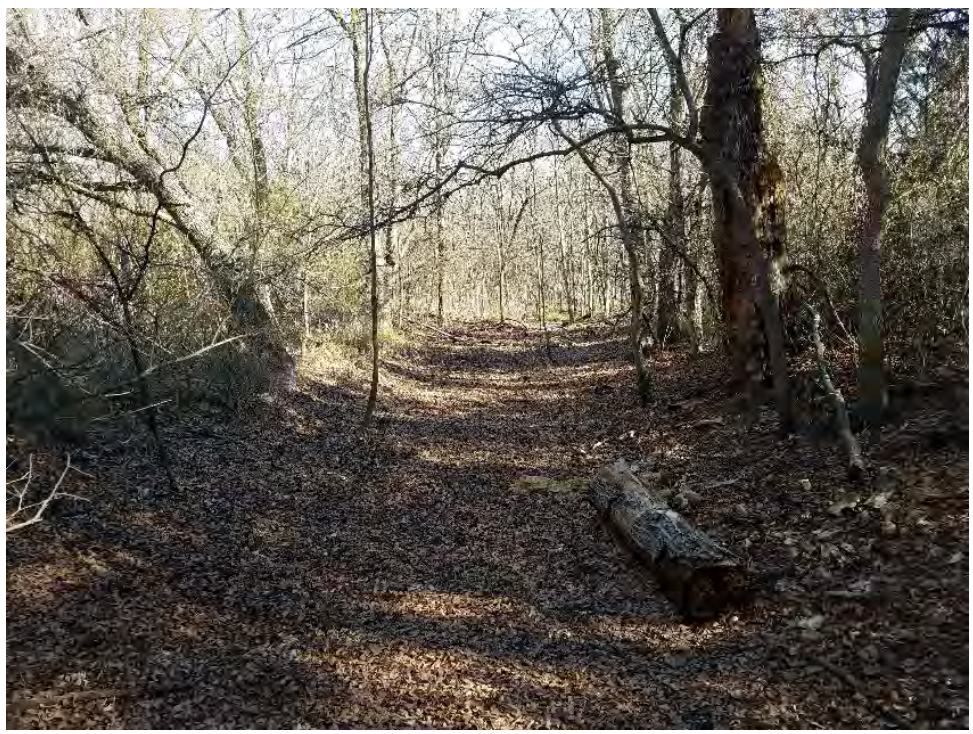

Photograph 22 - General setting, view to the east.

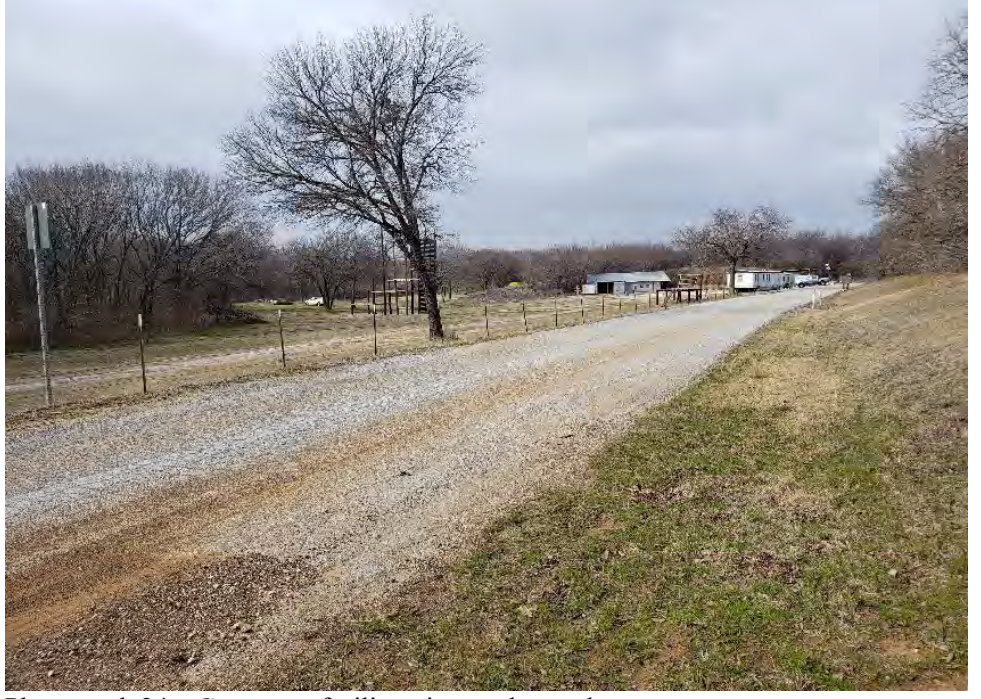

Photograph 24 - Gun range facility, view to the north. 


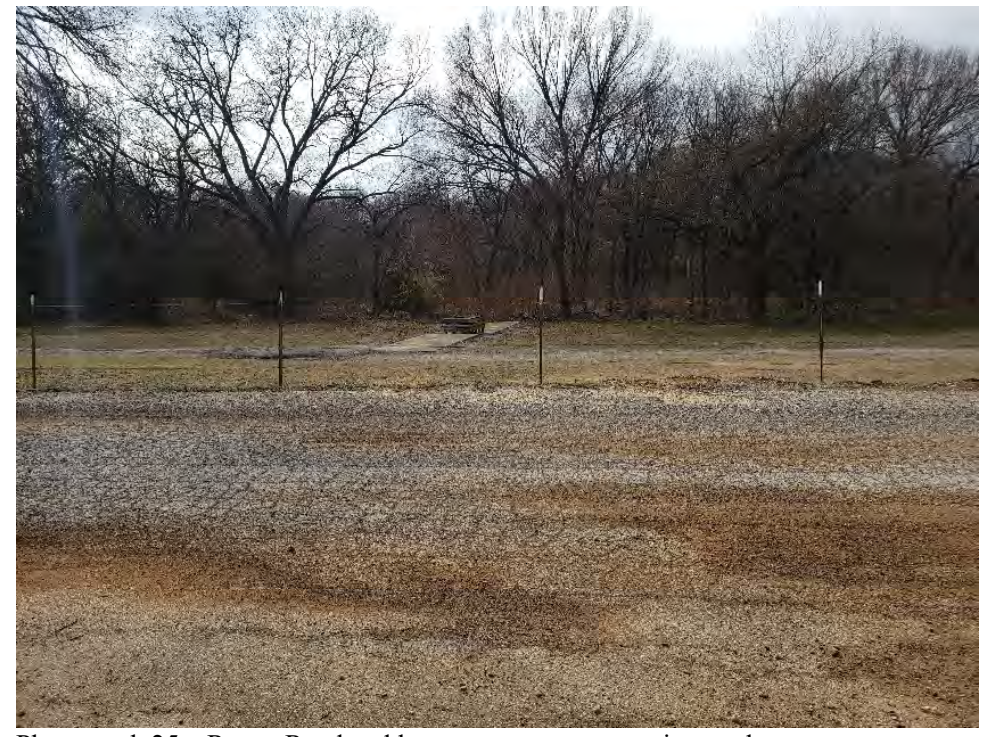

Photograph 25 - Range Road and long-range gun range, view to the west.

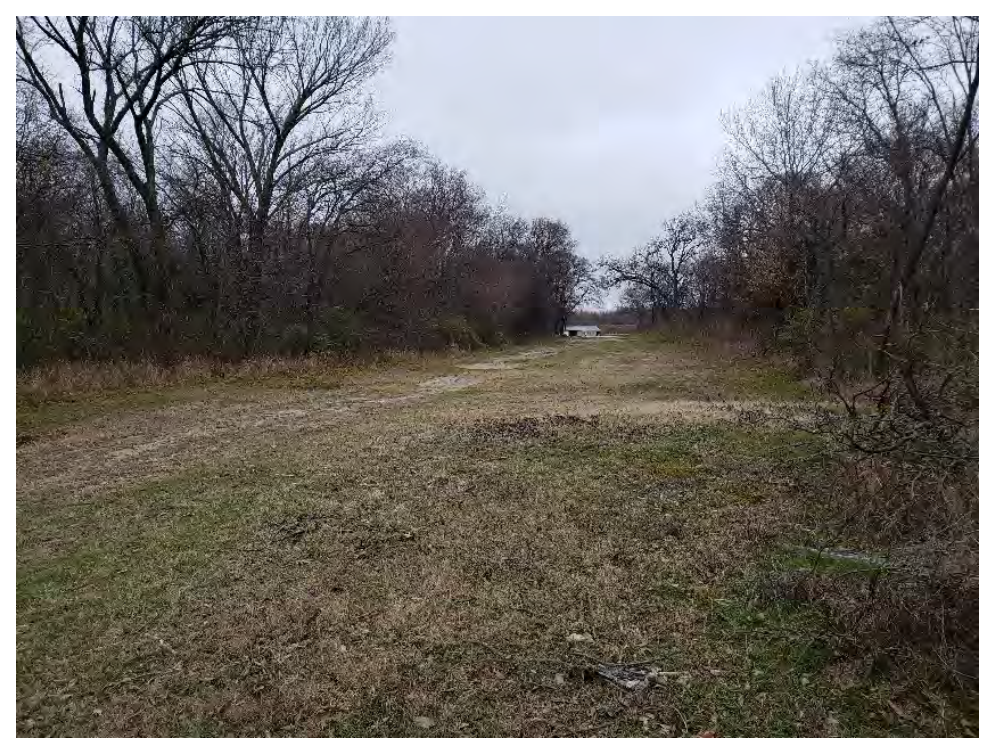

Photograph 27 - Long-range gun range, view to the northwest.

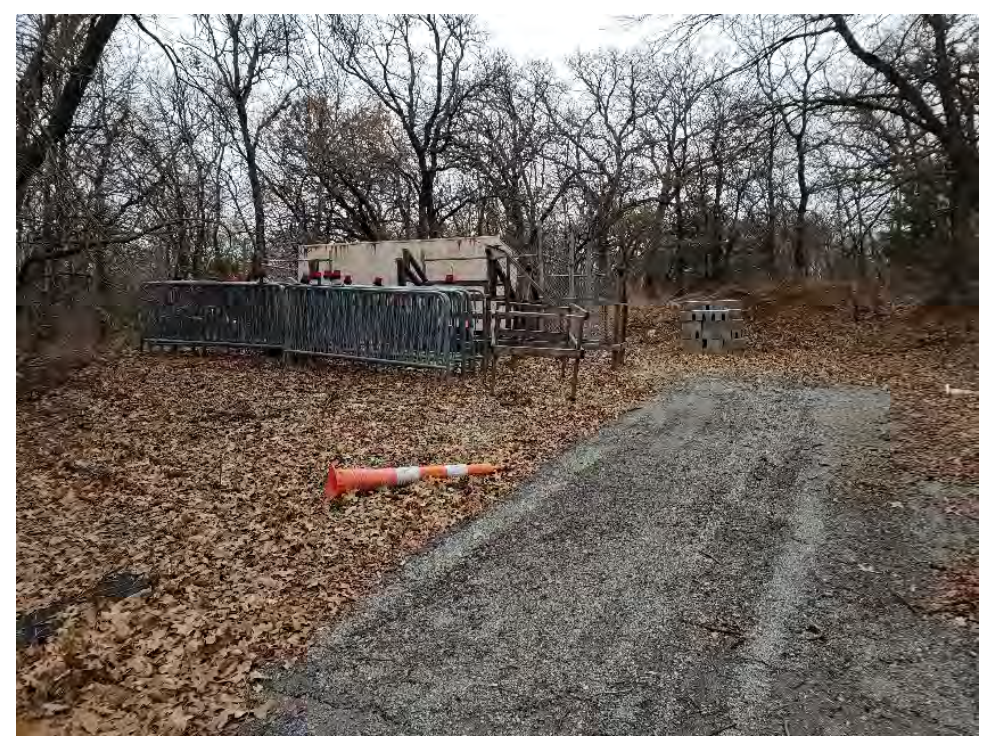

Photograph 29 - Storage area, view to the east.

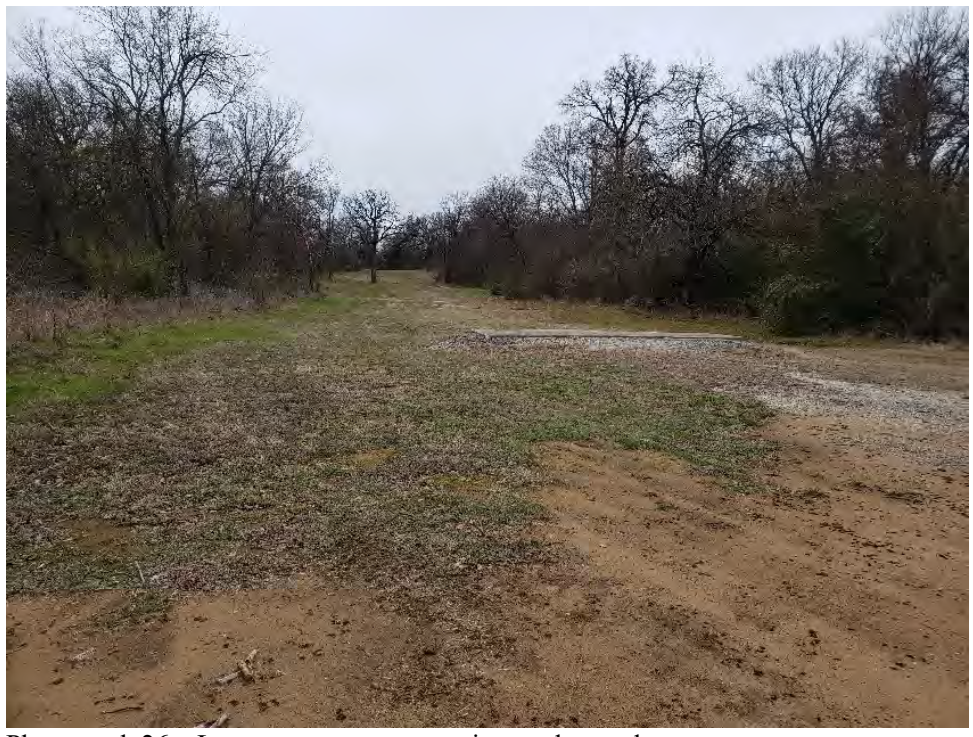

Photograph 26 - Long-range gun range, view to the southeast.

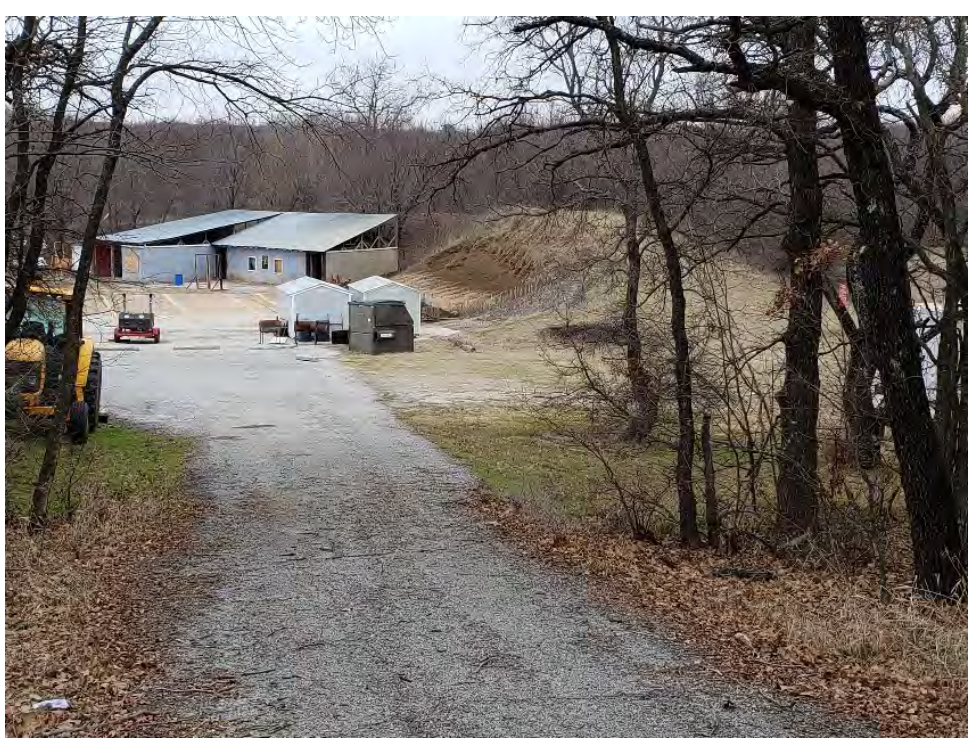

Photograph 28 - Gun range facility, view to the west.

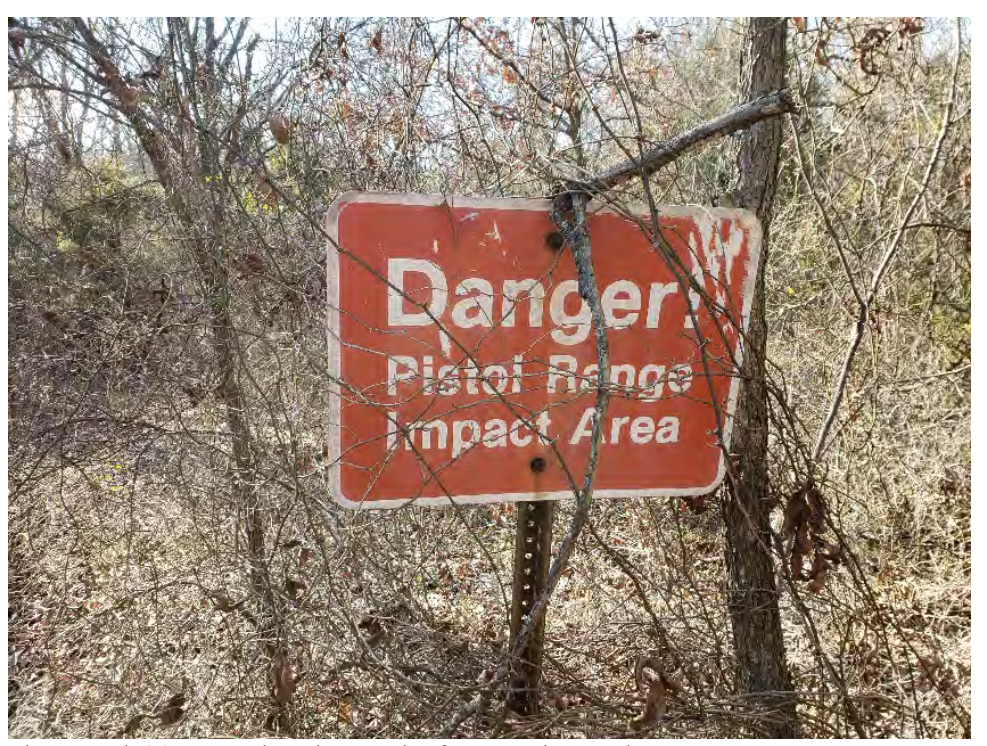

Photograph 30 - Warning sign north of range, view to the west. 


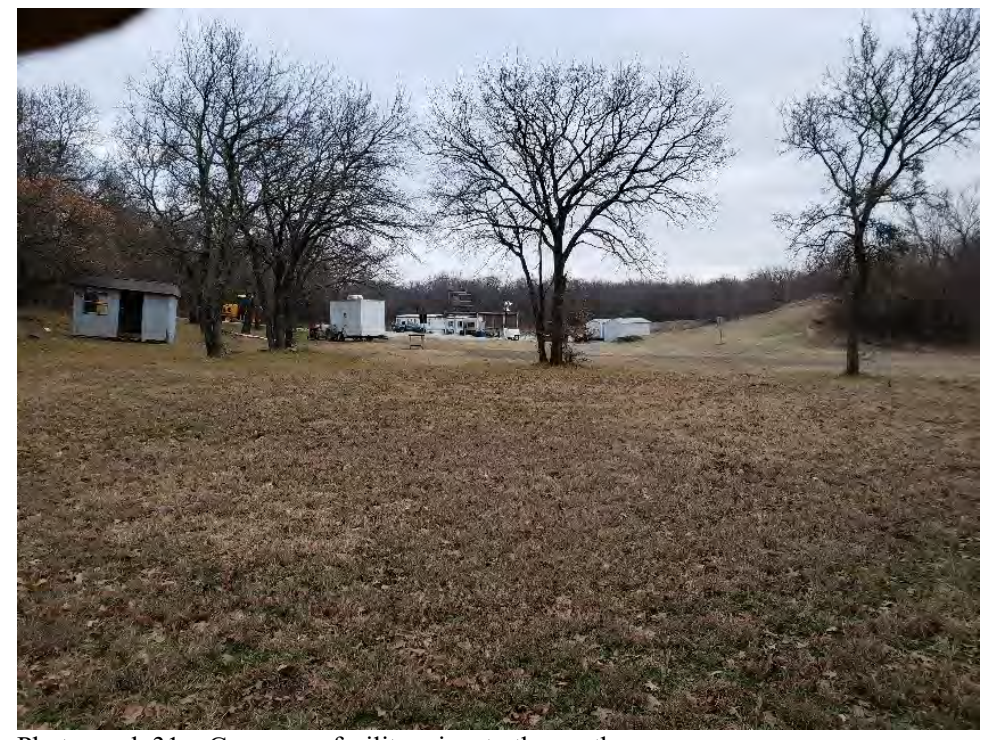

Photograph 31 - Gun range facility, view to the south.

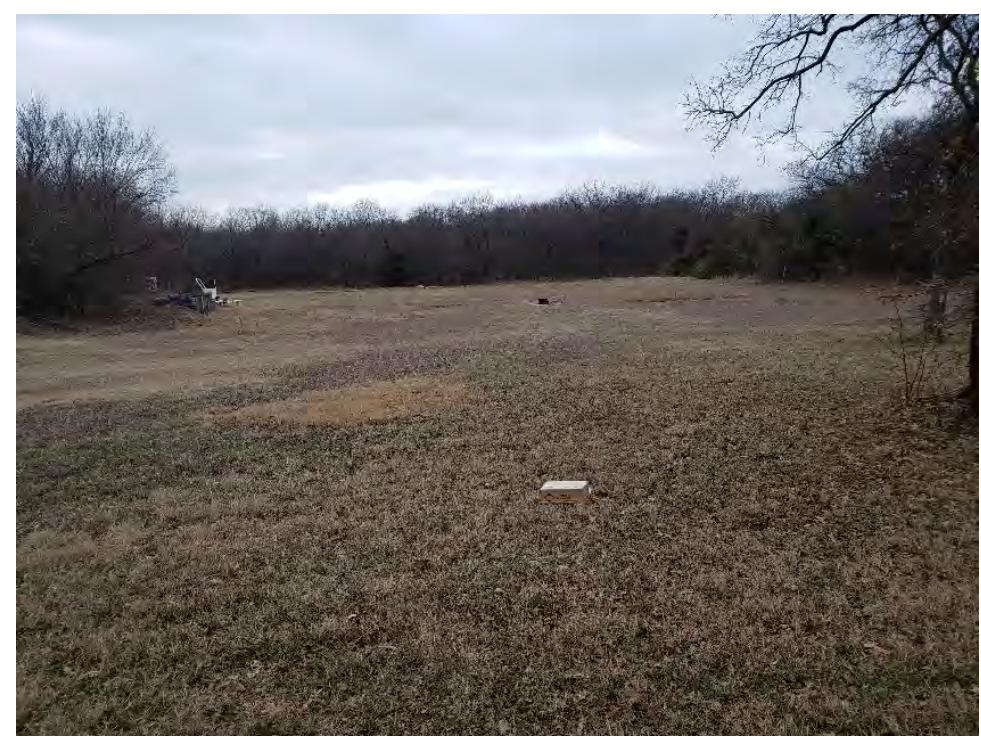

Photograph 33 - Gun range, view to the west.

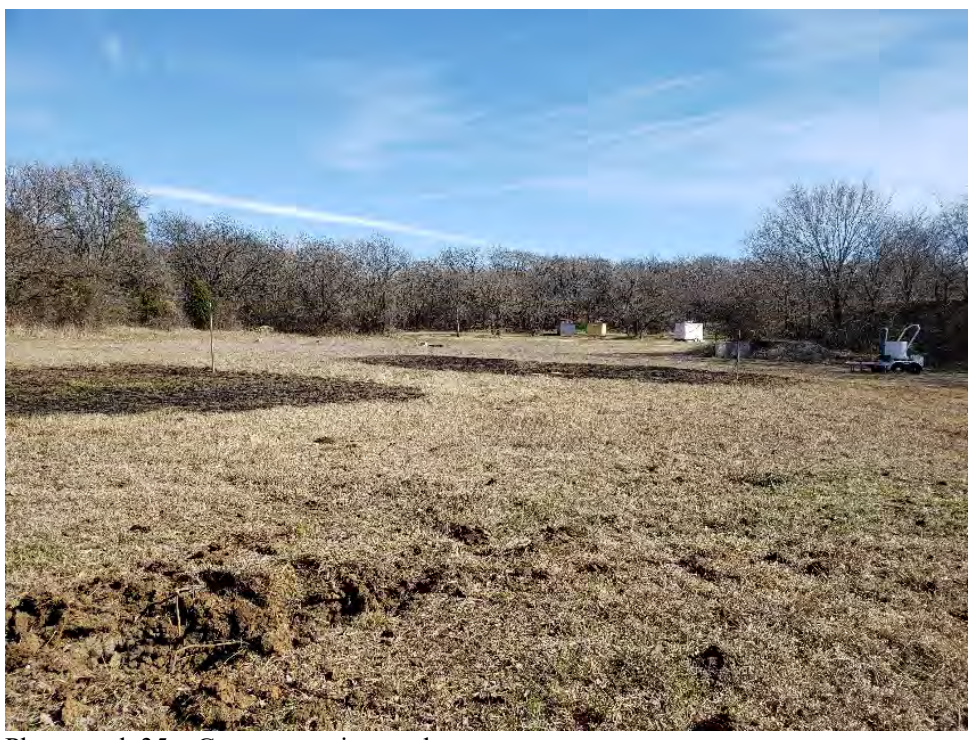

Photograph 35 - Gun range, view to the east.

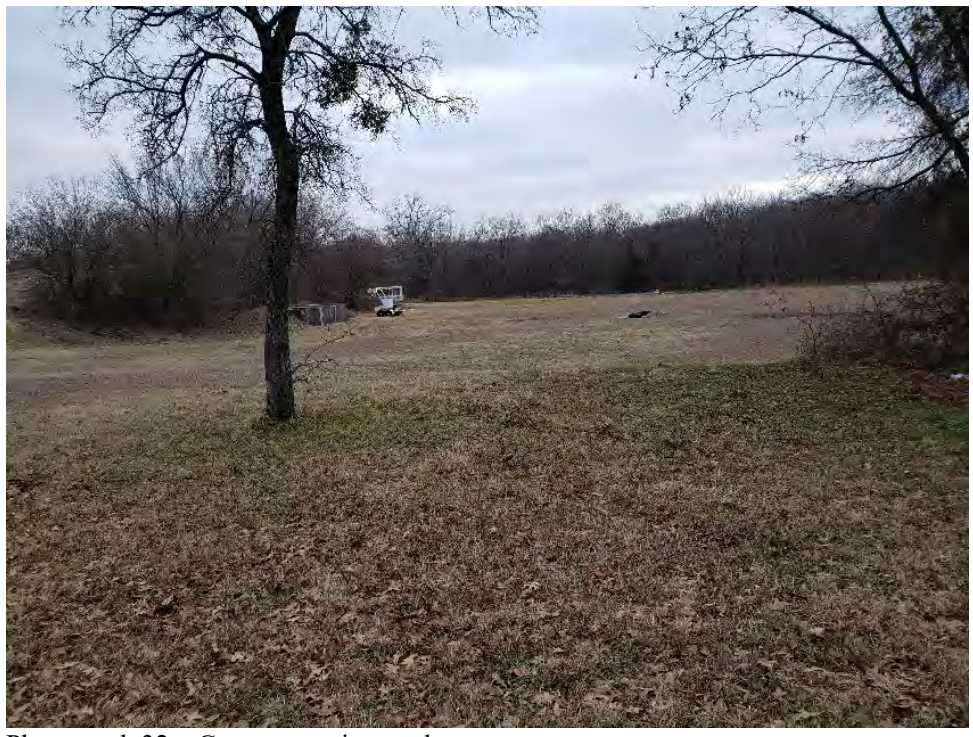

Photograph 32 - Gun range, view to the west.

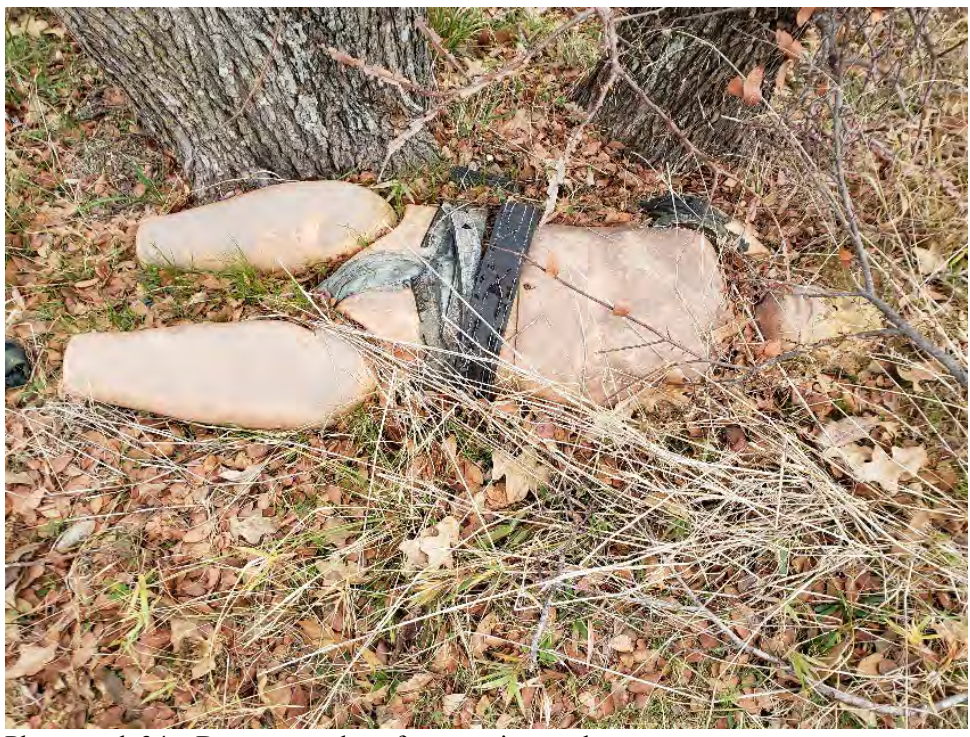

Photograph 34 - Dummy at edge of range, view to the east.

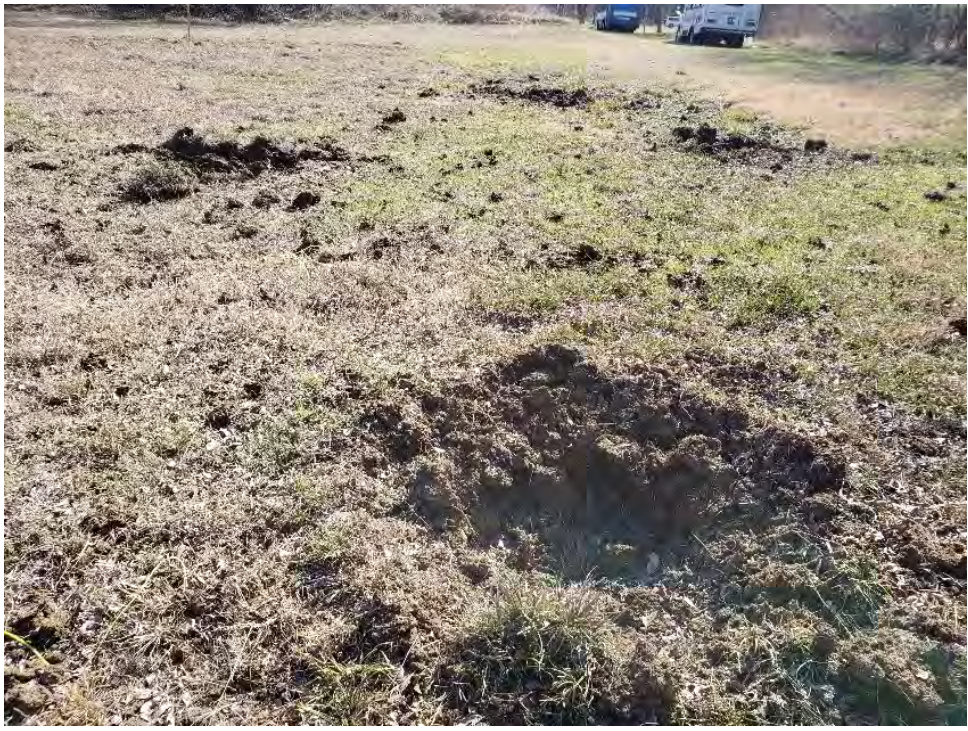

Photograph 36 - Recently excavated holes, view to the south. 


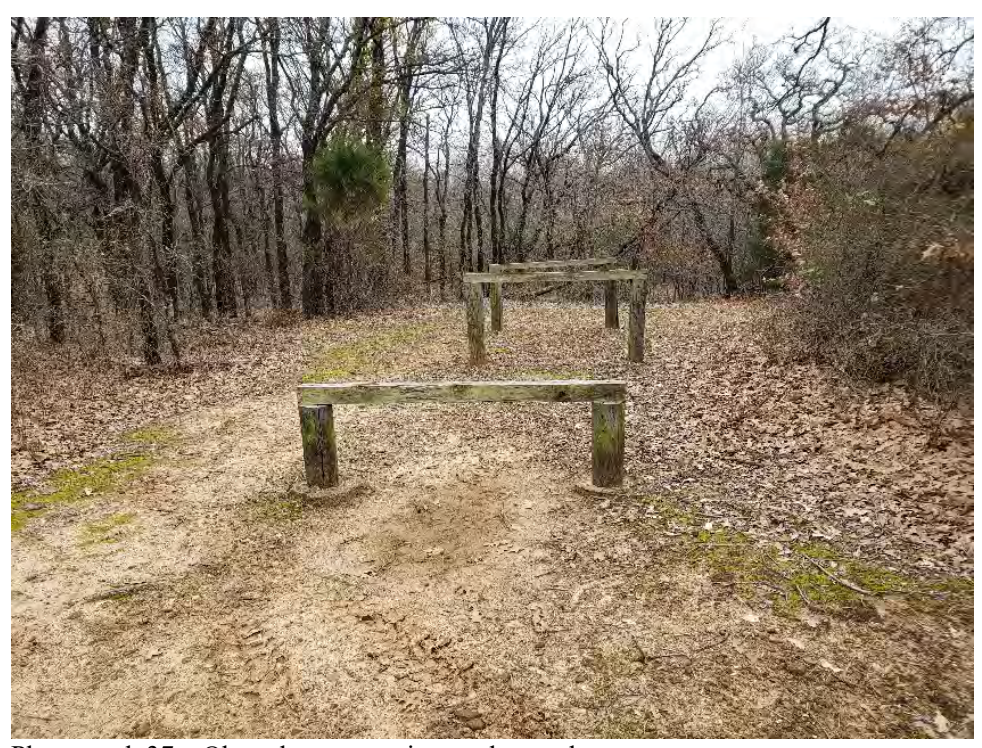

Photograph 37 - Obstacle course, view to the south.

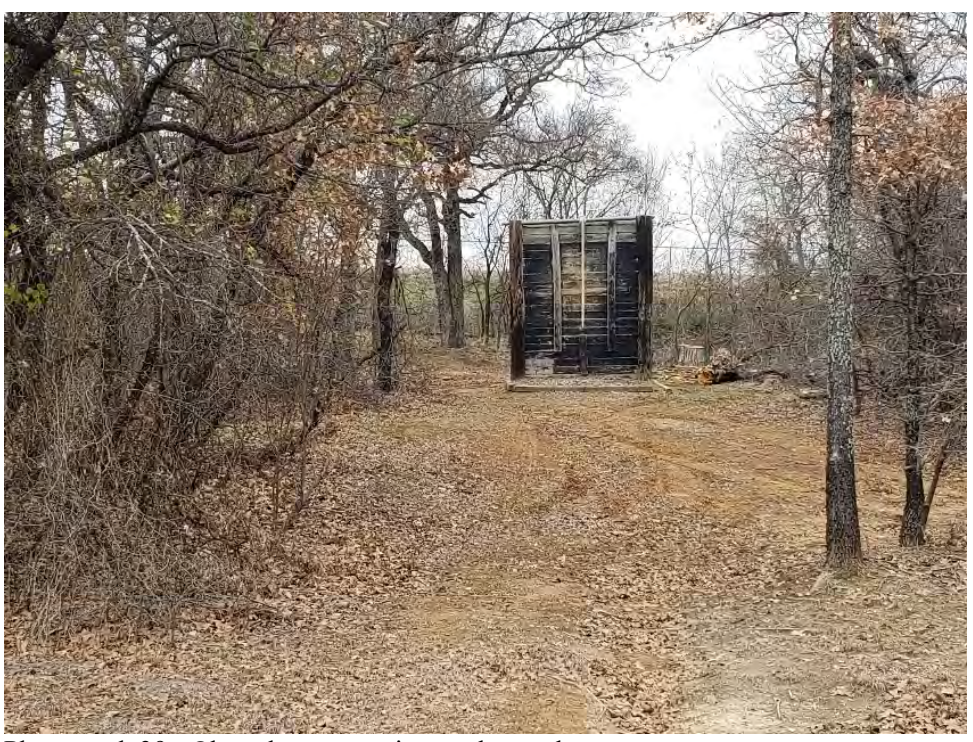

Photograph 39 - Obstacle course, view to the north.

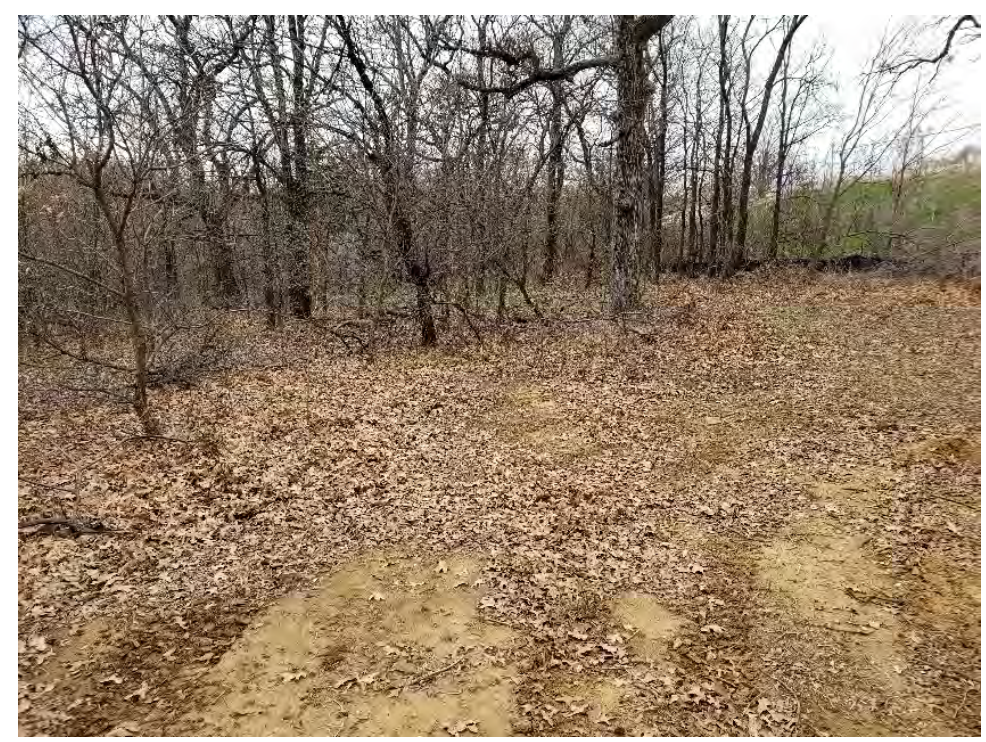

Photograph 41 - Obstacle course trail, view to the west.

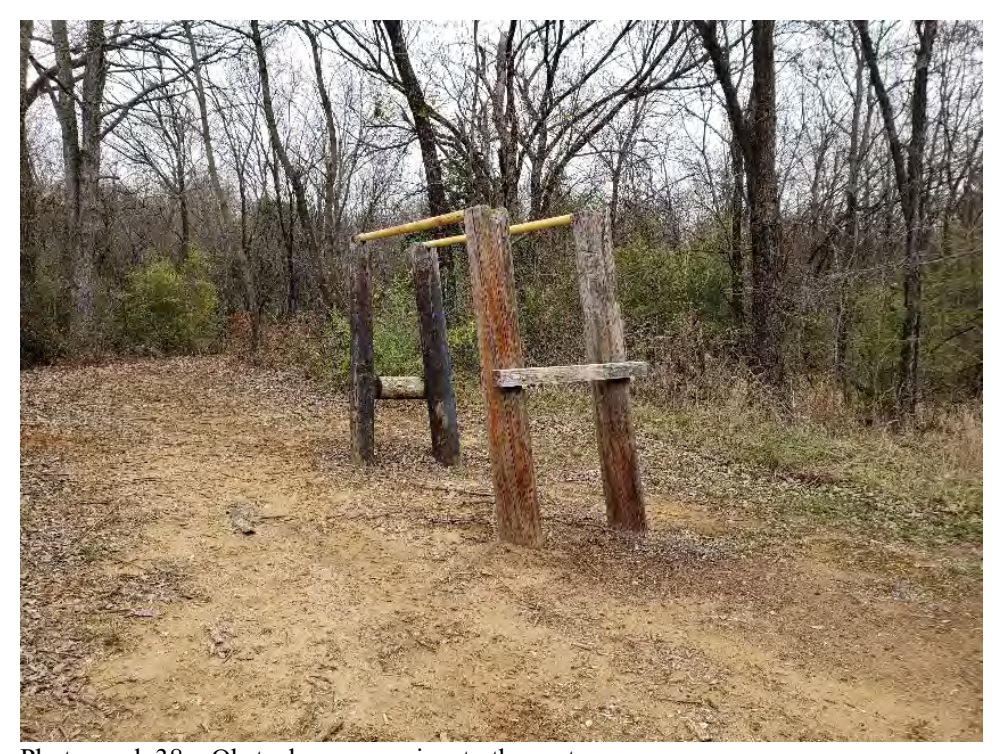

Photograph 38 - Obstacle course, view to the east.

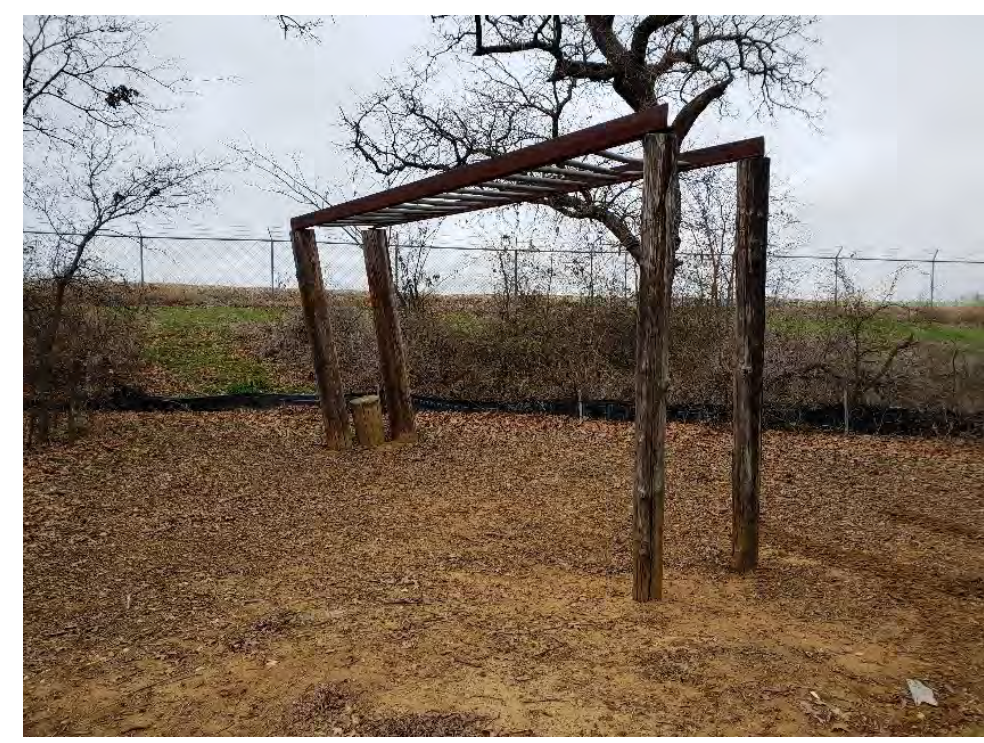

Photograph 40 - Obstacle course, view to the north.

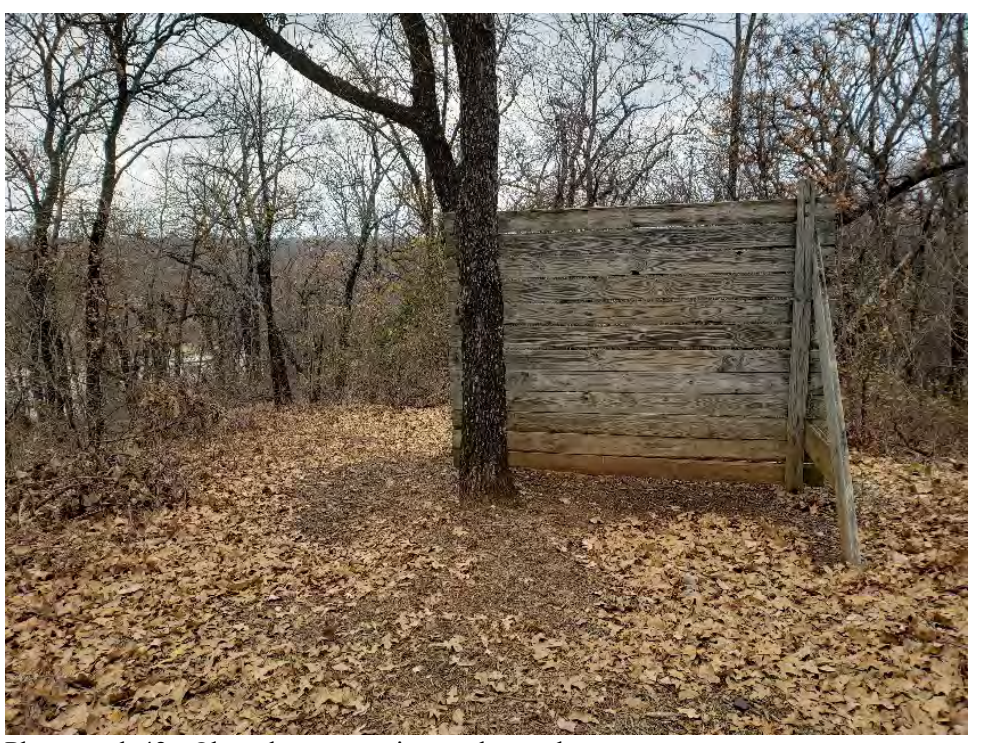

Photograph 42 - Obstacle course, view to the north. 


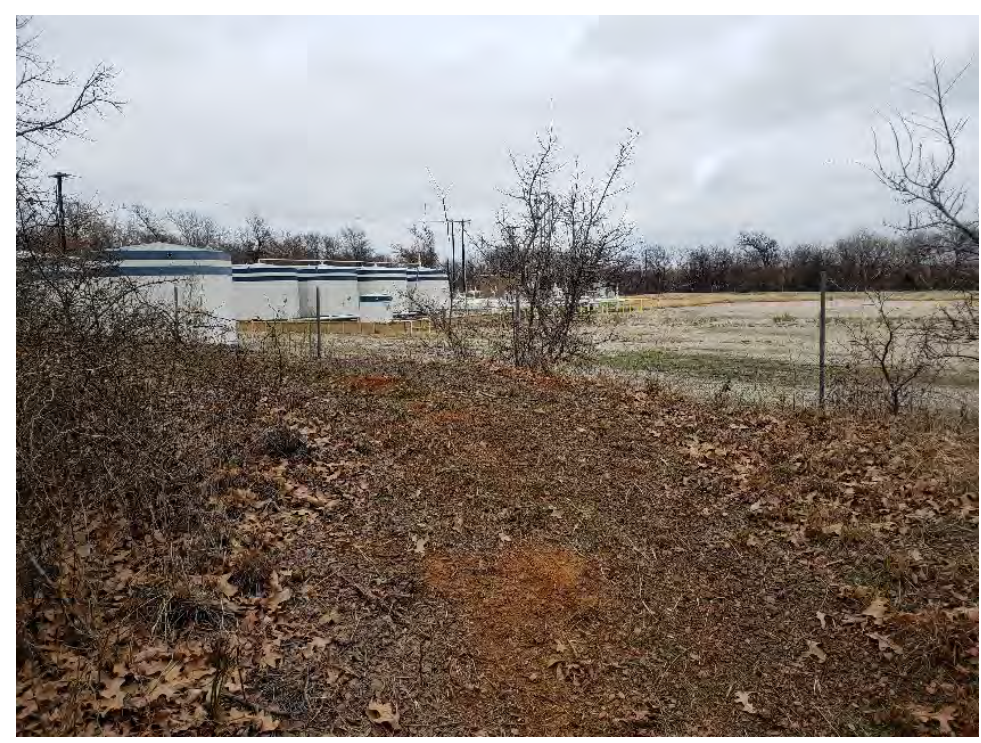

Photograph 43 - Well pad site, view to the north.

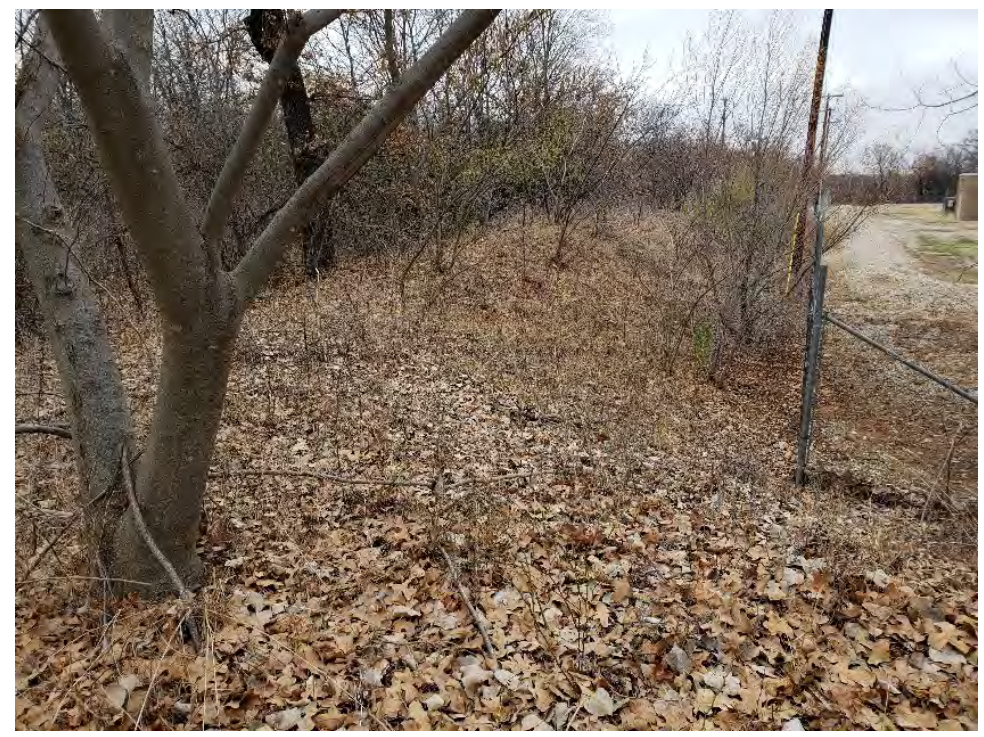

Photograph 45 - Earthen berm around pad site, view to the east.

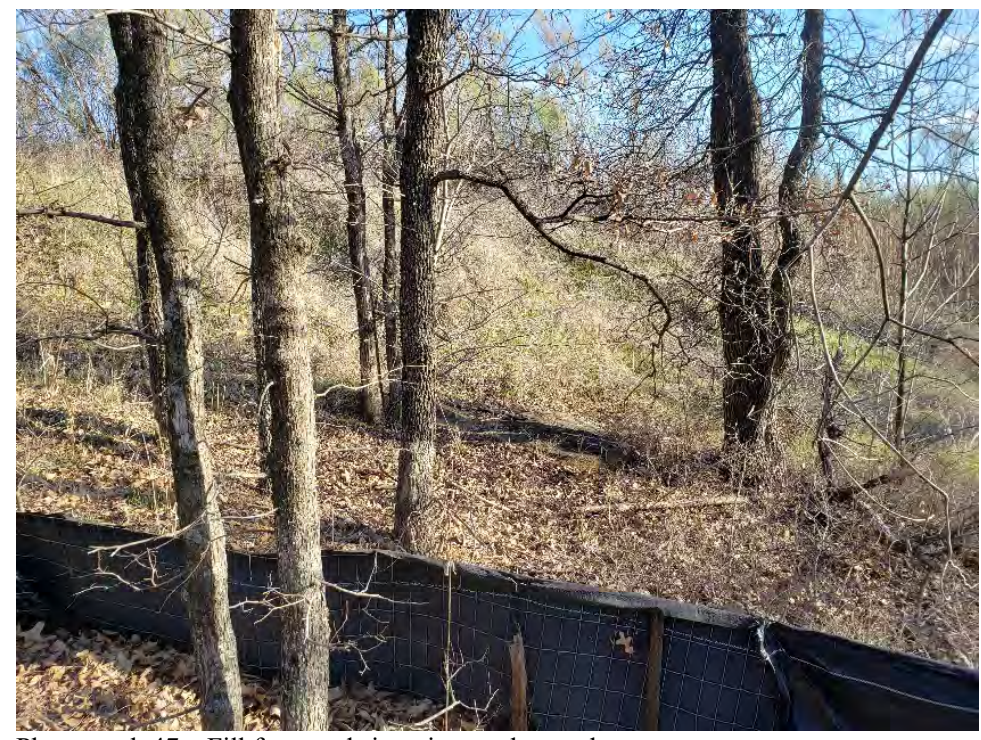

Photograph 47 - Fill from pad site, view to the south.

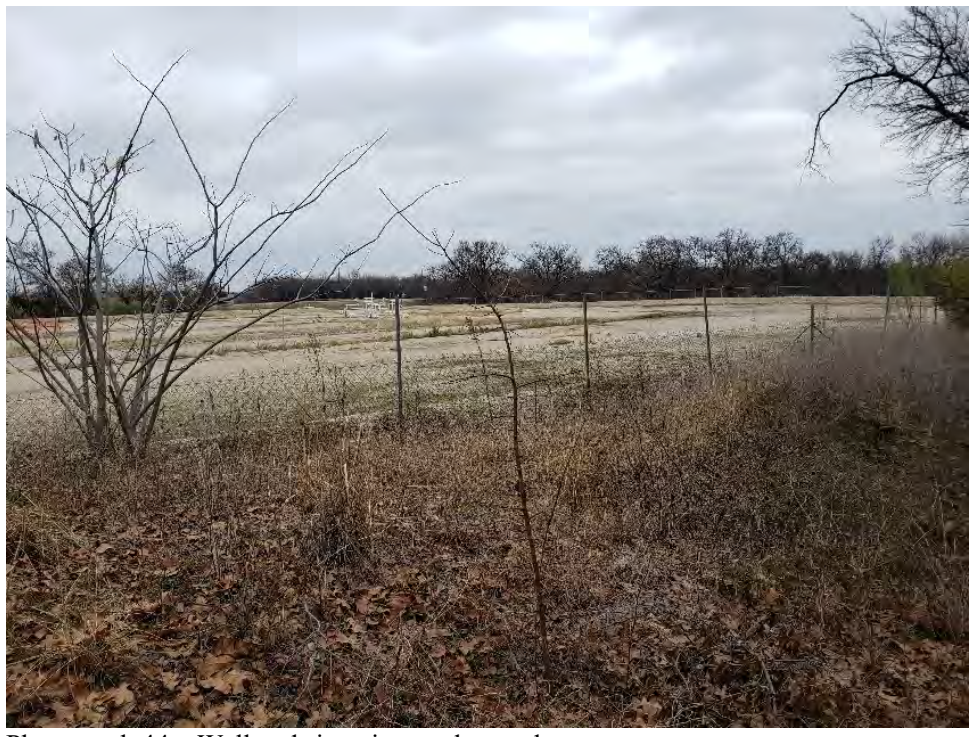

Photograph 44 - Well pad site, view to the south.

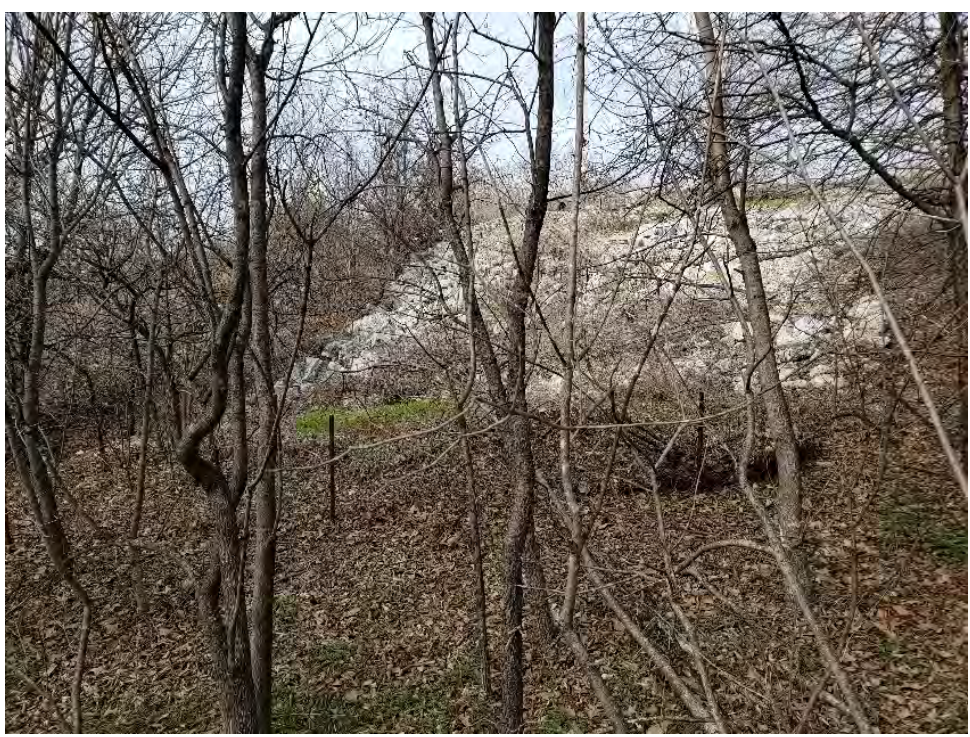

Photograph 46 - Rock rip-rap, view to the west.

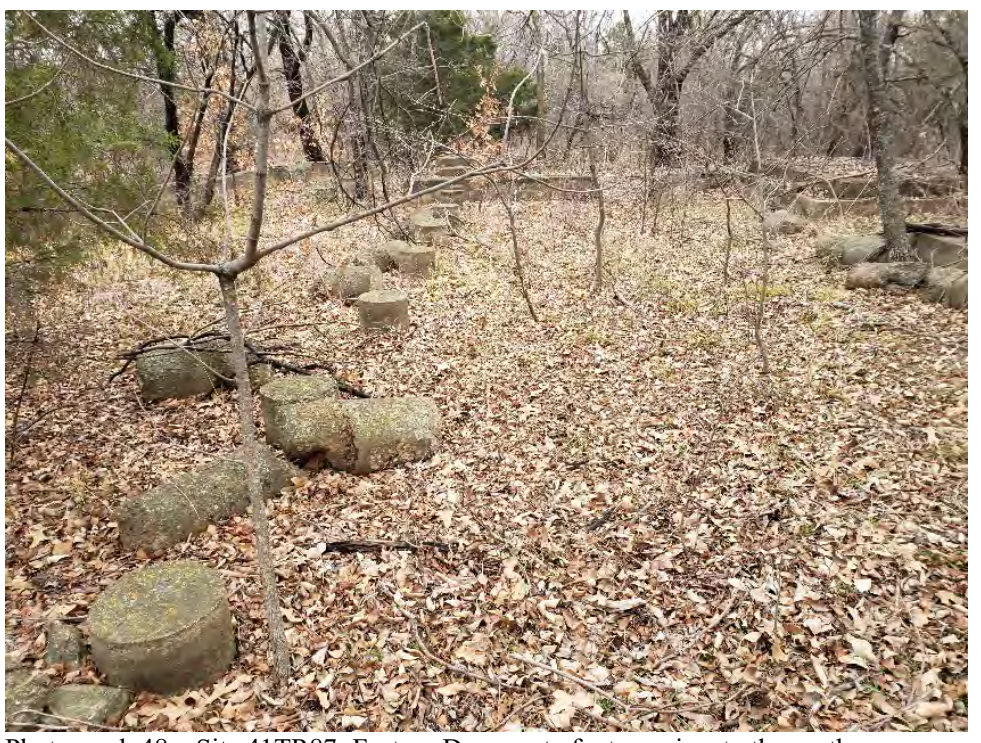

Photograph 48 - Site 41TR87: Feature D concrete footers, view to the north. 


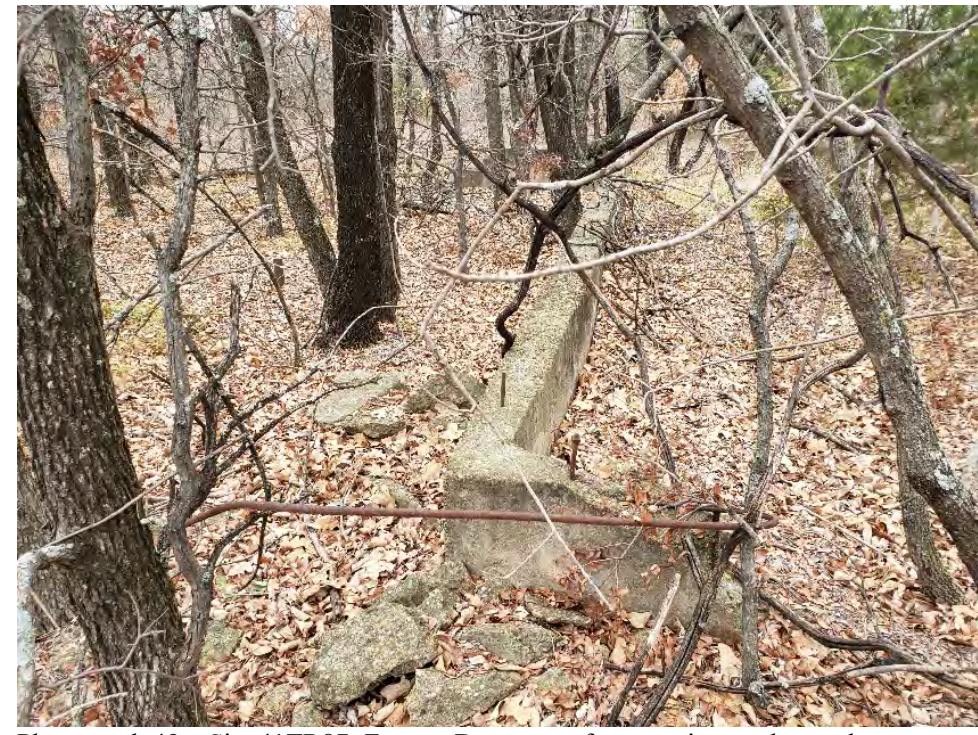

Photograph 49 - Site 41TR87: Feature D concrete footers, view to the north.

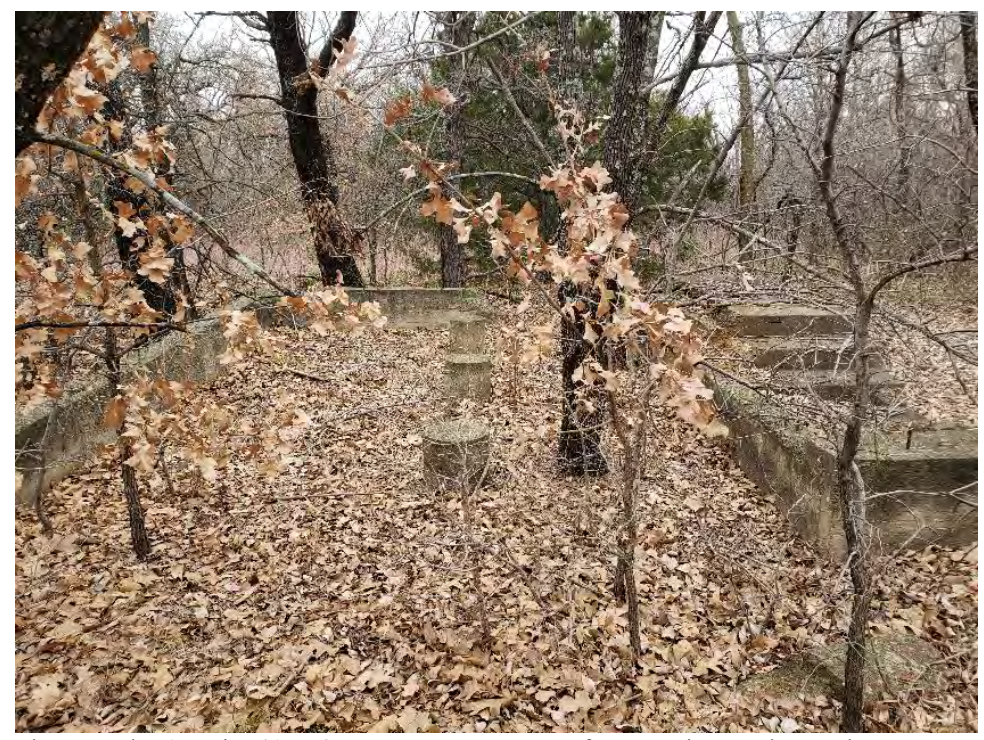

Photograph 51 - Site 41TR87: Feature D concrete footers, view to the north.

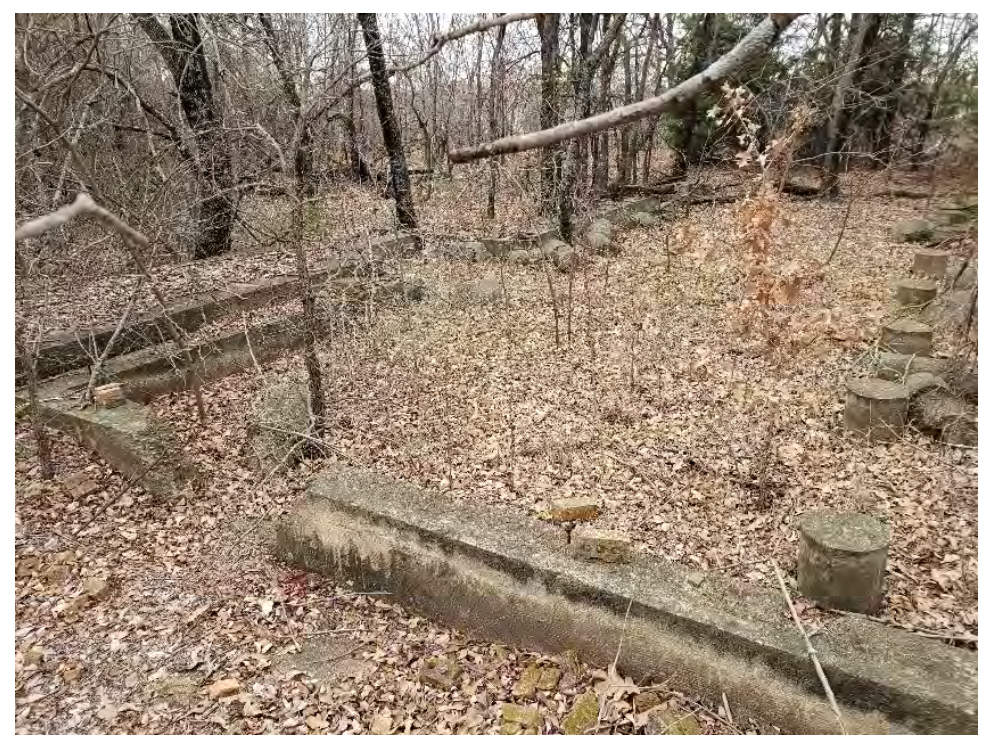

Photograph 53 - Site 41TR87: Feature D concrete footers, view to the southeast.
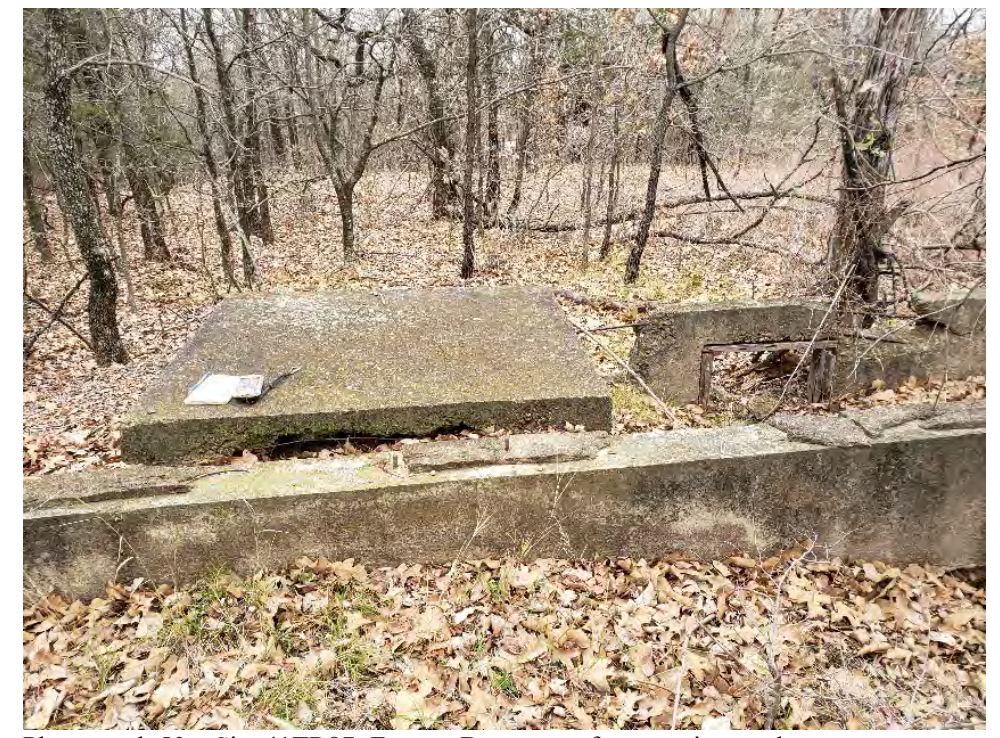
Photograph 50 - Site 41TR87: Feature D concrete footers, view to the west.

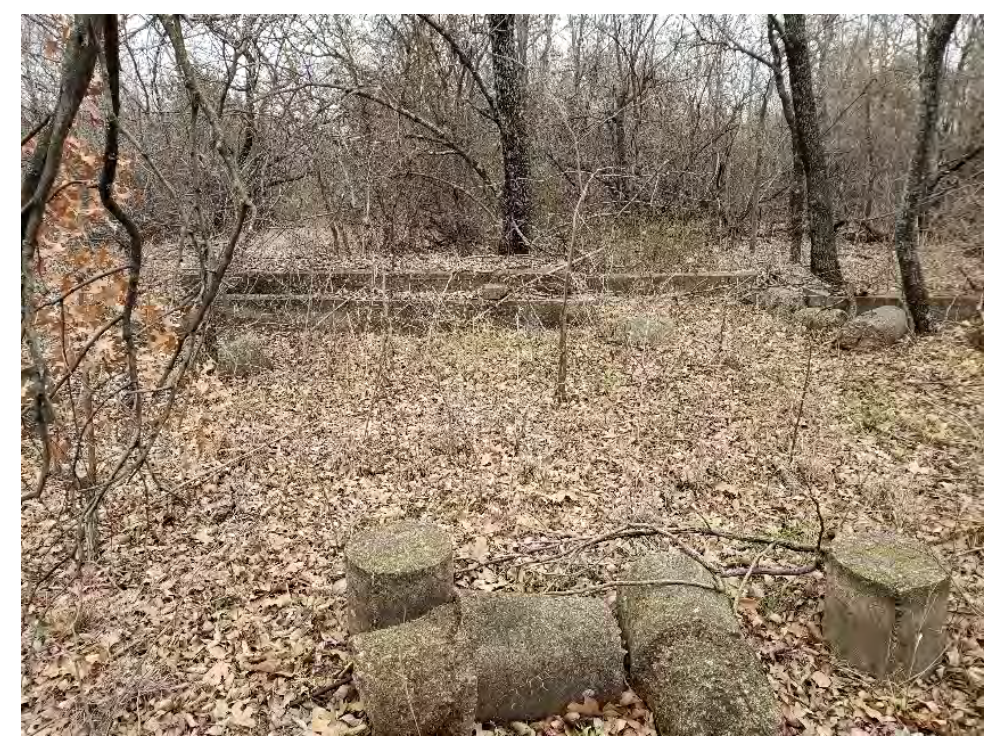
Photograph 52 - Site 41TR87: Feature D concrete footers, view to the east.

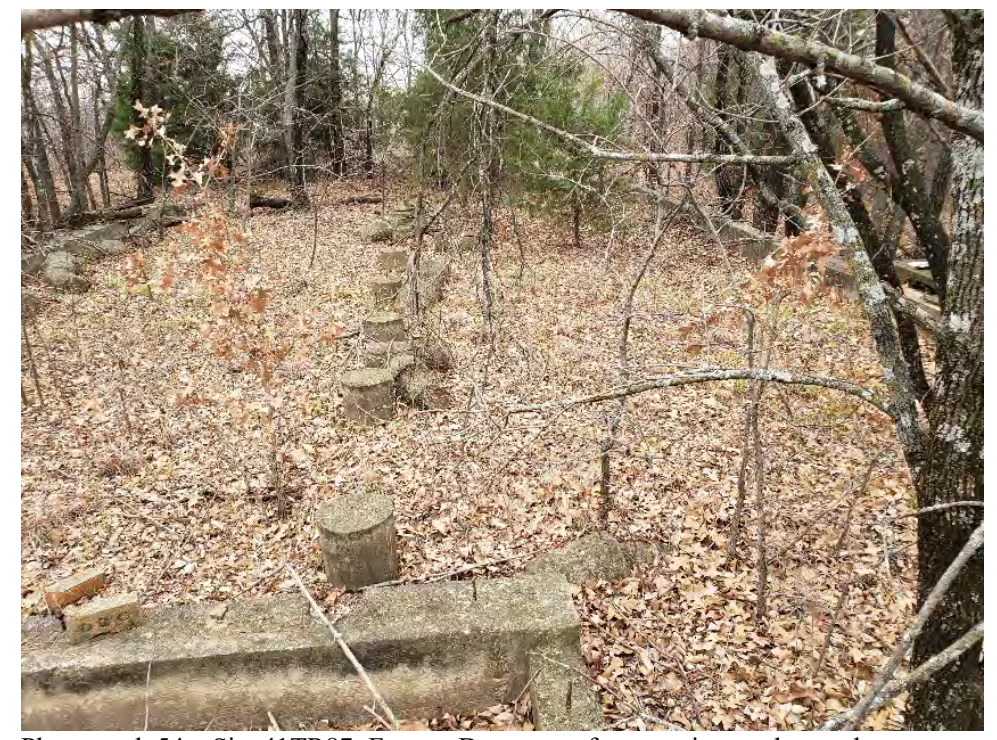

Photograph 54 - Site 41TR87: Feature D concrete footers, view to the south. 


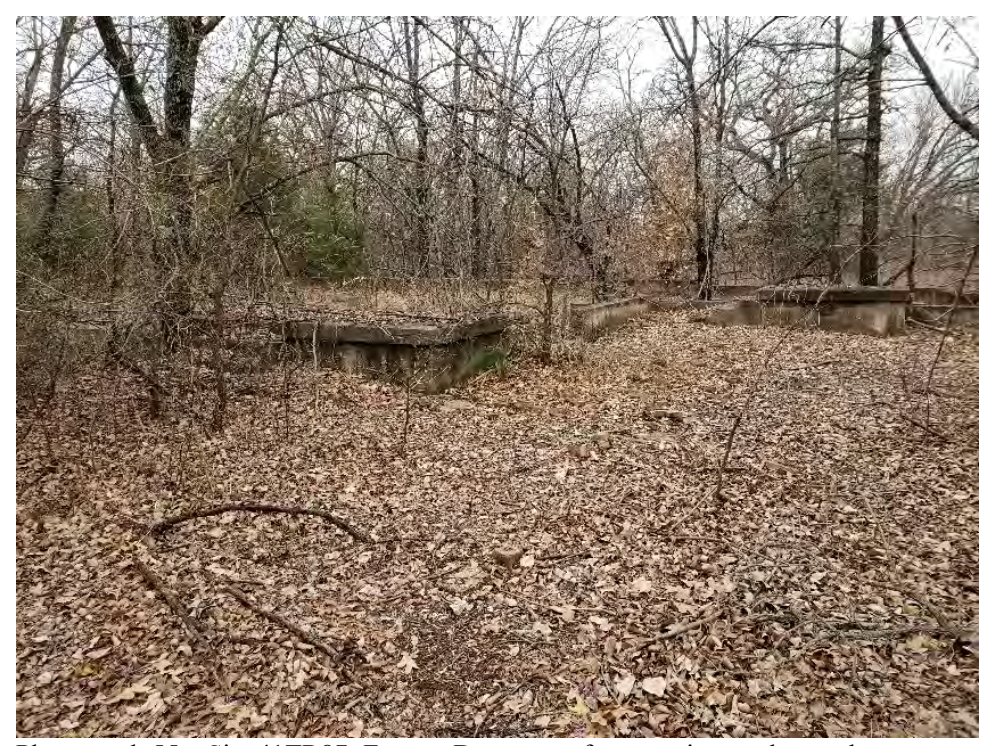

Photograph 55 - Site 41TR87: Feature D concrete footers, view to the southwest.

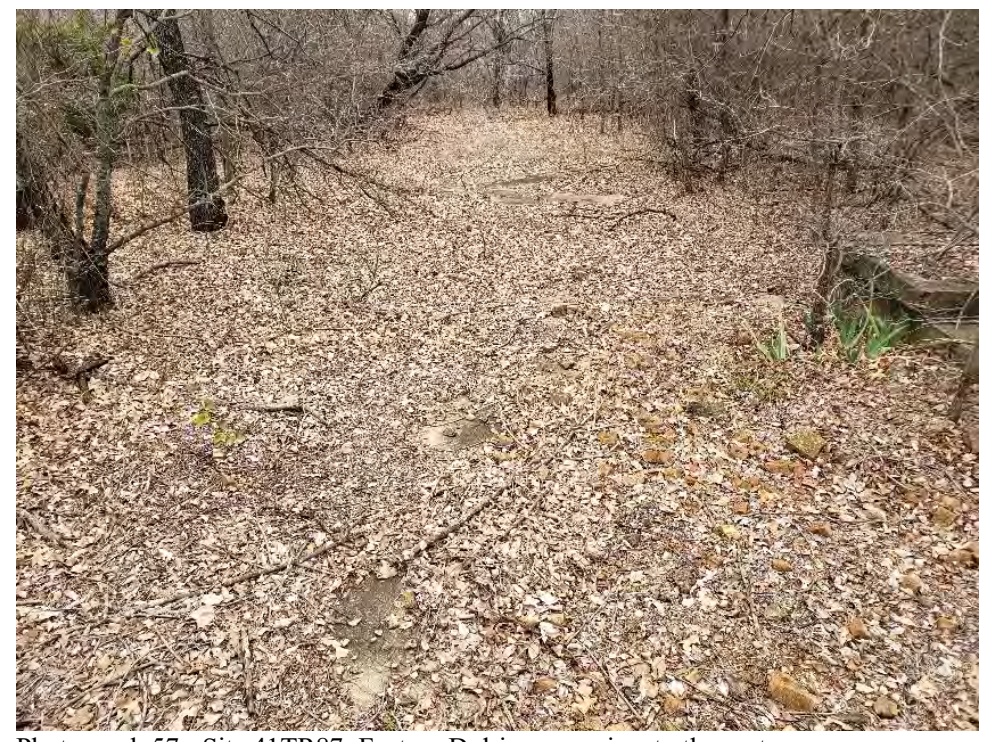

Photograph 57 - Site 41TR87: Feature D driveway, view to the east.

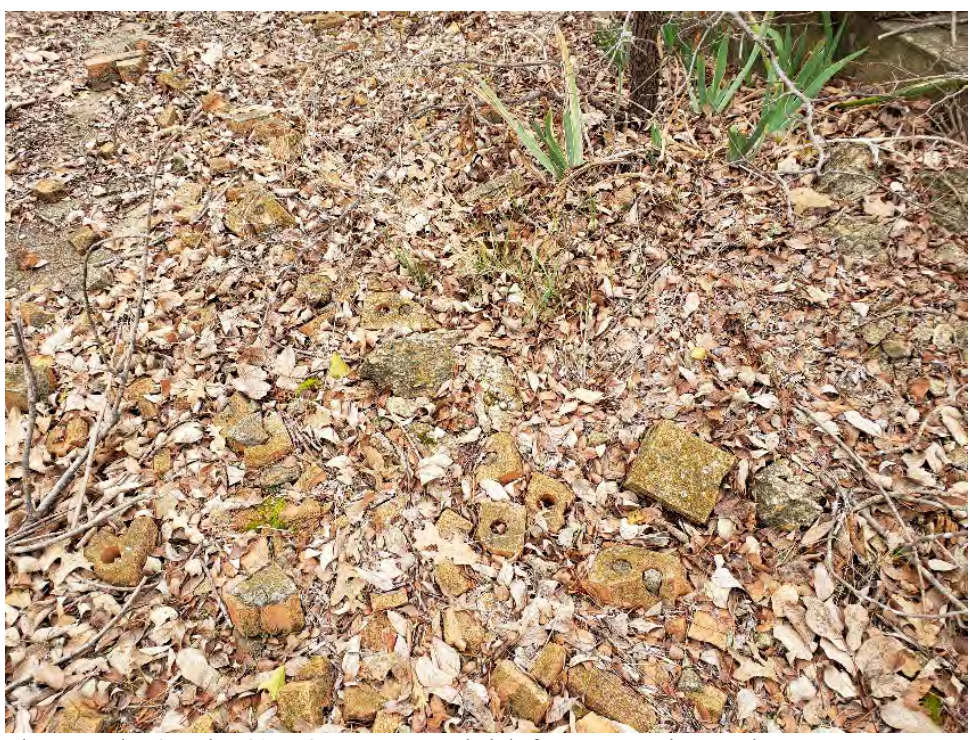

Photograph 59 - Site 41TR87: Feature D brick fragments, view to the east.
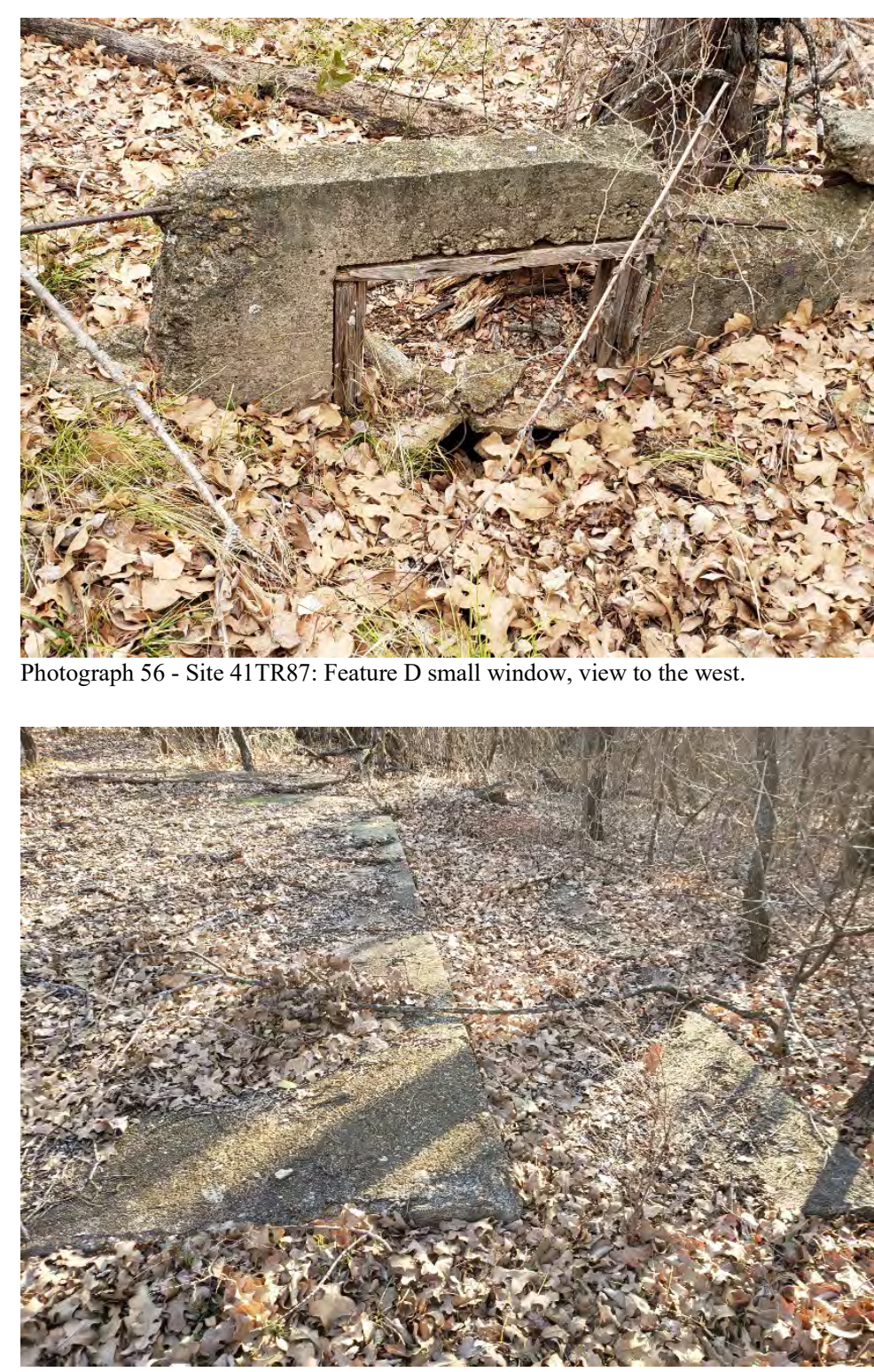

Photograph 58 - Site 41TR87: Feature D concrete slab, view to the south.

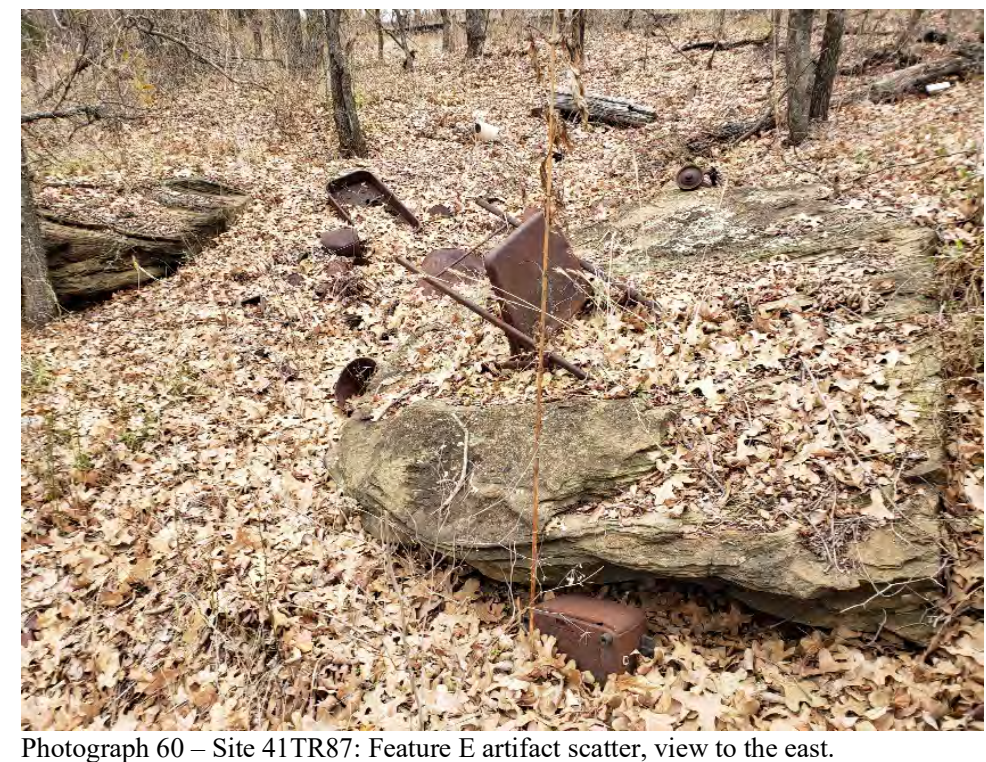




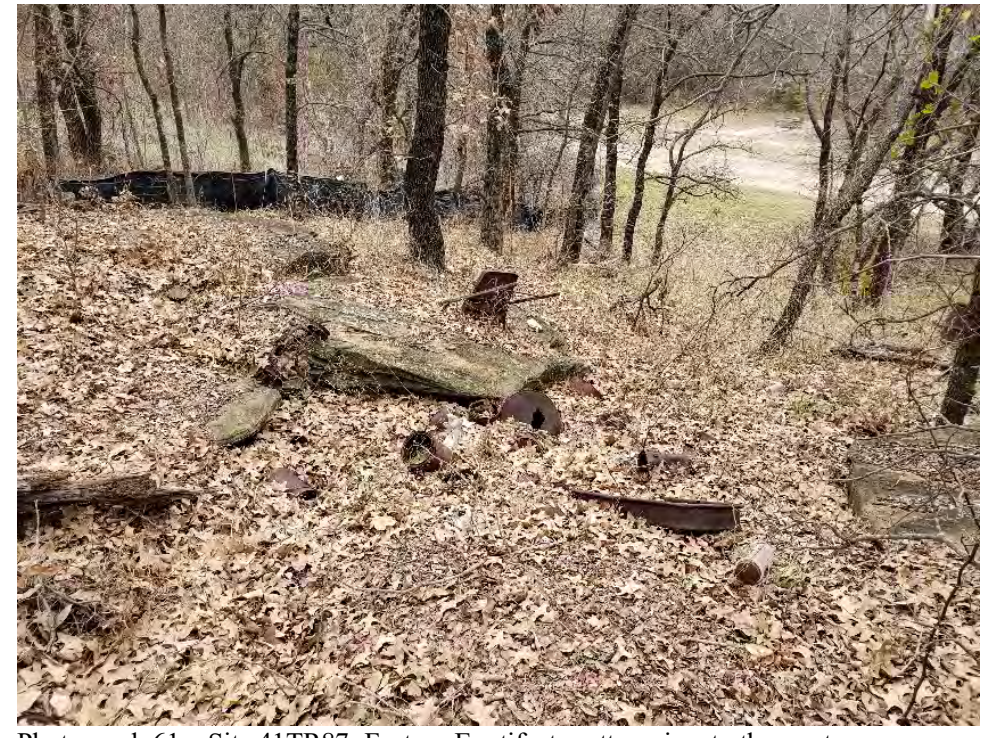
Photograph 61 - Site 41TR87: Feature E artifact scatter, view to the west.

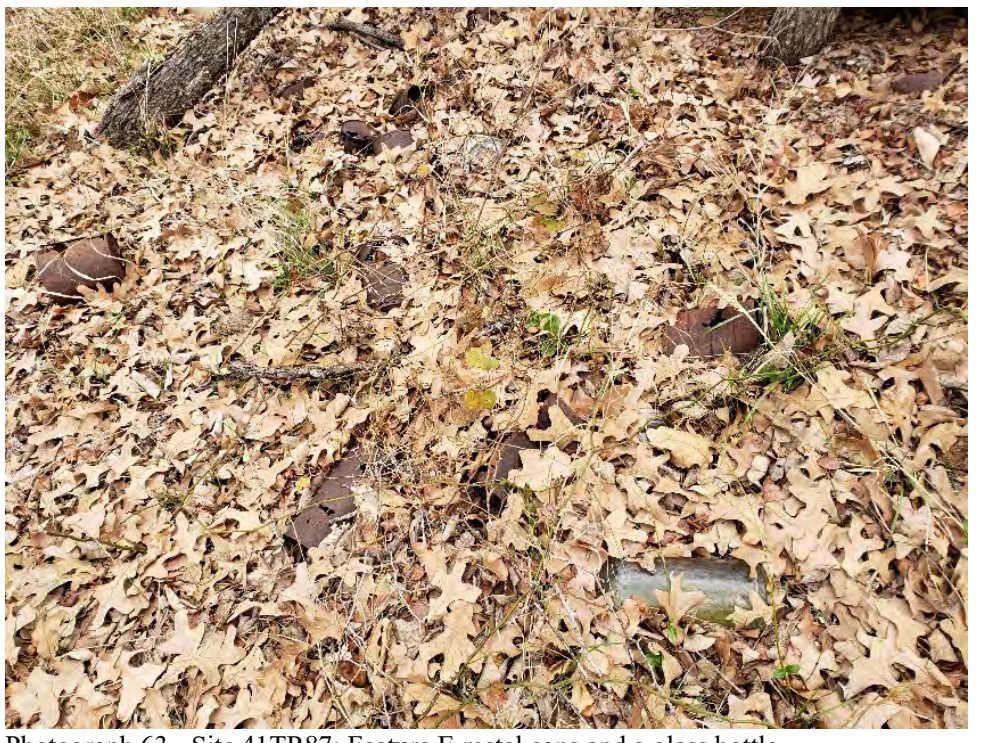
Photograph 63 - Site 41TR87: Feature E metal cans and a glass bottle.

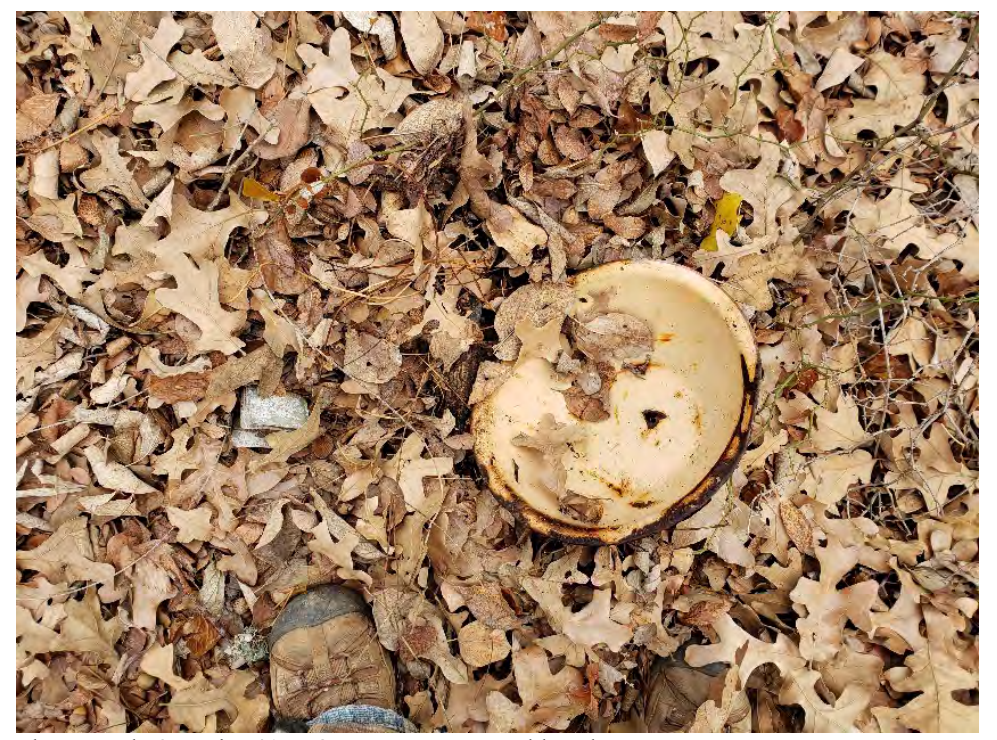

Photograph 65 - Site 41TR87: Feature E metal bowl

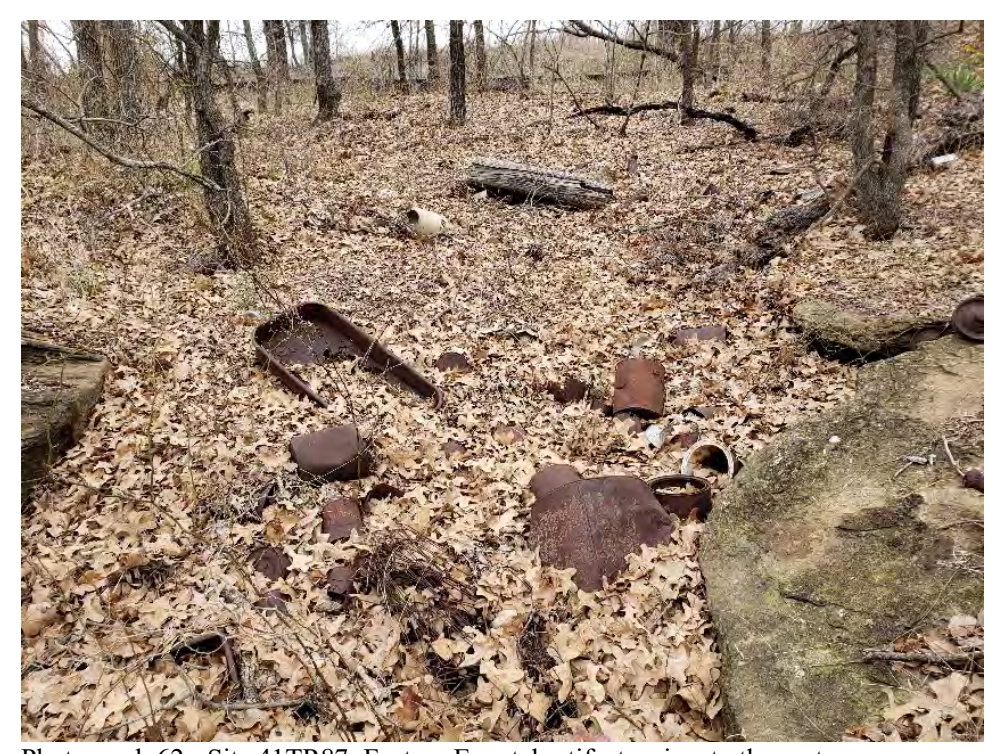

Photograph 62 - Site 41TR87: Feature E metal artifacts, view to the east.

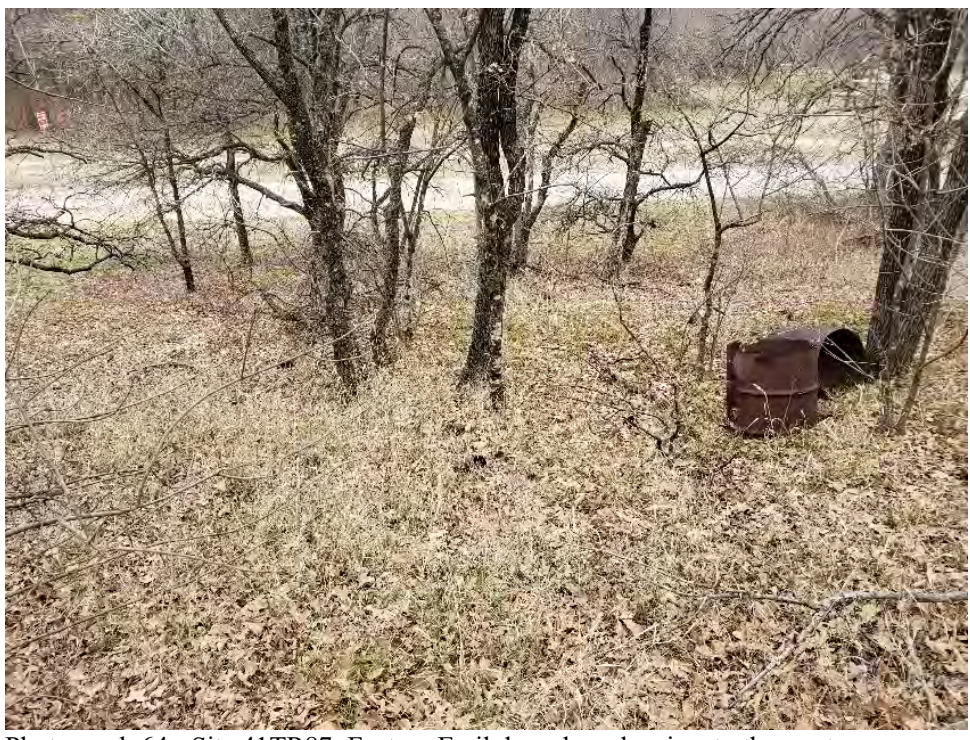

Photograph 64 - Site 41TR87: Feature E oil drum barrels, view to the west.

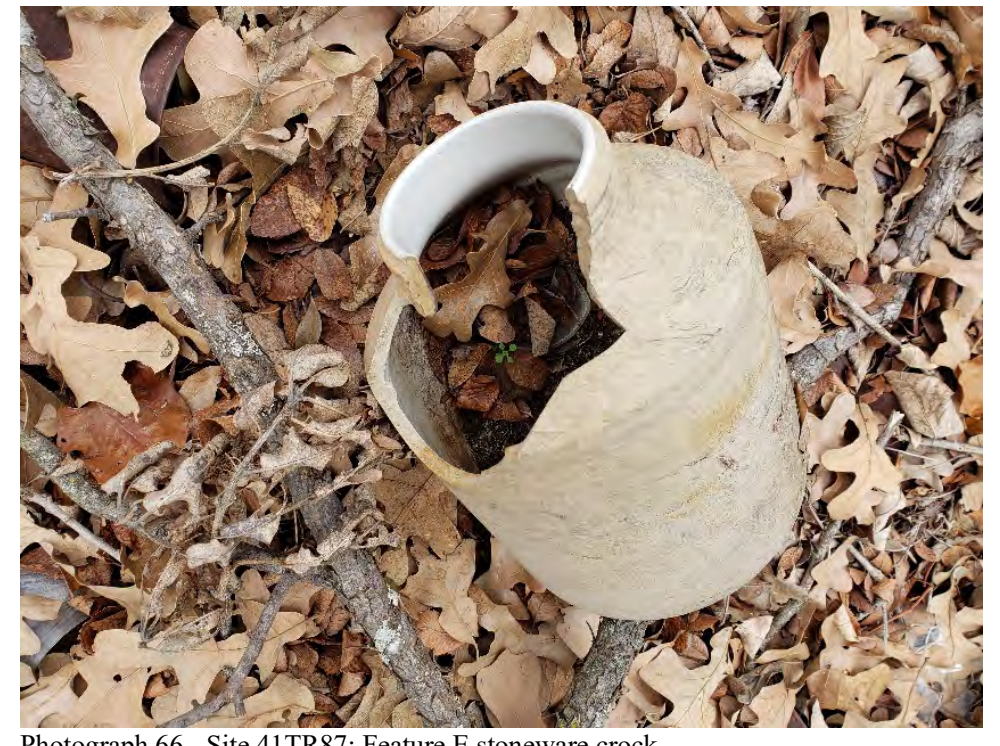

Photograph 66 - Site 41TR87: Feature E stoneware crock 


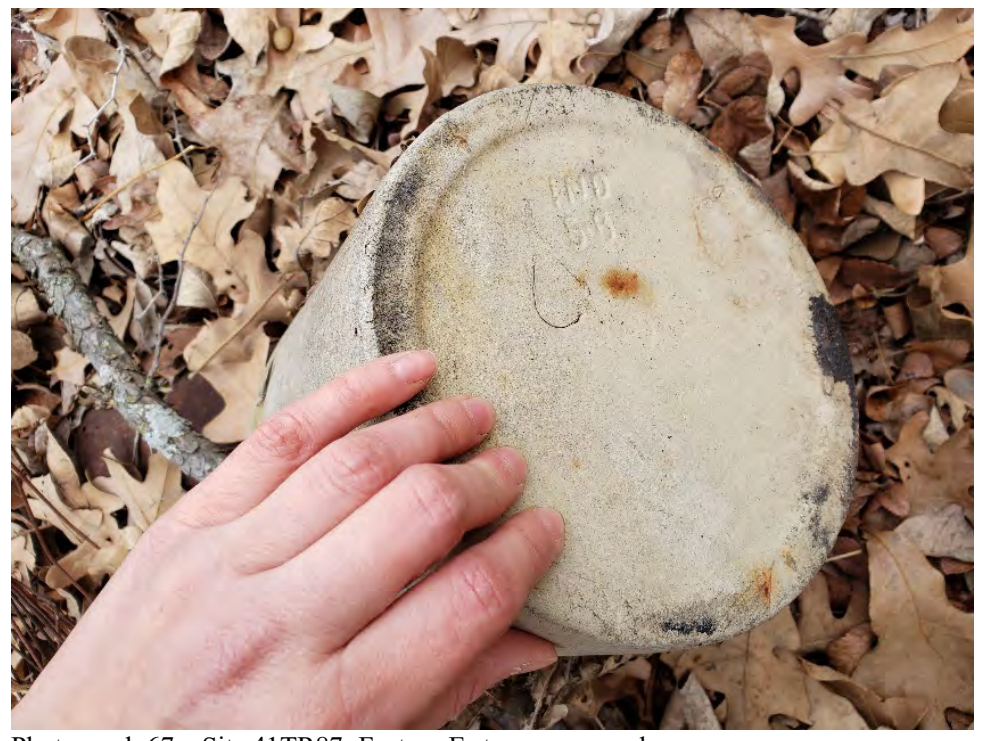

Photograph 67 - Site 41TR87: Feature E stoneware crock

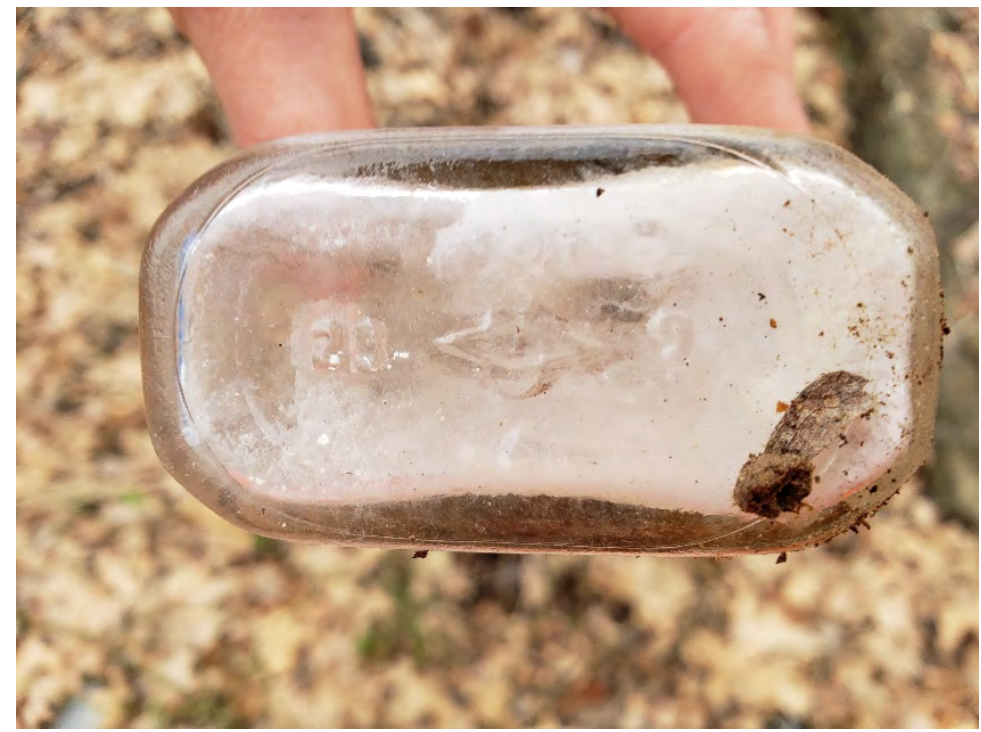

Photograph 69 - Site 41TR87: Feature E Owens-Illinois bottle

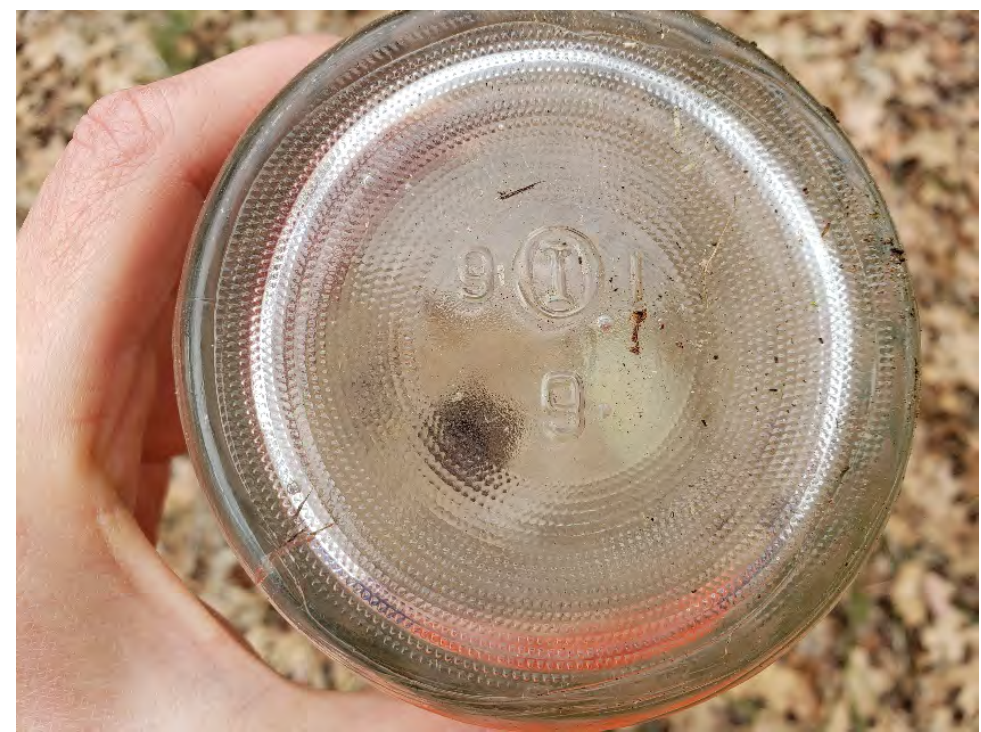

Photograph 71 - Site 41TR87: Feature E Owens-Illinois bottle

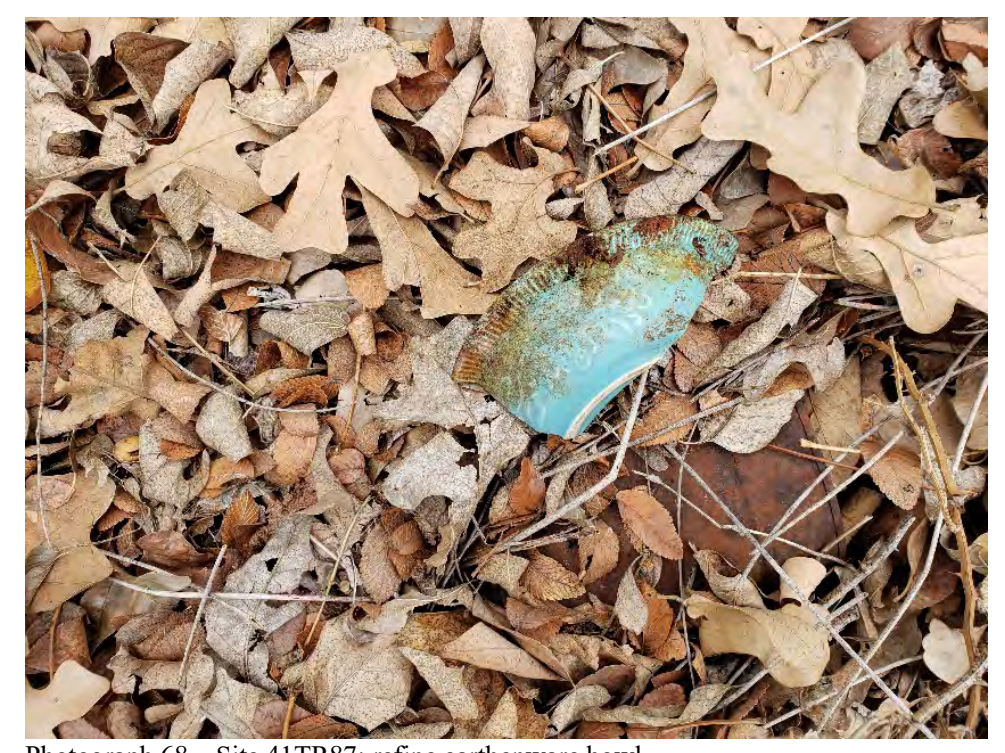

Photograph 68 - Site 41TR87: refine earthenware bowl

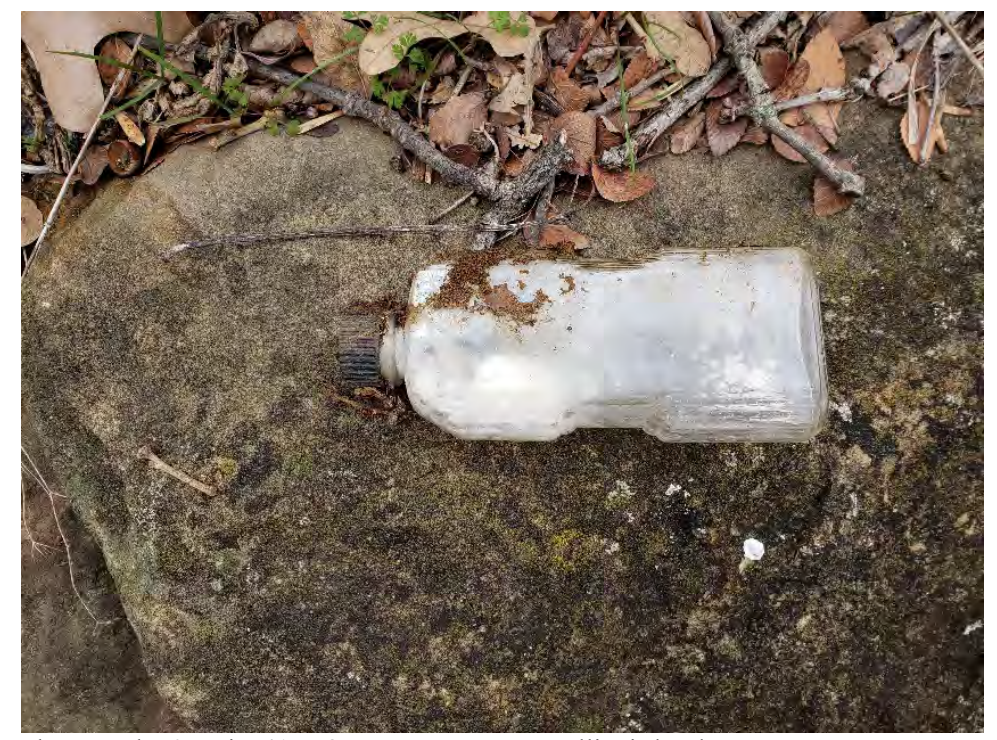

Photograph 70 - Site 41TR87: Feature E Owens-Illinois bottle

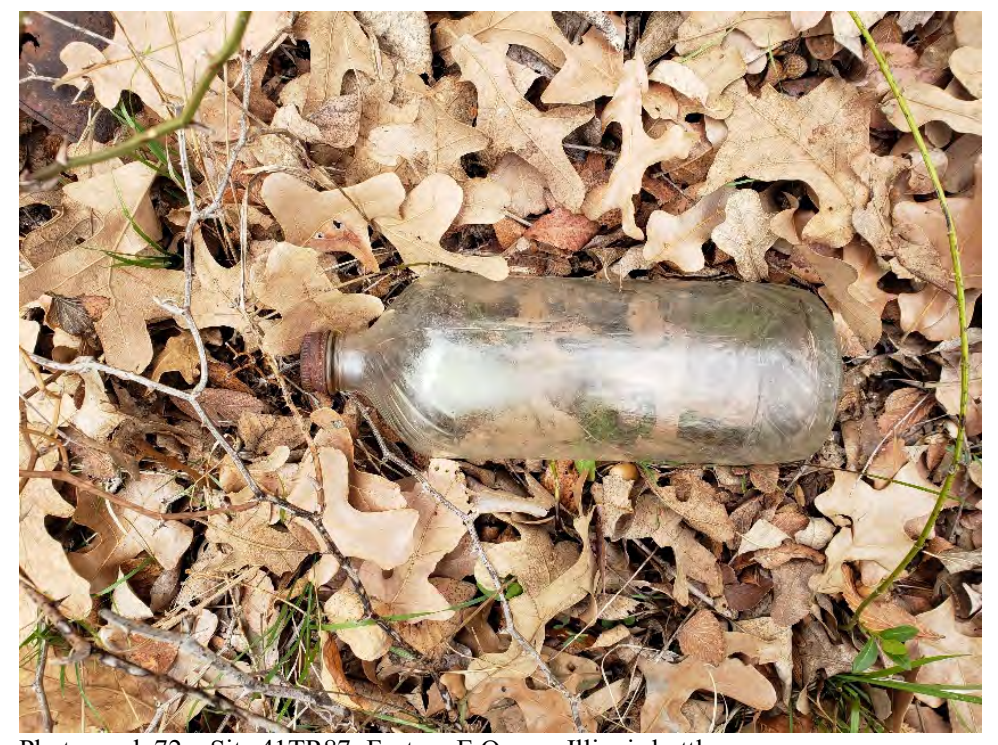

Photograph 72 - Site 41TR87: Feature E Owens-Illinois bottle 


\section{(n)

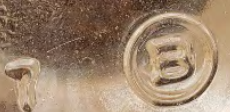

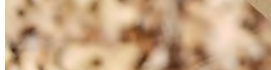

Photograph 73 - Site 41TR87: Feature E Brockway Glass Co. bottle

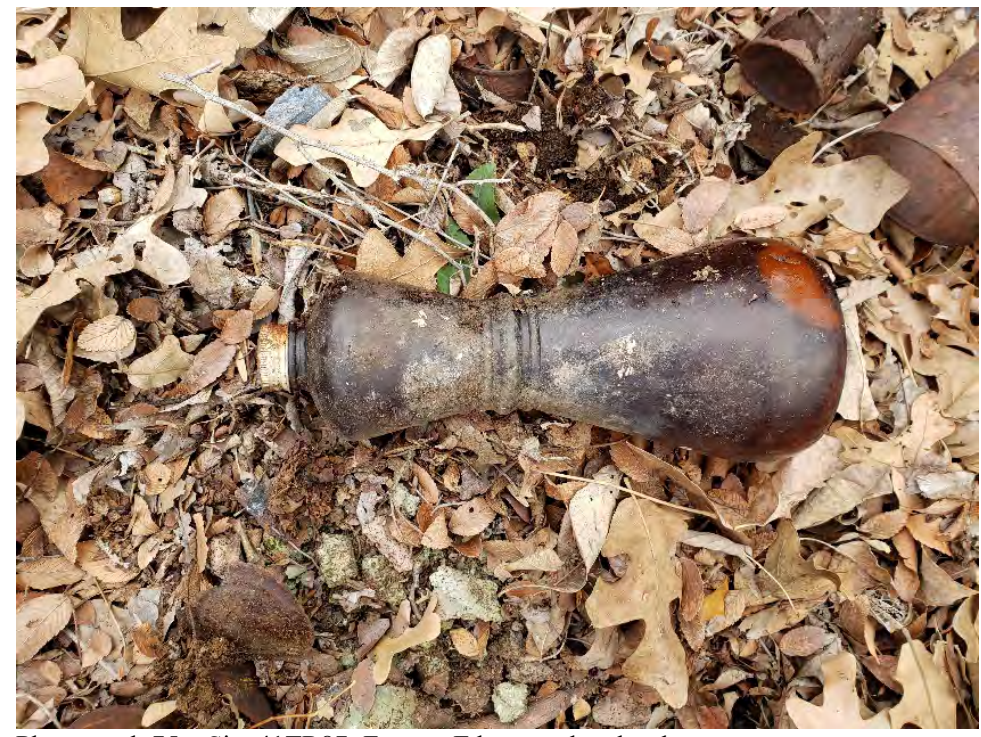

Photograph 75 - Site 41TR87: Feature E brown glass bottle

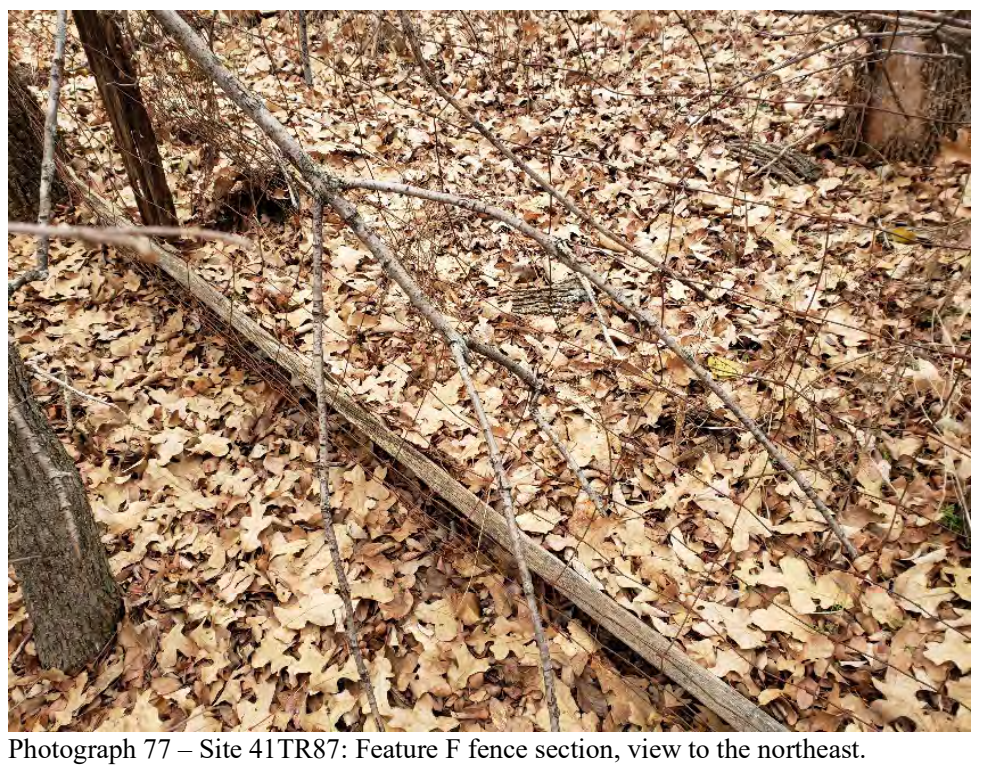

if

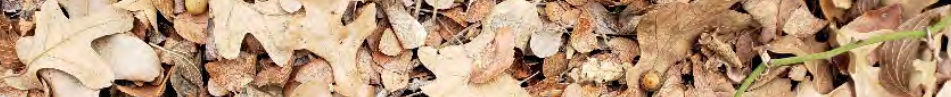

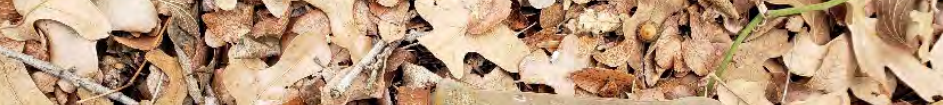

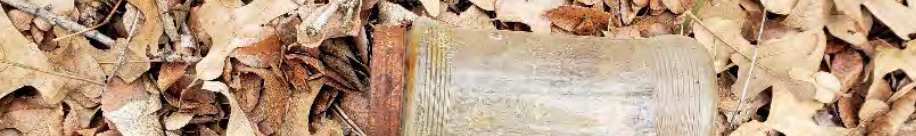

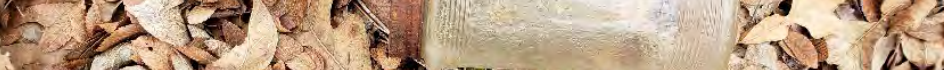

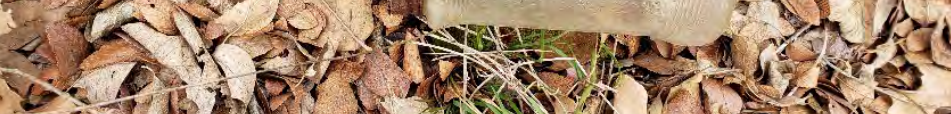

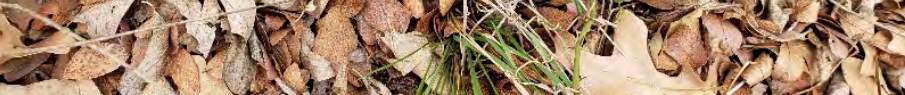

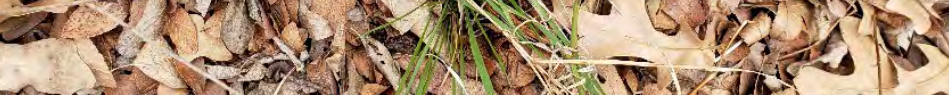

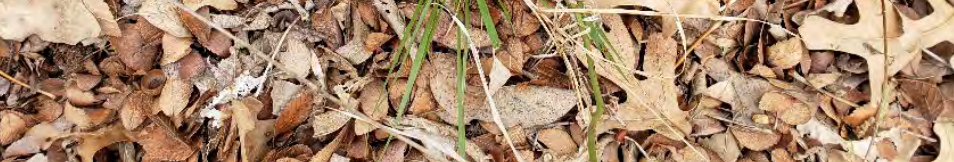

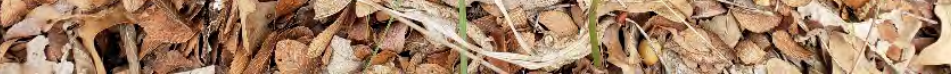
Photograph 74 - Site 41TR87: Feature E Brockway Glass Co. bottle

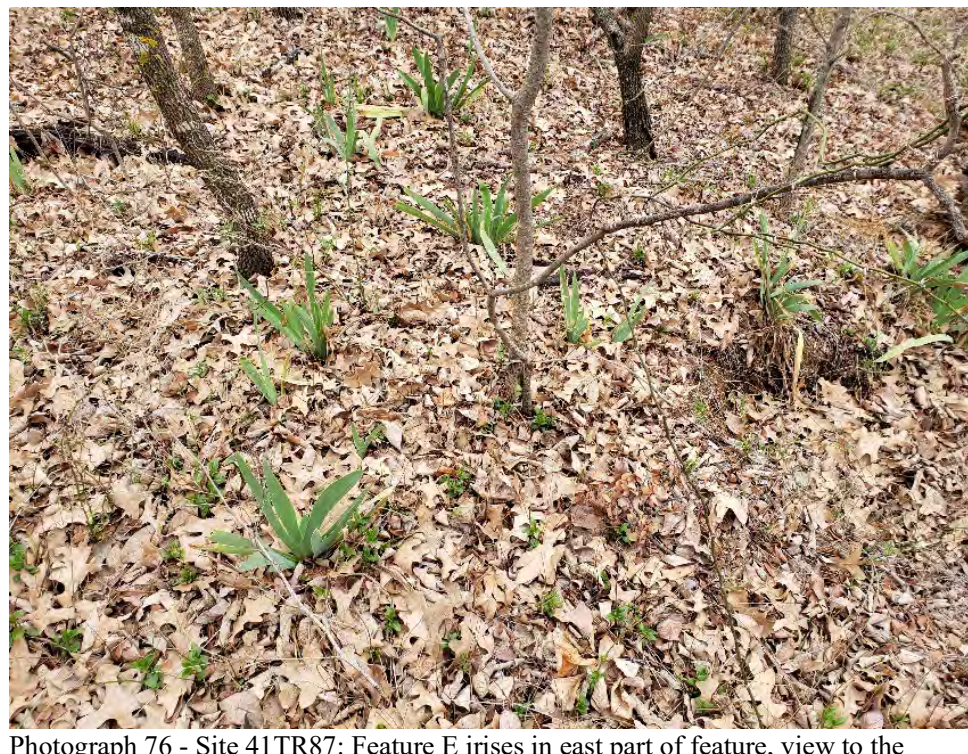
Photograph 76 - Site 41TR87: Feature E irises in east part of feature, view to the

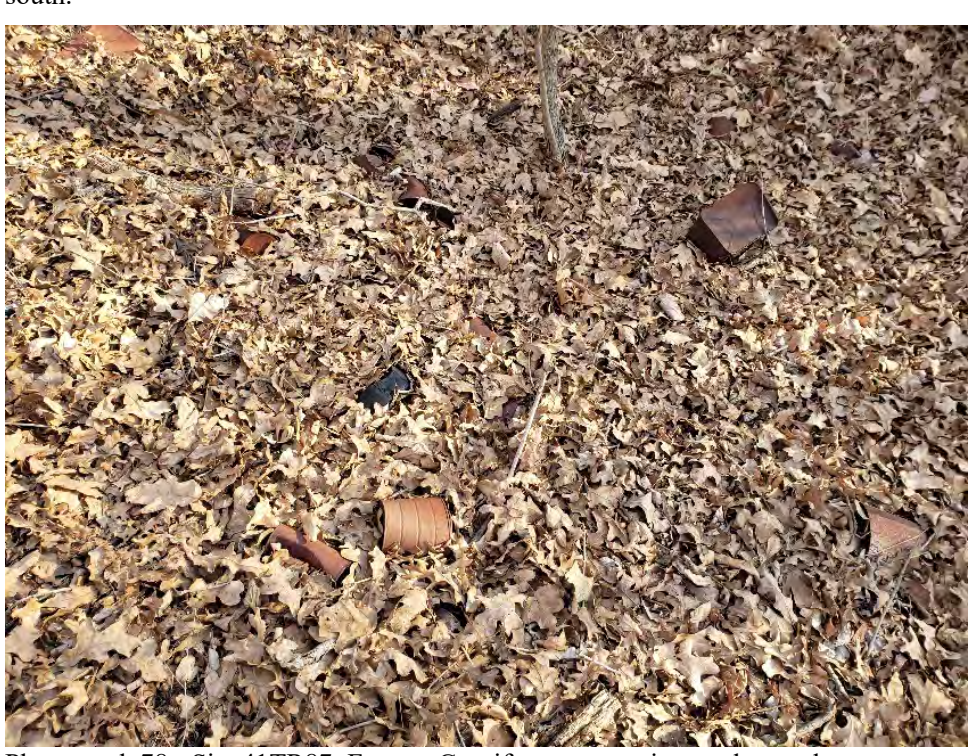
Photograph 78 - Site 41TR87: Feature G artifact scatter, view to the south. 


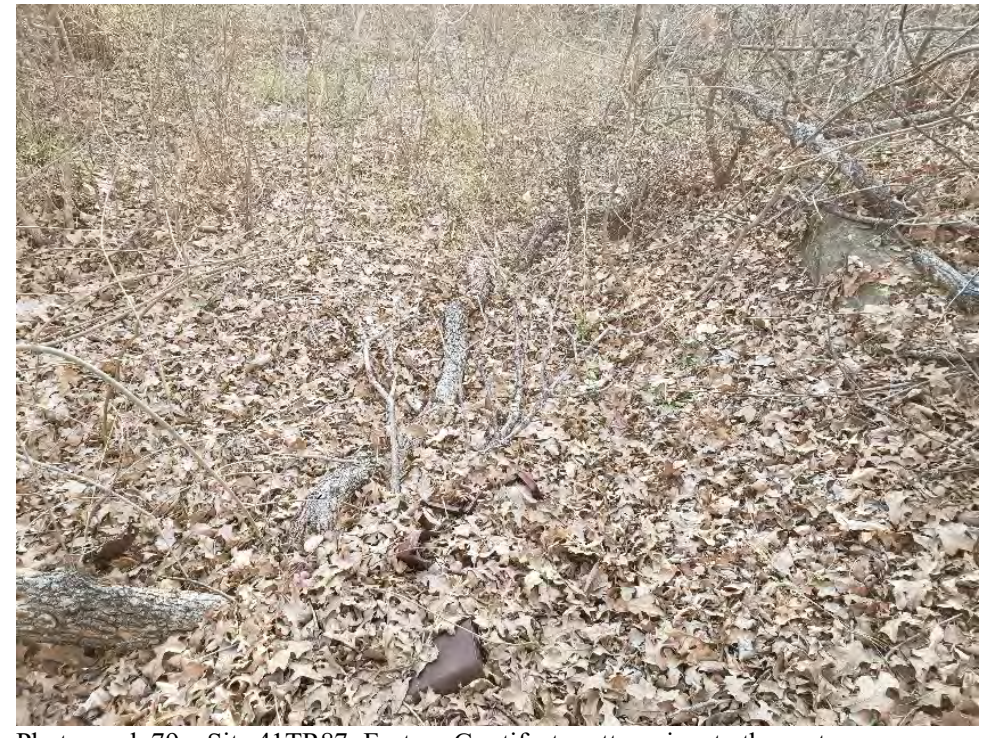

Photograph 79 - Site 41TR87: Feature G artifact scatter, view to the east.

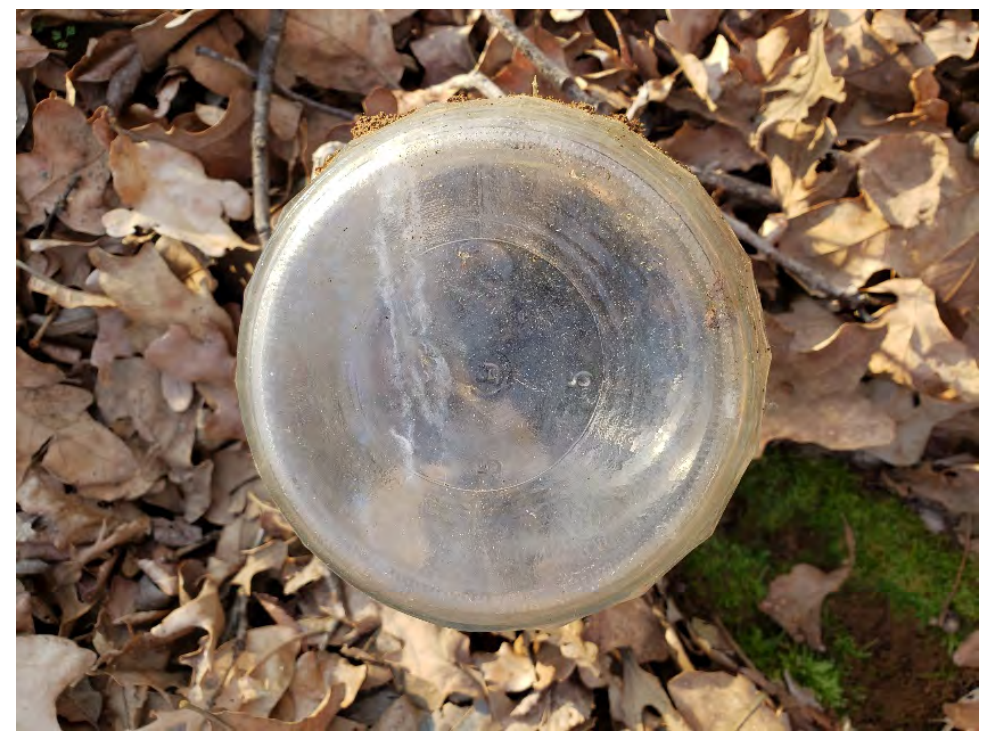

Photograph 81 - Site 41TR87: Feature G Brockway Glass Co. bottle

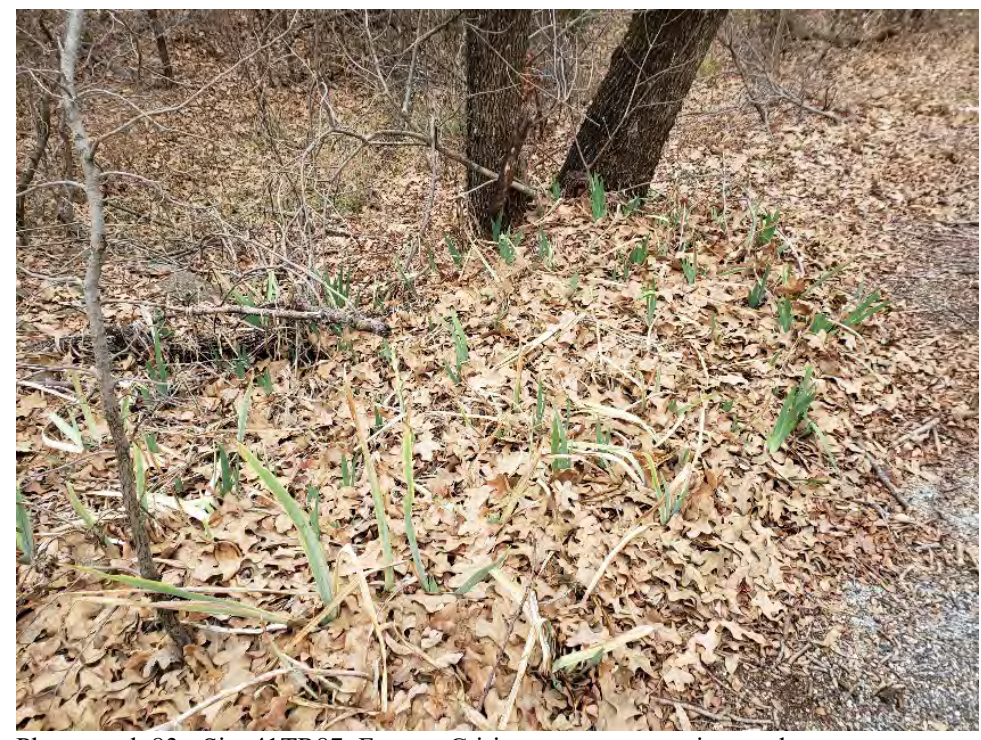

Photograph 83 - Site 41TR87: Feature G irises near scatter, view to the west

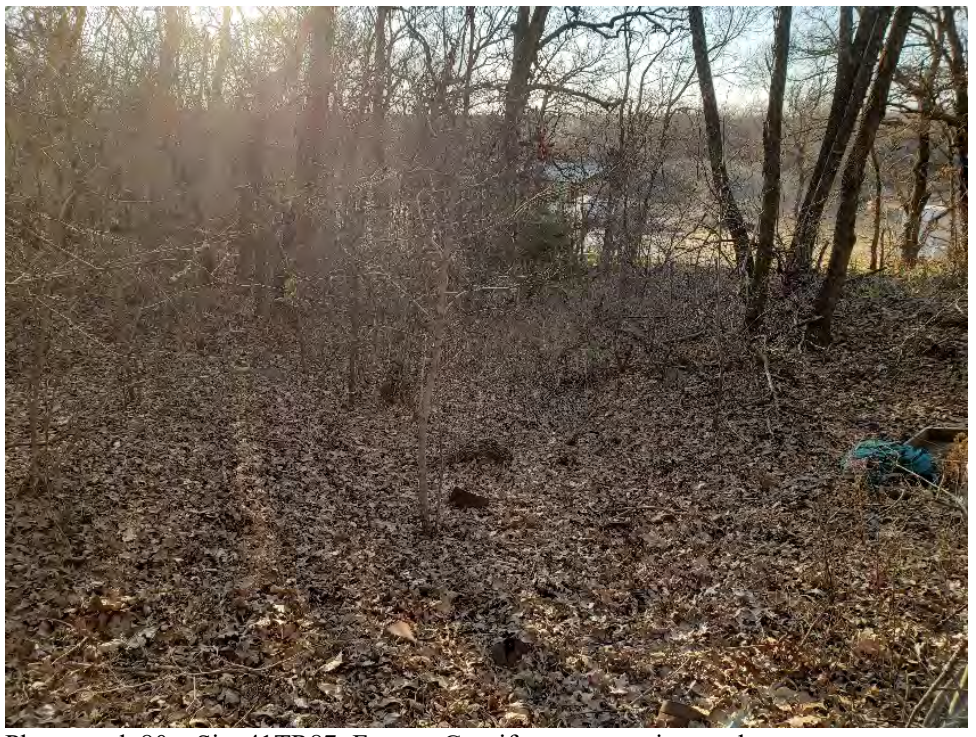

Photograph 80 - Site 41TR87: Feature G artifact scatter, view to the west.

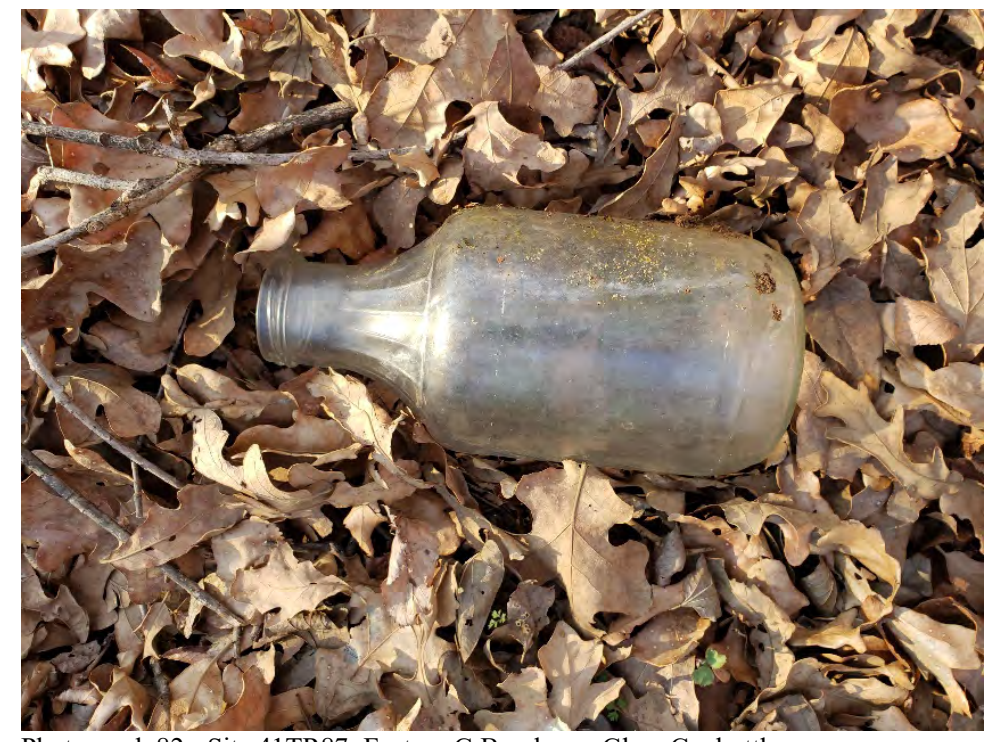

Photograph 82 - Site 41TR87: Feature G Brockway Glass Co. bottle 
This page intentionally left blank

DPS Outdoor Bomb and Gun Range Project

IES Project No. 03.006.081

Cultural Resources Survey Report 
APPENDIX B

Previous Agency Coordination 
This page intentionally left blank

DPS Outdoor Bomb and Gun Range Project

IES Project No. 03.006.081

Cultural Resources Survey Report 
This page has been removed intentionally to protect sensitive

\author{
cultural materials
}

Appendix C

Archeological Site Boundary Map 
This page intentionally left blank

DPS Outdoor Bomb and Gun Range Project

IES Project No. 03.006.081

Cultural Resources Survey Report 